US Army Corps

of Engineers ${ }_{\circledast}$

Engineer Research and

Development Center

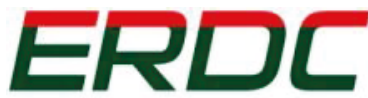

INNOVATIVE SOLUTIONS

for a safer, better world

Base Facilities Environmental Quality

\title{
Projection of Climate-Change Impacts on Army Installation Energy Use
}

James P. Miller, Isabel H. Kim, and David M. Underwood

June 2018

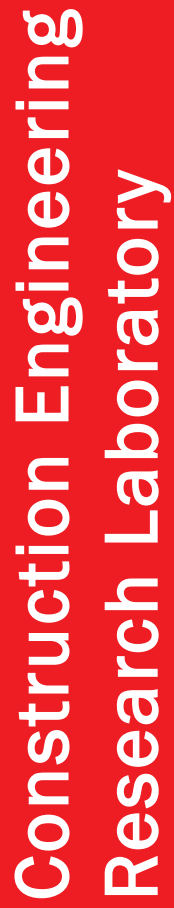

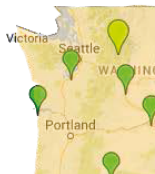

Northwest

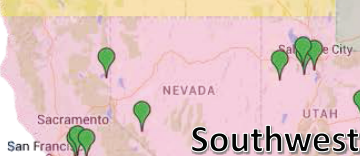

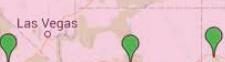

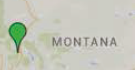

N. Great Plains
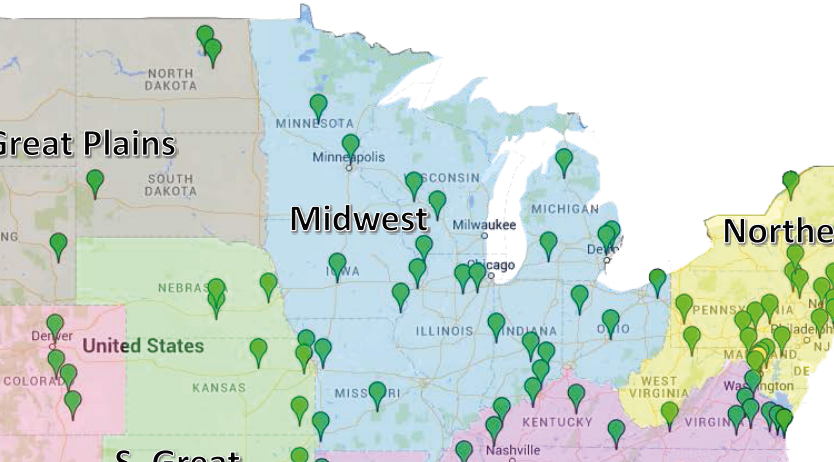

Northeast
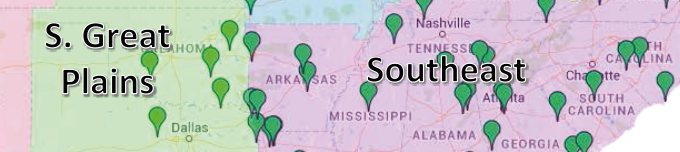
The U.S. Army Engineer Research and Development Center (ERDC) solves the nation's toughest engineering and environmental challenges. ERDC develops innovative solutions in civil and military engineering, geospatial sciences, water resources, and environmental sciences for the Army, the Department of Defense, civilian agencies, and our nation's public good. Find out more at www.erdc.usace.army.mil.

To search for other technical reports published by ERDC, visit the ERDC online library at http://acwc.sdp.sirsi.net/client/default. 


\section{Projection of Climate-Change Impacts on Army Installation Energy Use}

James P. Miller, Isabel H. Kim, and David M. Underwood

Construction Engineering Research Laboratory

U.S. Army Engineer Research and Development Center

2902 Newmark Drive

Champaign, IL 61822

Final Report

Approved for public release; distribution is unlimited.

Prepared for Office of the Assistant Secretary of the Army for Acquisition, Logistics, and Technology (ASA(ALT)

103 Army Pentagon

Washington, DC 20314-1000

Under Project A1160-FY15, “Integrated Climate Assessment for Army Enterprise Planning"; P2 402188, "Ability to Expand" 


\section{Abstract}

Army installations depend on a secure, reliable, and abundant supply of energy in order to accomplish their missions. As the range of Army activities has become increasingly complex, the Army's dependence on energy has grown accordingly. Simultaneously, the Army has experienced growing pressure to reduce its energy consumption. In addition, environmental concerns and federal mandates introduce added incentives to minimize installation energy consumption.

Because energy is such an essential support to the Army's mission and a significant element of the Army budget, when performing Army stationing analyses, it is appropriate to consider potential climate change implications on installations' energy usage.

This report documents research conducted from Fiscal Year 2014 (FY14), FY15, and FY16 that addresses how potential climate changes might affect Army installations from an energy perspective, with emphasis on how an installation's energy consumption might be projected to change as a result.

DISCLAIMER: The contents of this report are not to be used for advertising, publication, or promotional purposes. Citation of trade names does not constitute an official endorsement or approval of the use of such commercial products. All product names and trademarks cited are the property of their respective owners. The findings of this report are not to be construed as an official Department of the Army position unless so designated by other authorized documents. 


\section{Contents}

Abstract.................................................................................................................................. if

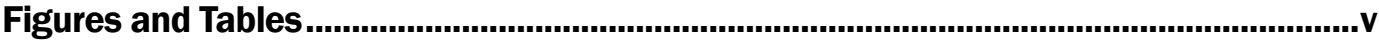

Preface

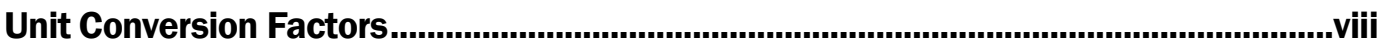

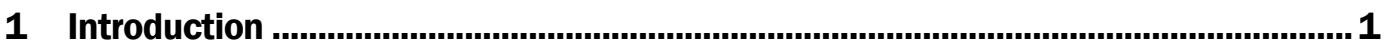

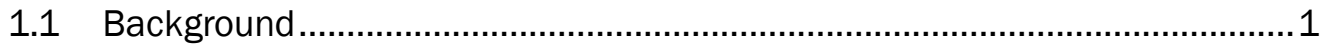

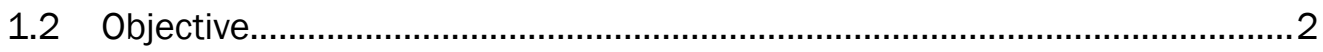

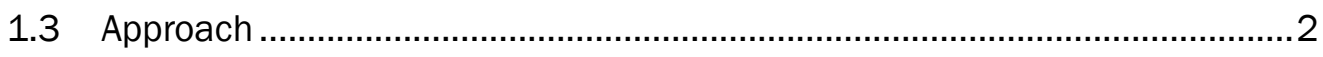

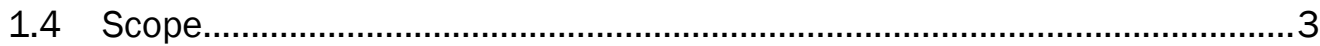

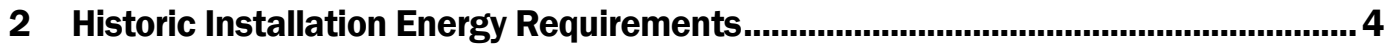

2.1 Energy utilization overview.................................................................. 4

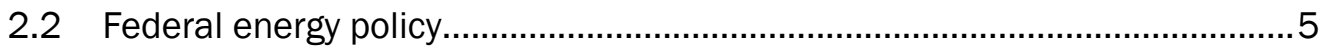

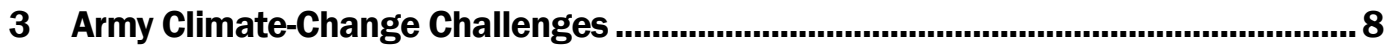

3.1 Climate change trends and model projections........................................... 8

3.2 DoD and Army responses to climate change ............................................... 9

3.3 General implications for Army planning and operations ..............................11

3.4 Specific implications for the Army ........................................................ 12

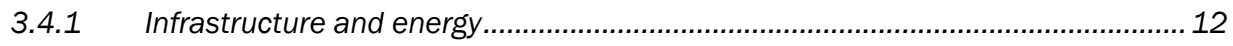

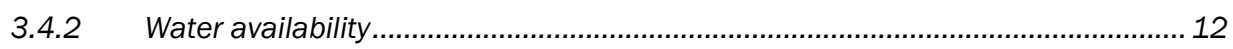

3.4.3 Threatened and endangered species ............................................................... 12

3.4.4 Climate-aggravated training impacts.................................................................. 13

3.4.5 Climate-dependent noise propagation .............................................................. 13

3.4.6 Urban growth and encroachment ...................................................................... 13

3.5 Regional climate change implications................................................... 13

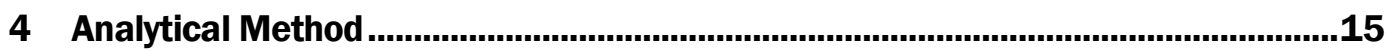

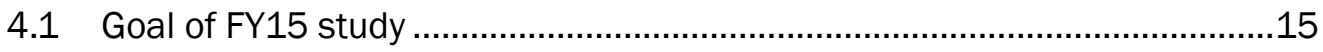

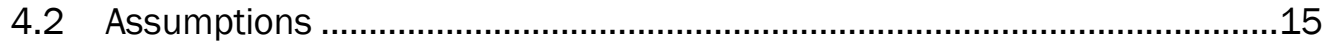

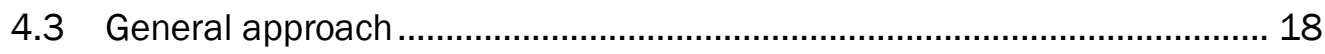

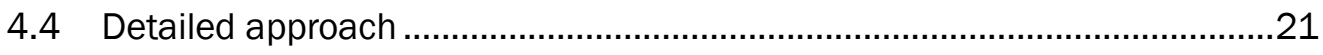

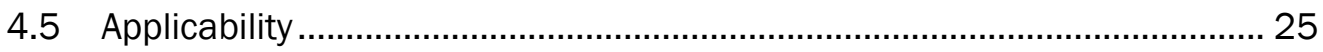

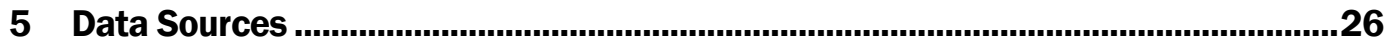

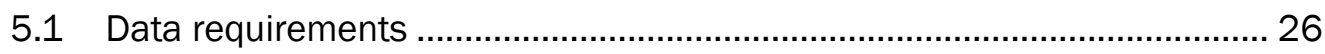

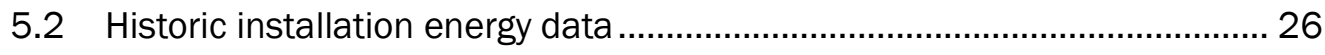

5.2.1 Purchased utilities consumption data .................................................................. 26

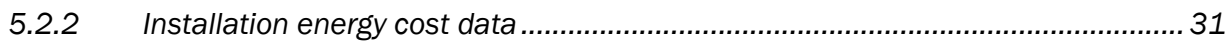

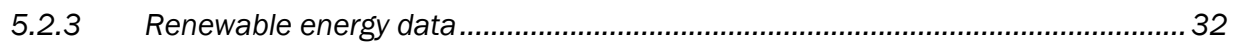


5.3 Historic installation square footage data ................................................. 33

5.4 Historic installation weather data............................................................ 35

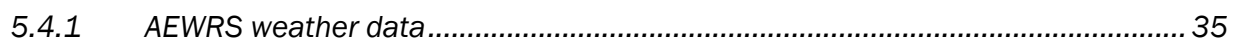

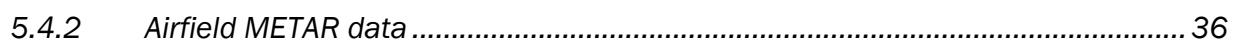

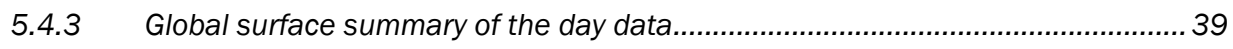

5.5 Projected installation monthly average temperature data..........................41

5.6 Historic installation population data ...................................................... 46

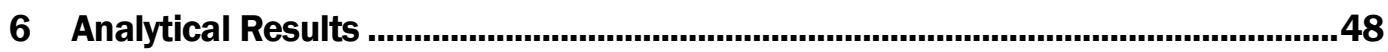

6.1 Selection of demonstration installations ................................................. 48

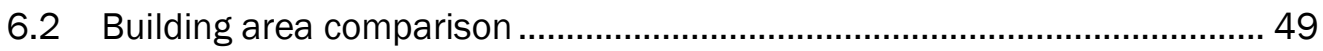

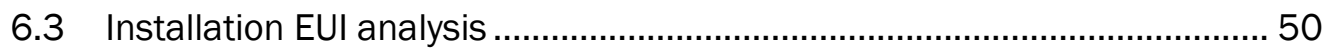

6.4 Projecting climate change impacts on future energy consumption ...............57

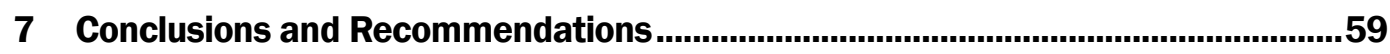

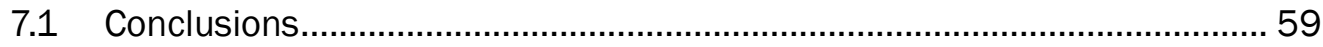

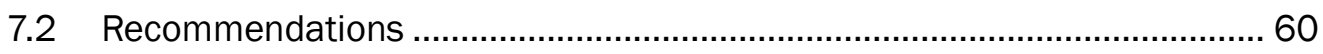

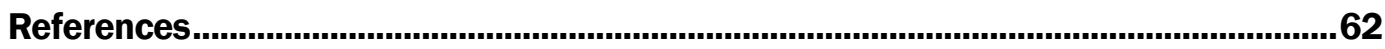

Appendix A: Impact of Climate Change on Renewable Energy Potential ....................66

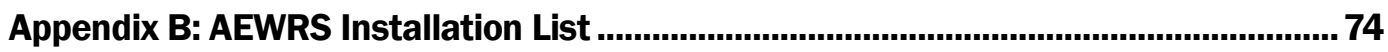

Appendix C: Accessing Historic GSOD Weather Data .................................................79

Appendix D: Projected Climate Change Impacts on Installations' Energy

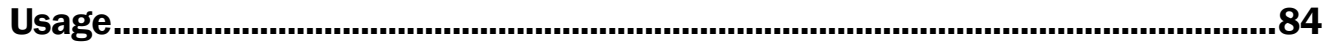




\section{Figures and Tables}

\section{Figures}

Figure 1. Slide from DASA E\&S presentation "Army Energy and Sustainability Program.".

Figure 2. Roadmap of Army efforts to comply with Federal energy and

sustainability policies.

Figure 3. Campus hourly electric demand versus outdoor dry bulb temperature for both occupied and unoccupied times.

Figure 4. Notional plot of monthly EUI vs monthly average temperature...........................21

Figure 5. Monthly EUI plotted against monthly average temperature..................................22

Figure 6. Monthly EUls vs monthly average temperature for natural gas, propane and electricity at a "typical" installation.

Figure 7. Projected monthly EUI (by resource type) vs projected monthly mean ambient temperatures for a notional installation.

Figure 8. Image of AEWRS Utilities screen showing monthly energy consumption data by product type for Fort Carson.

Figure 9. Two years of reported building energy data for Fort Bliss.

Figure 10. Image of AEWRS Renewables screen showing renewable energy resources for Fort Carson.

Figure 11. Image of AEWRS Square Footage screen showing square footage data for Fort Carson facilities.

Figure 12. Fort Carson square footage data as reported in AEWRS.

Figure 13. Image of AEWRS Weather Data screen showing monthly heating degree days and cooling degree days for Fort Carson facilities............................................36

Figure 14. Sample of GSOD data for Fort Hood from April 1 to May 1, 2015....................40

Figure 15. Global Summary of the Day (GSOD) on NNDC Climate Data Online.

Figure 16. Projected daily maximum temperatures $\left[{ }^{\circ} \mathrm{C}\right]$ for thirteen selected installations.

Figure 17. Projected daily minimum temperatures $\left[{ }^{\circ} \mathrm{C}\right]$ for thirteen selected installations.

Figure 18 All forcing agents' atmospheric $\mathrm{CO}_{2}$-equivalent concentrations (in

parts-per-million-by-volume (ppmv)) according to four RCPs.

Figure 19. Image of ASIP database search screen showing population data from Fort Carson for FY2007 to FY2013.

Figure 20. Image of an exported ASIP population file for Fort Carson.

Figure 21. ASHRAE/IECC climate zones map showing approximate locations of

Fort Bliss, Fort Bragg, Fort Carson, Fort Riley, and Fort Sill.

Figure 22. Changes in conditioned building area at Fort Bliss, Fort Bragg, Fort Carson, Fort Riley, and Fort Sill.

Figure 23. Fort Bliss monthly average temperature, December 2013 to March 2015. 
Figure 24. Fort Bliss total monthly energy consumption, December 2013 to March 2015

Figure 25. Fort Bliss monthly energy cost, December 2013 to March 2015

Figure 26. Plot of Fort Bliss Monthly EUI vs monthly average temperature for Jan 2006 to Dec 2015.

Figure 27. Plot of Fort Bliss monthly EUI vs historic monthly average temperature for the period Dec 2013 to Mar 2015.

Figure 28. Fort Bliss EUI data plotted in two-year increments.

Figure 29. Projected monthly average temperatures for Fort Bliss based on the CCSM4 GCM at an RCP of 8.5.

Figure 30. Projected monthly EUI vs projected monthly average temperatures 56

Figure 31. Graph of projected mean annual EUI (MMBTU/kSF/year) for Five Installations from 2020 to 2050.

\section{Tables}

Table 1. U.S. regional variations in climate-change impacts. ................................................14

Table 2. Presentation format of results of this analysis for Installation X..........................20

Table 3. AEWRS utility product codes, reporting units and BTU content. ............................27

Table 4. Energy products types reported in the AEWRS Database for 49 major

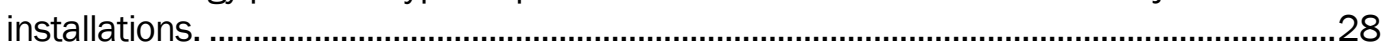

Table 5. Fort Bragg energy cost data reported in AEWRS for March 2015........................31

Table 6. GCM models and RCPs used to project monthly average temperature

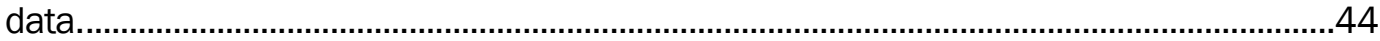

Table 7. Current form of projected annual EUI time series tabular output. ..........................45

Table 8. Updated form of projected annual EUI time series tabular output. ......................45

Table 9. Projected mean annual EUI (MMBTU/kSF/year) for Five Installations

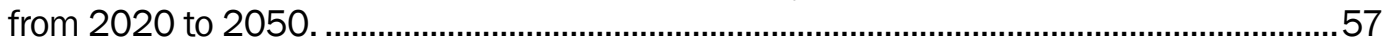

Table 10. Portrayal of projected annual EUI for Fort Bliss at 5-year intervals. .....................58 


\section{Preface}

This study was conducted for the Office of the Assistant Secretary of the Army for Acquisition, Logistics, and Technology (ASA(ALT)) under Research, Development, Test, and Evaluation Program Element 62272889600 A896, "Base Facilities Environmental Quality”; Project A116o-FY15, "Integrated Climate Assessment for Army Enterprise Planning”; P2 402188, "Ability to Expand” The technical monitor was Alan B. Anderson (CEERD-CZT).

The work was performed by the Energy Branch of the Installations Division (CEERD-CFE), U.S. Army Engineer Research and Development Center, Construction Engineering Research Laboratory (ERDC-CERL). At the time of publication, Giselle Rodriguez was Chief, CEERD-CFE; Donald $\mathrm{K}$. Hicks was Chief, CEERD-CN; and Alan B. Anderson, CEERD-CZT, was the Technical Director for Environmental Quality/Sustainable Lands and Ranges. The Interim Deputy Director of ERDC-CERL was Michelle J. Hanson and the Interim Director was Dr. Kirankumar Topudurti.

The Commander of ERDC was COL Bryan S. Green and the Director was Dr. David W. Pittman. 


\section{Unit Conversion Factors}

\begin{tabular}{|l|l|l|}
\hline Multiply & By & To Obtain \\
\hline British thermal units (International Table) & $1,055.056$ & joules \\
\hline cubic feet & 0.02831685 & cubic meters \\
\hline degrees Fahrenheit & $(\mathrm{F}-32) / 1.8$ & degrees Celsius \\
\hline gallons (U.S. liquid) & $3.785412 \mathrm{E}-03$ & cubic meters \\
\hline horsepower (550 foot-pounds force per second) & 745.6999 & watts \\
\hline inches & 0.0254 & meters \\
\hline miles per hour & 0.44704 & meters per second \\
\hline miles (U.S. statute) & $1,609.347$ & meters \\
\hline square feet & 0.09290304 & square meters \\
\hline square miles & $2.589998 \mathrm{E}+06$ & square meters \\
\hline tons (2,000 pounds, mass) & 907.1847 & kilograms \\
\hline
\end{tabular}




\section{Introduction}

\subsection{Background}

Army installations depend on a secure, reliable, and abundant supply of energy in order to accomplish their missions. Energy delivered to Army installations in the right forms and sufficient quantities when needed is necessary to support the full range of Army activities, from tactical operations to maintenance of comfort conditions in Army facilities. No Army installation can function effectively without ready, reliable access to the energy required to meet their missions.

As the range of Army activities has become increasingly complex, the Army's dependence on energy has grown accordingly. Simultaneously, the Army has experienced growing pressure to decrease its energy consumption in order to reduce costs and comply with increasingly stringent government emission mandates.

The Army is regularly faced with stationing decisions about locating or relocating Army forces and activities to optimally maximize its capabilities while minimizing overall costs. In addition to ongoing stationing decisions, the Army periodically performs Base Realignment and Closure (BRAC) analyses that can entail large-scale reshaping of the Army's inventory of installations and associated activities.

Because energy is a critical input to the Army's mission and a significant element of the Army budget, stationing analyses now must consider potential climate-change implications for installation energy use. If climate change generally results in warmer temperatures, installations in coolingdominated locations would be expected to face increased cooling loads and, possibly, reduced heating loads. The impact of such changes would probably be an increase in electrical (cooling) requirements and possibly a reduction in fossil fuel (heating) requirements. Installations in heatingdominated areas might be expected to experience reduced heating requirements along with a possible increase in cooling requirements.

Also, as installations experience changes in their relative cooling energy and heating energy requirements, they will likely see a corresponding effect on their utility costs. Assuming, for example, that an installation saw a 
decrease in its heating energy requirements and a comparable increase in its cooling energy requirements, the installation would probably experience an overall increase in its utility costs because the currently dominant cooling-energy source (electricity) is much more expensive in terms of dollars per million British Thermal Units (\$/MMBTU) than the currently dominant heating-energy source (natural gas).

The impacts of climate change on installation energy consumption have become an important consideration in Army analysis and planning. Studies performed by the U.S. Army Engineer Research and Development Center, Construction Engineering Research Laboratory (ERDC-CERL) have developed a method to help forecast installation energy consumption for use in various Army analysis and planning activities.

\subsection{Objective}

This report documents studies performed from FY14 through FY16 that address how potential climate changes might affect Army installations from an energy perspective; specifically, to investigate how an installation's energy consumption might be projected to change as a result of climate change.

\subsection{Approach}

In FY14 the research team performed a study focusing on climate change effects on installation energy availability, energy security, and the ability to develop renewable energy resources. That study (Miller et al. 2015) took a high-level view of how climate change might affect Army installations from an energy perspective, and was useful for identifying the entire trade space to be considered and assisted in seeing which issues were most readily addressed and which issues to focus on in follow-on work. The present report presents the results of the FY15 and FY16 work.

In FY15, emphasis was narrowed to the possible impacts of climate change on installation energy consumption and overall energy costs. The investigation developed a methodology to relate historic local temperature data to historic installation energy usage. The historic energy usage was analyzed according to energy source (e.g., electricity, natural gas, propane, fuel oil, etc.) with attention to the historic consumption of each utility type based on monthly average ambient temperature. In order to account for changes in the historic installation building inventory over time, energy 
usage was normalized by determining historic energy use intensity (EUI), measured in millions of BTUs per thousand square feet (MMBTU/kSF) of conditioned building space. For each utility type, a relationship between monthly EUI and historic monthly average temperature was derived. These relationships were then combined with projections of future monthly average ambient temperatures at intervals of 10, 20,30, and 40 or more years into the future to project changes in the EUI for the individual utility types. Upon establishing projected EUIs for each energy source at each future time interval, it becomes possible to project consumption of each utility type and overall installation utility costs at these future points in time.

During FY16, the methodology developed in FY15 was refined and extended. Algorithms were developed for analyzing the available historic installation utilities data, square footage data, and weather data. Projected climate data were then incorporated to provide insight into how installation energy consumption may be expected to change as a result of climate changes.

\subsection{Scope}

This study is limited to consideration of the probable energy-consumption impacts on Army installations in the continental United States (CONUS) based on projected climate-change effects. The energy-consumption analysis extended several decades into the future. Drivers of energy-consumption change in this study are limited to direct and indirect consequences of climate changes, but exclude imponderables such as potential changes in installation renewable-energy adoption, mission realignment, etc. 


\section{Historic Installation Energy Requirements}

\subsection{Energy utilization overview}

All Army installations are dependent on energy to satisfy their mission. Abundant and secure supplies of energy in various forms are necessary to allow the Army to train, maintain, feed, and house soldiers, family members, and the civilian workforce. Energy is used to heat, cool, ventilate, and provide lighting in administrative and training facilities, shops, barracks, and housing facilities; to process information and provide communications; to repair and maintain equipment; and power a multitude of other functions. One cannot imagine a modern Army installation operating effectively without ready, reliable, and secure access to the amounts and kinds of energy it requires.

Fortunately, CONUS Army installations have had ready access to energy resources in sufficient quantities to support their mission requirements. Except for rare exceptions, Army installations have enjoyed an almost uninterrupted supply of energy in the form of electricity, natural gas, propane, fuel oil, and other energy sources. Increasingly, renewable energy in the form of electricity generated by wind and photovoltaics, solar thermal energy, and other sources have been added to the Army's energy supply portfolio. Although renewable energy sources currently account for a small fraction of the energy requirements of most installations, this fraction is expected to grow significantly as installations strive to achieve Net Zero Energy status.

Before the 1970s, abundant low-cost energy was taken for granted. Both the private and public sectors gave little thought to the cost or availability of energy because all forms of it were relatively inexpensive, and there was little public consideration that energy resources were finite and exhaustible. Because widespread environmental awareness had not yet emerged, many facilities were heated with higher-emission resources such as coal or fuel oil. Outside of hot locations, many buildings were not air-conditioned. Comfort cooling, especially in older buildings, was often accomplished by opening windows or using electric fans. The concept of indoor air quality was unknown then, and ventilation efficacy was not a significant concern because most building envelopes were so poorly sealed that natural convection and infiltration provided sufficient ventilation. 
Also, computers were largely unheard-of on installations before the 1970 . Communications were almost exclusively accomplished by telephone or interoffice mail. Information processing and management was largely accomplished by hand, reproduced on carbon paper forms or mimeograph machines and distributed by interoffice mail. In other words, information processing and exchange required relatively little in terms of energy.

\subsection{Federal energy policy}

The federal government has been involved with energy production and delivery since at least 1920, when the Federal Power Act created the Federal Power Commission to coordinate federal hydroelectric projects (Federal Power Act 1920). Since that time, a variety of federal statutes and regulations have been promulgated to promote electrification of underserved parts of the country, promote and regulate the development of nuclear power, establish transportation fuel economy standards, and encourage energy conservation in homes, schools, and public buildings.

The Energy Policy Act (EPAct) of 1992 directed the federal government to decrease energy consumption in federal buildings when feasible, and to integrate the use of alternative fuel vehicles in federal and state fleets. Title XXII in the EPAct authorized tax incentives and marketing strategies for renewable energy technologies in an effort to encourage commercial sales and production. Two of the most significant federal energy legislation packages passed in the previous 15 years are the

- Energy Policy Act (Public Law 109- 58) (8 August 2005)

- Energy Independence and Security Act of 2007 (December 2007).

These statutes were implemented through executive actions such as

- Executive Order 13423, Strengthening Federal Environmental, Energy, and Transportation Management (24 January 2007)

- Executive Order 13514, Federal Leadership in Environmental, Energy and Economic Performance (5 October 2009).

Most recently, Executive Order 13693, Planning for Federal Sustainability in the Next Decade (March 25, 2015) raised targets for energy efficiency, reductions in greenhouse gases, and increasing reliance on renewable and clean energy sources. Executive Order 13423, Executive Order 13514, and other Executive Orders and Presidential Memoranda were revoked by EO 
13693. This order imposed more stringent requirements on federal agencies, including the following, as extracted from Section 3, "Sustainability Goals for Agencies":

(a) promote building energy conservation, efficiency, and management by:

(i) reducing agency building energy intensity measured in British thermal units per gross square foot by 2.5 percent annually through the end of fiscal year 2025, relative to the baseline of the agency's building energy use in FY 2015.

(b) ensure that at a minimum, the following percentage of the total amount of building electric energy and thermal energy shall be clean energy, accounted for by renewable electric energy and alternative energy:

(i) not less than 10 percent in fiscal years 2016 and 2017;

(ii) not less than 13 percent in fiscal years 2018 and 2019;

(iii) not less than 16 percent in fiscal years 2020 and 2021;

(iv) not less than 20 percent in fiscal years 2022 and 2023; and

(v) not less than 25 percent by fiscal year 2025 and each year thereafter;

(c) ensure that the percentage of the total amount of building electric energy consumed by the agency that is renewable electric energy is:

(i) not less than 10 percent in fiscal years 2016 and 2017;

(ii) not less than 15 percent in fiscal years 2018 and 2019;

(iii) not less than 20 percent in fiscal years 2020 and 2021;

(iv) not less than 25 percent in fiscal years 2022 and 2023; and

(v) not less than 30 percent by fiscal year 2025 and each year thereafter.

In carrying out their mandate to comply with federal laws and executive orders, the Department of Defense (DoD) and military departments have established their own energy goals and objectives. DoD acknowledged the effects of climate change in the 2010 Quadrennial Defense Review (QDR). As shown in Figure 1, DoD recognizes the need to adjust to the impacts of climate change on its facilities and military capabilities. 
Figure 1. Slide from DASA E\&S presentation

"Army Energy and Sustainability Program."

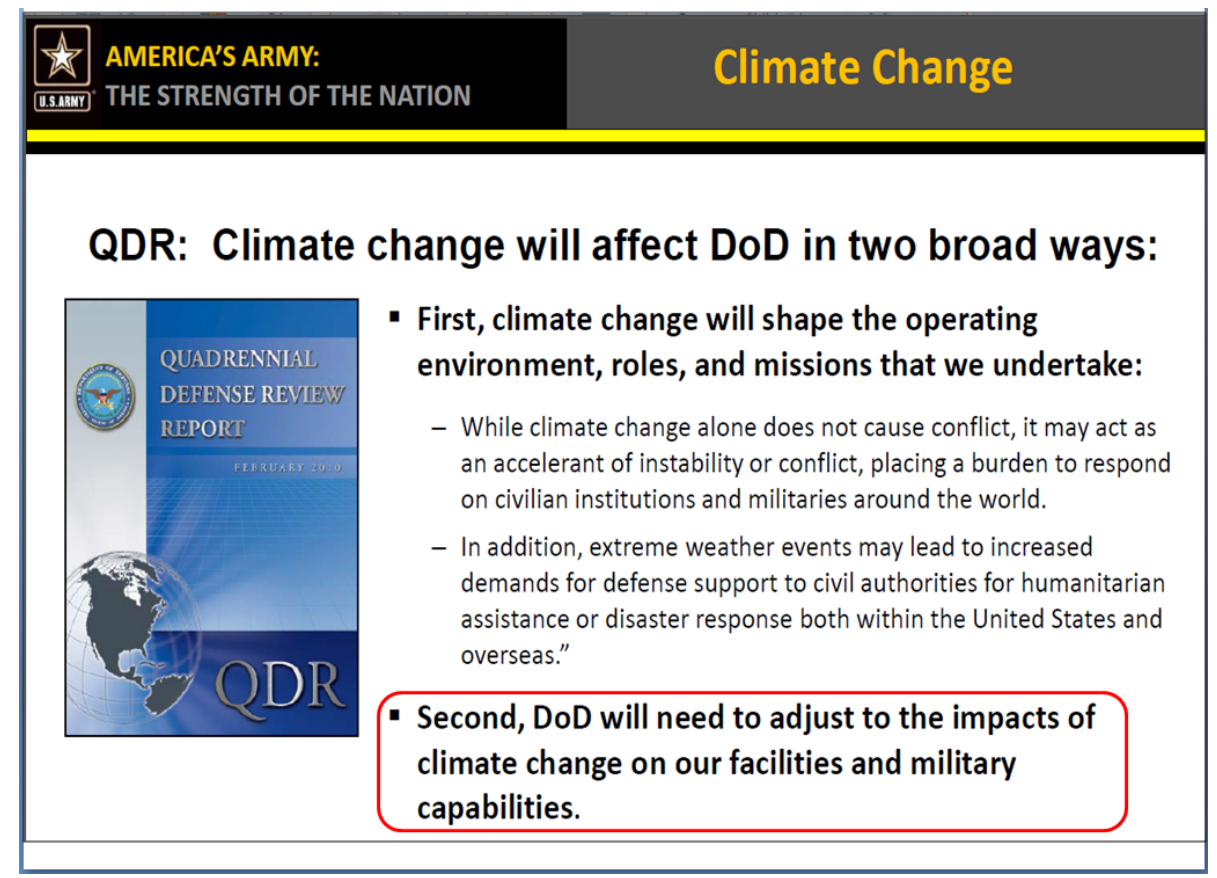

The Army has aggressively pursued energy and sustainability compliance with policy initiatives such as those shown in Figure 2.

Figure 2. Roadmap of Army efforts to comply with Federal energy and sustainability policies.

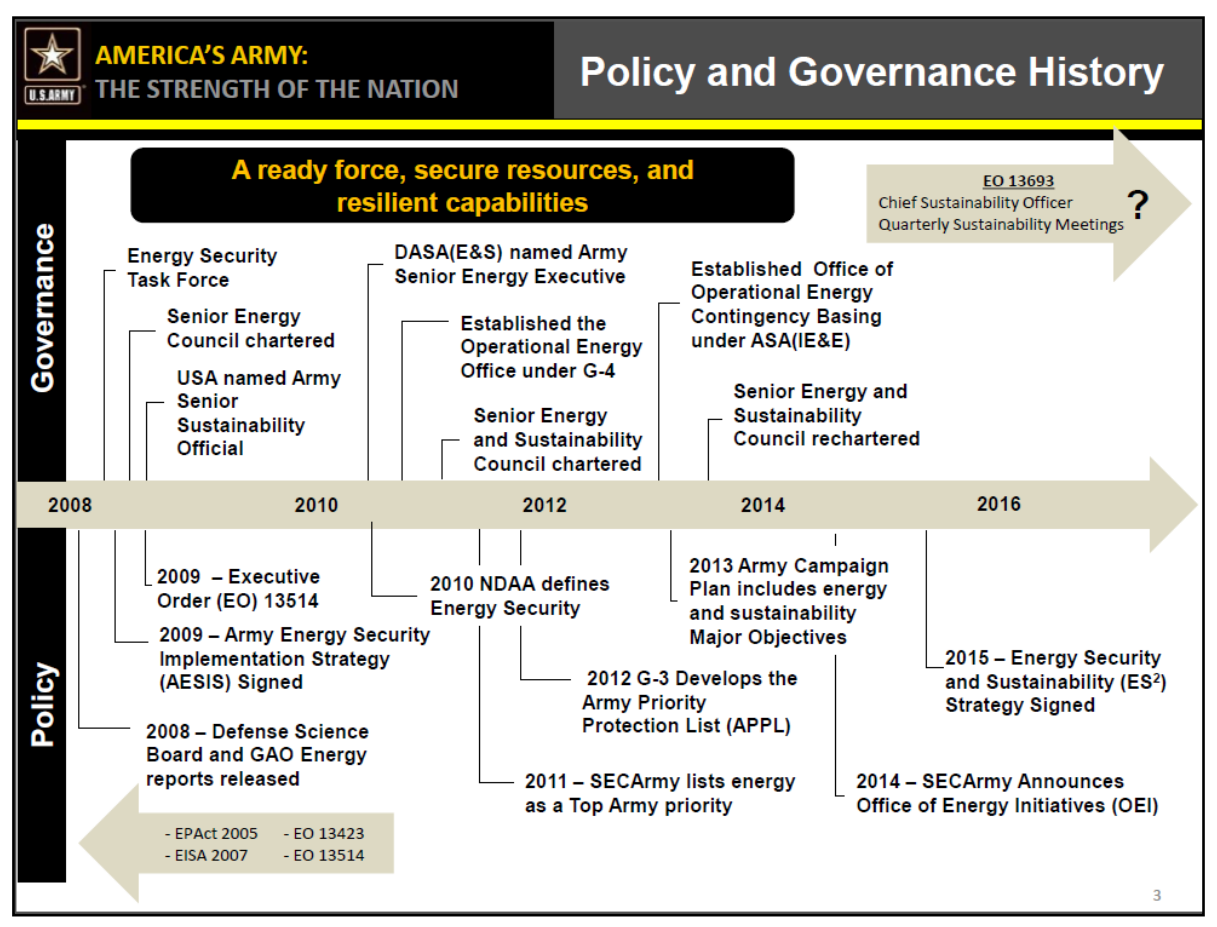




\section{Army Climate-Change Challenges}

\subsection{Climate change trends and model projections}

Numerous climate studies and assessments have noted trends toward more frequent and/or more intense weather events such as heat waves, heavy downpours, floods, and droughts. Rising sea levels, higher ocean acidity, and melting glaciers and arctic sea ice are other indications of climatic change. Scientists predict these changes to continue and possibly increase in frequency or duration over the next 100 years.

Per the High-Level Climate Change Vulnerability Assessment, mean temperatures across all periods and emissions scenarios are expected to increase over the 1971-2000 reference period across the nation, with the greatest increase in the contiguous 48 states projected to occur in the upper Great Plains and Midwest. Increases along coastal areas are projected to be less because of moderating ocean effects. Seasonal increases are generally projected to be greater in summer than in other seasons.

Coupled Model Intercomparison Project 3rd phase (CMIP3) simulations project median temperature increases ranging from $3{ }^{\circ} \mathrm{F}$ in the $2021-2050$ timeframe to $4.5^{\circ} \mathrm{F}$ in the 2070-2099 time period. Individual model low and high values were $1.6^{\circ} \mathrm{F}$ and $6.3{ }^{\circ} \mathrm{F}$, respectively. Temperature increases for interior regions of Alaska are projected to be higher than any area in the contiguous 48 states.

The number of consecutive days with temperatures $>95{ }^{\circ} \mathrm{F}$ is expected to increase across the country, particularly in the Southwest U.S. and the southern Great Plains. The number of days $<10^{\circ} \mathrm{F}$ is expected to decrease particularly in higher elevations of the mountainous west and along the northern tier of states.

The national climate outlook also indicates changes in precipitation patterns across the nation with greatest increases in the upper Midwest and northern states and the greatest decrease in the Southwest and southern Great Plains. The North American Regional Climate Change Assessment Program (NARCCAP) simulations for 2041-2070 indicate decreased precipitation in the spring and summer seasons in the southwest U.S. and winter season increases in the north-central and northeast U.S. 
Most areas of the U.S. are projected to experience increases in extreme precipitation events ( $>25 \mathrm{~mm}$ per 24 hours), with the greatest percentage change ( $>60 \%$ ) in the number of days with precipitation exceeding 1 in. during 2041-2070 in areas west of the Rocky Mountains. Change in the consecutive days of low precipitation ( $<3 \mathrm{~mm}$, an indicator of drought) is expected to be greatest in the southwest U.S., with increases in southern California and Arizona of up to 30 days.

These NCA outlooks are based on a set of climate projections of outcomes that could occur under a set of possible scenarios, but are not predictions of specific climatic outcomes. The future trends in emissions and global economic growth rates that can influence these trends are not reliably predictable. These projections represent a range of expected future climate changes based on observed greenhouse gas trends and trends in energy use. With respect to the available scientific data on climate trends, DoD has established policies to actively control climate change drivers and to plan for future climate change impacts.

Per Executive Order 13514, Federal Leadership in Environmental, Energy, and Economic Performance (October 5, 2009, revoked by Executive Order 13693, March 25, 2015), all federal departments and agencies are required to evaluate climate change risks and vulnerabilities to manage short- and long-term effects of climate change on the agency's mission and operations; and to include an adaptation planning document as an appendix to its annual Strategic Sustainability Performance Plan (SSPP). Executive Order 13653, Preparing the United States for the Impacts of Climate Change (November 6, 2013) went further, stating that

each agency shall develop or continue to develop, implement, and update comprehensive plans that integrate consideration of climate change into agency operations and overall mission objectives and submit those plans to CEQ (Council for Environmental Quality) and OMB (Office of Management and Budget) for review.

\subsection{DoD and Army responses to climate change}

The DoD recognizes the need for a strategic approach to the challenges posed by global climate change, including potential impacts to missions, built infrastructure, and natural resources on DoD installations.

Swearingen et al. (2016) provide a detailed synopsis of federal climate 
change directives and their implementation through the military departments and services.

Executive Orders, the CEQ, and the Climate Change Adaptation Work Force have impelled DoD elements to enact climate change policy guidance. The 2010 Quadrennial Defense Review (QDR) identifies climate change as a serious issue that is to be directly considered in long-term Army planning. The QDR, which is the principal instrument through which the National Defense Strategy is implemented as new policies and initiatives, states that DoD "must complete a comprehensive assessment of all installations to assess the potential impacts of climate change on its missions and adapt as required."

In response to the QDR mandate, the DoD Strategic Sustainability Performance Plan (2010) identified the need to integrate climate change considerations into existing processes using robust decision-making approaches based on the best available science. The Army DoD Climate Change Adaptation Roadmap (2012) recognized that climate change interacts with stressors that the Army already considers and manages. In the $2013 \mathrm{Re}-$ port to Congress on Sustainable Ranges, the Army reported progress toward achieving DoD policy goals by integrating climate change issues into existing processes instead of considering it as an isolated issue. DoD intends to fully integrate climate change considerations into its more general policies, planning, practices, and programs, and directs its Senior Sustainability Council (SSC) to establish policies and guidance for conducting consistent climate change vulnerability assessments across DoD components. Most recently, the President's Climate Action Plan (June 2013) reemphasized the need to develop tools for more effective climate-relevant decision making.

The Office of the Assistant Secretary of the Army for Installations, Energy, and Environment OASA (IE\&E) has the lead responsibility for integrating climate change topics into Army planning processes. In FY12, OASA (IE\&E) tasked ERDC to develop an adaptation-planning framework that is consistent with CEQ priorities and the DoD Climate Change Adaptation Roadmap to integrate climate change planning into ongoing Army installation planning processes. That effort has considered five major Army installation planning instruments, i.e., the Installation Strategic Plan, Installation Master Plan, Installation Range Complex Master Plan, Installation Integrated Natural Resource Management Plan, and Installation Critical 
Infrastructure Risk Management Plan. The effort did not address Army enterprise-level planning processes such as BRAC, stationing decisions, or acquisition. The Army currently lacks approaches and tools to incorporate climate change projections into enterprise-wide decision processes. The objective of the present work is to address that Army planning gap.

\subsection{General implications for Army planning and operations}

Army long-term, enterprise-scale stationing decisions will be significantly influenced by the inherent impacts of climate change and emerging weather events on military training and testing missions as well as the operation and maintenance of built and natural infrastructure. Future weather emerging from climate change will be altered on short-, mid-, and long-term time scales, and also in terms of frequency, variability, and duration of extreme events. Therefore, there is a need to support the planning decision process and associated assessments of enterprise systems and installation functions with regard to their vulnerabilities to these future impacts.

Without an ability to assess and incorporate changing future conditions into Army planning scenarios, mission success as well as the long-term sustainability of the Army enterprise could be compromised. Historically, decision processes supporting enterprise and installation planning have assumed that current environmental conditions will be static and persist as such into the future. Consequently, installation metrics used in longterm enterprise planning (e.g., BRAC, stationing, and land set-asides) are fixed values across the planning horizon. The various metrics used were created to collectively represent the capabilities, value, and costs incurred by installations in meeting mission requirements. At this time, the Army does not have an objective, repeatable, time-relevant, and cost-appropriate approach to assess how these metrics might change as a consequence of climate-related dynamics.

Changing climate will begin to affect (and in some cases is already affecting) urban development, water resources, and habitat for threatened and endangered species-all factors that are relevant to a military installation's long-term viability for mission success and conceptually related to current decision metrics. Army-relevant models for various natural and built systems exist, but do not account for cause/effect relationships associated with climate change (from short term to long term). 


\subsection{Specific implications for the Army}

Specific systems that are most pertinent and essential for assessment include: infrastructure and energy, water availability, climate-dependent noise propagation, urban growth and encroachment, threatened and endangered species, and climate-aggravated training impacts. These are outlined as follows:

\subsubsection{Infrastructure and energy}

Increased temperatures and increased residential, commercial, industrial, and agriculture loads increase demands on energy sources and energy distribution networks, potentially resulting in local or regional brownouts. Temperature changes also impact facility operating and maintenance costs.

In FY16 the research team investigated how climate change might impact renewable energy potential and installation electrical energy security. With federal statutes, executive orders, and DoD/Army goals and policies steadily pushing towards greater energy efficiency, broader use of renewable and clean energy sources, it would seem obvious that climate change effects on renewable energy potential should not be overlooked. However, our investigation of this aspect of energy implications was not able to draw any clear, supportable conclusions due to the many uncertainties that the renewable energy market encompasses. For example, climate scientists are uncertain how climate change will affect cloud cover and wind. Warmer temperatures will modestly reduce efficiency of photovoltaic systems. Fortunately, it appears that the falling costs of renewable energy systems will more than offset any loss of efficiency of renewable energy systems. This is discussed in Appendix A.

\subsubsection{Water availability}

The availability, quality, and cost of water is crucial to sustaining the military mission. Demands on water for regional agriculture, cities, energy sustainability, and habitat security will change with changing climate, urban patterns, and technologies.

\subsubsection{Threatened and endangered species}

The probability of future species listings may impact the availability of Army training and testing lands and their associated management costs. 


\subsubsection{Climate-aggravated training impacts}

A critical and limiting Army asset is its training and testing areas, especially large-maneuver landscapes. Climate may significantly alter the resiliency of natural vegetation in maneuver areas, having secondary effects on the soil resource, which if degraded will negatively impact the land's training capacity and maintenance costs.

\subsubsection{Climate-dependent noise propagation}

The propagation of noise from military training and testing activities restricts access to training and testing areas. Weather conditions may alter the propagation of noise beyond installation boundaries. Changing climates potentially impact the number of days ranges can operate without restrictions.

\subsubsection{Urban growth and encroachment}

Urban growth will continue to erode military mission opportunities in several ways, including noise complaints, destruction of habitats suitable for listed species, changes in water demands, and changes in energy demands.

The development of science-based, climate-sensitive enterprise decisionmetrics and associated data and models that enable regional and national scale assessments is critical to meeting Army objectives. The ability to perform informed risk analysis, forecast future scenarios of competing enterprise investment, and assess future facility values and costs will allow the Army to save both time and money over the near and far term.

\subsection{Regional climate change implications}

Observed and projected climate-change impacts will vary across the regions of the United States. As a result of these regional variations, the Army needs to consider these regional impacts in its long-range planning activities (summarized in Table 1). 
Table 1. U.S. regional variations in climate-change impacts.

\begin{tabular}{|c|c|}
\hline Region & Climate Impacts \\
\hline Northeast & $\begin{array}{l}\text { Communities are affected by heat waves, more extreme } \\
\text { precipitation events, and coastal flooding due to sea level rise } \\
\text { and storm surge. }\end{array}$ \\
\hline Southeast & $\begin{array}{l}\text { Decreased water availability, exacerbated by population growth } \\
\text { and land-use change, causes increased competition for water. } \\
\text { There are increased risks associated with extreme events such } \\
\text { as hurricanes. }\end{array}$ \\
\hline Midwest & $\begin{array}{l}\text { Longer growing seasons and rising carbon dioxide levels } \\
\text { increase yields of some crops, although these benefits, have } \\
\text { already been offset in some instances by occurrence of } \\
\text { extreme events such as heat waves, droughts, and floods. }\end{array}$ \\
\hline Great Plains & $\begin{array}{l}\text { Rising temperatures lead to increased demand for water and } \\
\text { energy and impacts on agricultural practices. }\end{array}$ \\
\hline Southwest & $\begin{array}{l}\text { Drought and increased warming foster wildfires and increased } \\
\text { competition for scarce water resources for people and } \\
\text { ecosystems. }\end{array}$ \\
\hline Northwest & $\begin{array}{l}\text { Changes in the timing of stream flows related to earlier } \\
\text { snowmelt reduce the supply of water in summer, causing far- } \\
\text { reaching ecological and socioeconomic consequences. }\end{array}$ \\
\hline Alaska & $\begin{array}{l}\text { Rapidly receding summer sea ice, shrinking glaciers, and } \\
\text { thawing permafrost cause damage to infrastructure and major } \\
\text { changes to ecosystems. Impacts to Alaska Native communities } \\
\text { increase. }\end{array}$ \\
\hline Hawaii & $\begin{array}{l}\text { Increasingly constrained freshwater supplies, coupled with } \\
\text { increased temperatures, stress both people and ecosystems } \\
\text { and decrease food and water security. }\end{array}$ \\
\hline Coasts & $\begin{array}{l}\text { Coastal lifelines, such as water supply infrastructure and } \\
\text { evacuation routes, are increasingly vulnerable to higher sea } \\
\text { level and storm surges, inland flooding, and other climate- } \\
\text { related changes. }\end{array}$ \\
\hline
\end{tabular}




\section{Analytical Method}

\subsection{Goal of FY15 study}

The purpose of the FY15 investigation was to develop a methodology to predict the impact on installation energy consumption based on projected climate changes. Presumably, climate change would result in generally warmer temperatures at many locations, but it would be hasty to assume that temperatures generally would rise at all locations. Therefore, the methodology would use the best available historical information, combined with climate projections, to predict and compare the relative impact of climate change on any Army installations that might be analyzed in future stationing decisions.

\subsection{Assumptions}

For purposes of this study, a number of significant simplifying assumptions were employed in our analysis:

a. Consideration was limited to historic dry bulb temperatures (DBT) and projections of DBT data as influenced by climate change. Historic or projected dew point temperature (DPT) data were not considered. Dew point temperatures are a measure of absolute humidity levels, and when used in conjunction with dry bulb temperatures are used to determine the relative humidity levels of air. Moisture content of air has a major impact on cooling energy requirements so that buildings in humid areas (such as the southeastern United States) require significantly more cooling energy to maintain comfort conditions than comparable buildings in semiarid regions (such as the southwestern United States) at similar ambient dry bulb temperatures.

b. The researchers did not account for the fact that historic monthly average temperature data significantly simplified the hour-by-hour recorded temperatures over a month down to a single monthly average temperature. Obviously, real temperatures follow a diurnal cycle and can fluctuate widely over the course of any given day and throughout the month. A day or month with widely fluctuating temperatures (i.e., a large standard deviation) can be expected to have greatly differing heating and cooling requirements than a day or month with a similar 
daily or monthly average temperature but less overall fluctuation (i.e., a smaller standard deviation) about the mean temperature.

c. The researchers also did not account for other climate factors such as historic and projected solar insolation, cloud cover, precipitation levels, or wind patterns. Although these historic data are readily available, projections of these data into the future are highly speculative, so analyses dependent upon such projections would incorporate the uncertainties associated with those factors.

d. Although we referenced historic installation conditioned building space in our analyses to develop installation-specific EUI characteristic curves, the final product-a time series of projected installation EUIsis reported independently of installation building space numbers. This approach will allow Army planners to apply the projected EUI numbers to their own projections of installation square footage to estimate future energy requirements.

e. The analysis made no attempt to consider or account for any increased penetration of installation air conditioning requirements. It is almost certain that air conditioning penetration will increase, especially in regions that currently have relatively low cooling loads but are projected to experience significant warming in future years. Nevertheless, penetration of air conditioning is often driven not only by climate conditions but also by policies and regulations that can be difficult to predict and track.

f. Most Army installations are exhibiting trends of reduced EUIs as they respond to various statutes, Executive Orders, departmental policies, and other drivers to improve their overall energy efficiency and meet energy reduction targets. Nevertheless, even though it is apparent that many Army installations have had historic EUI reductions over time, it is difficult to project those trends into the distant future. Therefore, we assumed no significant future change in the energy efficiencies of installation building inventories arising from improved building technologies, replacement of old, inefficient buildings with new, efficient ones, or operational efficiencies that are independent of local climate characteristics. 
g. The analysis assumed no significant change in the mix of energy sources used to heat and cool the installation. For example, we did not consider the fact that an installation currently using both propane (a relatively expensive energy source) and natural gas (a comparatively inexpensive energy source) for heating might migrate over time towards more use of natural gas and less dependence on propane. Unless an installation showed a clear historic trend of moving toward greater reliance on natural gas and less use of propane, for example, it was assumed that current usage patterns would persist.

h. We did not account for the possibility that an installation's energy source profile might shift in other ways over time. For example, an installation might construct a microgrid and install cogeneration capacity to offset a portion of its current purchased utility requirements. Such a move would often have the effect of increasing natural gas usage while reducing consumption of purchased electrical energy, but attempts to predict the actual impacts would face numerous uncertainties.

i. Although renewable energy capacity at Army installations will likely increase in the future, we could not determine a straightforward way to project future penetration of these technologies. Therefore, we did not consider the expanded use of renewable energy sources such as onsite photovoltaics, wind energy, solar thermal, geothermal, or biomass energy that would reduce an installation's current purchased utility requirements.

j. We did not consider any changes in mission activities that would affect installation energy requirements independently of local climate conditions. For example, we did not try to account for the possibility that a given installation might in the future gain or lose a large energy consumer such as an industrial operation, a data center, a simulator mission, etc.

$\mathrm{k}$. The analysis avoided projections of future installation energy costs because there are too many unknowns in the unit cost of energy.

Note that any one of these assumptions could have a significant impact on the relative projections of energy consumption between two or more installations being considered. Nevertheless, these items were established as 
constants in order to identify potential future impacts due solely to climate change.

\subsection{General approach}

At the outset, we considered the most likely impact of climate change on installation energy. Of the various energy consuming processes at an installation (such as heating, cooling, ventilating, lighting, food processing, data processing, communications, maintenance/repair, etc.), we assumed that climate changes (typically manifested as outdoor ambient dry bulb temperature changes) would primarily impact building heating, ventilation and cooling (HVAC) processes. This is not to suggest that ambient temperature changes would not affect other processes or processes, but we assumed that climate change effects on other processes would be much less significant and much more difficult to measure or predict.

Climate change is expected to affect other climate parameters besides outdoor ambient dry bulb temperatures. For example, climate change is expected to impact precipitation levels, dew point temperatures (DPT, a measure of absolute humidity levels), cloud cover, and wind characteristics. Based on discussions with climate experts, we decided not to consider climate-change impacts on dew point temperatures, cloud cover, and wind because the various general circulation models (GCMs) currently in use diverge widely in terms of their projections. For purposes of this work, it was assumed that future relative humidity levels would be similar to current patterns.

With a focus on climate change impacts on HVAC processes, we considered a way to predict how climatic temperature changes would affect an installation's energy usage. The method needed to provide reasonable results within the limits of accuracy of the available data. We also were looking for a method that would be understandable and appropriately simple so that the analysis process could be performed in a reasonable time frame and without requiring an undue amount of effort to access the required input data or an inordinate amount of specialized expertise to perform the analysis or to interpret the results.

We considered an approach taken by Ahl, DeBaillie, and Schuetter (2013) to project the impacts of climate change on the John C. Stennis Space Center (SSC). Those researchers plotted the campus hourly electric demand 
for both occupied and unoccupied periods as a function of outdoor ambient dry bulb temperature, as shown in Figure 3. They found that SSC electrical usage consisted of a climate-independent base load and load that had some degree of climate dependency. Of this climate-dependent load, there appeared to be an ambient temperature dividing regions of minimal climate dependence and strong climate dependence. The team divided the campus buildings into categories and developed energy models for those categories of buildings. They then modeled how energy consumption in these categories of buildings would be impacted by climate change using projected temperature data from two different climate models.

Figure 3. Campus hourly electric demand versus outdoor dry bulb temperature for both occupied and unoccupied times.

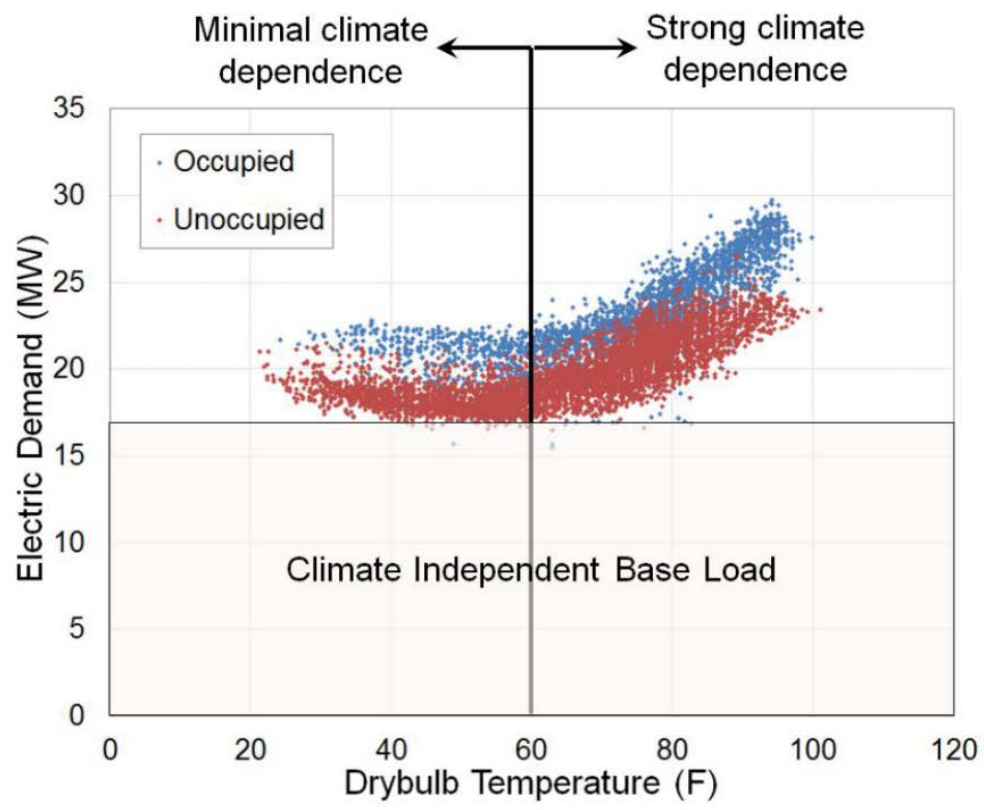

The SSC study informed our approach to modeling of climate-change impacts on Army installations. Similar to the SSC study, we decided to model Army installation utility usage as a function of outdoor ambient dry bulb temperature. However, our approach differed from Ahl, DeBaillie, and Schuetter (2013) in a number of significant ways:

- Due to the scale and complexity of most Army installations in comparison to SSC, we elected not to attempt to develop energy models of buildings or categories of buildings which would have been extremely difficult and time consuming. Considering that our approach might someday be used to analyze a large number of installations in a short period of time, we decided that a rapid but less-rigorous approach 
would be more useful than a highly rigorous approach requiring much more time to complete.

- Our approach had to work with much-less-granular data than the SSC study team had available. The electrical portion of the SSC study had access to much richer data on energy consumption and temperature. Presumably, SSC had access to hourly (or more frequent) electrical demand data and corresponding outdoor dry bulb temperature data. For our purposes, we only had access to reported monthly utility data. Corresponding monthly average temperature data was obtained from local weather stations.

- Unlike the SSC team, we had no way of differentiating between occupied and unoccupied periods.

- Our study considered the full range of energy resources used by installations, whereas the SSC study dealt only with electricity and natural gas.

In order to minimize the complexity of our method and provide output that would be simple to understand and strictly based on climate change effects, it was decided to provide output in the form of a time series of EUI projections for installations in five-year increments. Table 2 shows the format of the outputs of our analysis for a representative "Installation X."

Table 2. Presentation format of results of this analysis for Installation X.

\begin{tabular}{|l|l|l|l|l|l|l|l|}
\hline & 2020 & 2025 & 2030 & 2035 & - & - & $20 x x$ \\
\hline EUI Upper Bound & & & & & & & \\
\hline EUI Mean & & & & & & & \\
\hline EUI Lower Bound & & & & & & & \\
\hline
\end{tabular}

The simplified form of the results shown in Table 2 eliminates conjecture concerning the future state of installations, including the physical plant (square footage) of each installation and the relative energy performance of an installation's real property inventory. This approach eliminates speculation that over time, inefficient buildings will presumably be replaced by more-efficient buildings and that new technologies applied in existing and new facilities will presumably improve installation energy efficiency, given the same climate conditions, the same occupancy, and the same mission. By making these significant simplifying assumptions, we minimized the number of independent variables so that the dependent variable (installation energy consumption) would be influenced by a single independent variable (local outdoor ambient dry bulb temperature). 


\subsection{Detailed approach}

Our approach relied upon historic installation energy usage data and historic installation building square footage data, both of which are archived in the Army Energy and Water Reporting System (AEWRS) database. Appendix B lists 144 Army installations in this database and various metadata about each, including their suitability for the present analysis.

Energy usage data are reported on a monthly basis and square footage data are reported on a quarterly basis. We combined monthly installation energy consumption data with installation building square footage data to establish a monthly installation EUI in units of million BTUs per thousand square feet (MMBTU/kSF) of building area.

We also relied upon the National Oceanic and Atmospheric Administration's (NOAA 2016) Global Surface Summary of the Day (GSOD) historic weather database. This online database contains data reported by over 9,000 weather stations worldwide, many of them reporting back to 1929 . For most CONUS Army installations, there are reporting stations within reasonable proximity to the installation, typically at military or commercial airfields. Based on GSOD data, we calculated monthly mean ambient temperatures (monthly average temperatures), then plotted installation monthly EUIs against corresponding monthly average temperatures, resulting in scatter plots for each installation similar to that shown in Figure 4.

Figure 4. Notional plot of monthly EUI vs monthly average temperature.

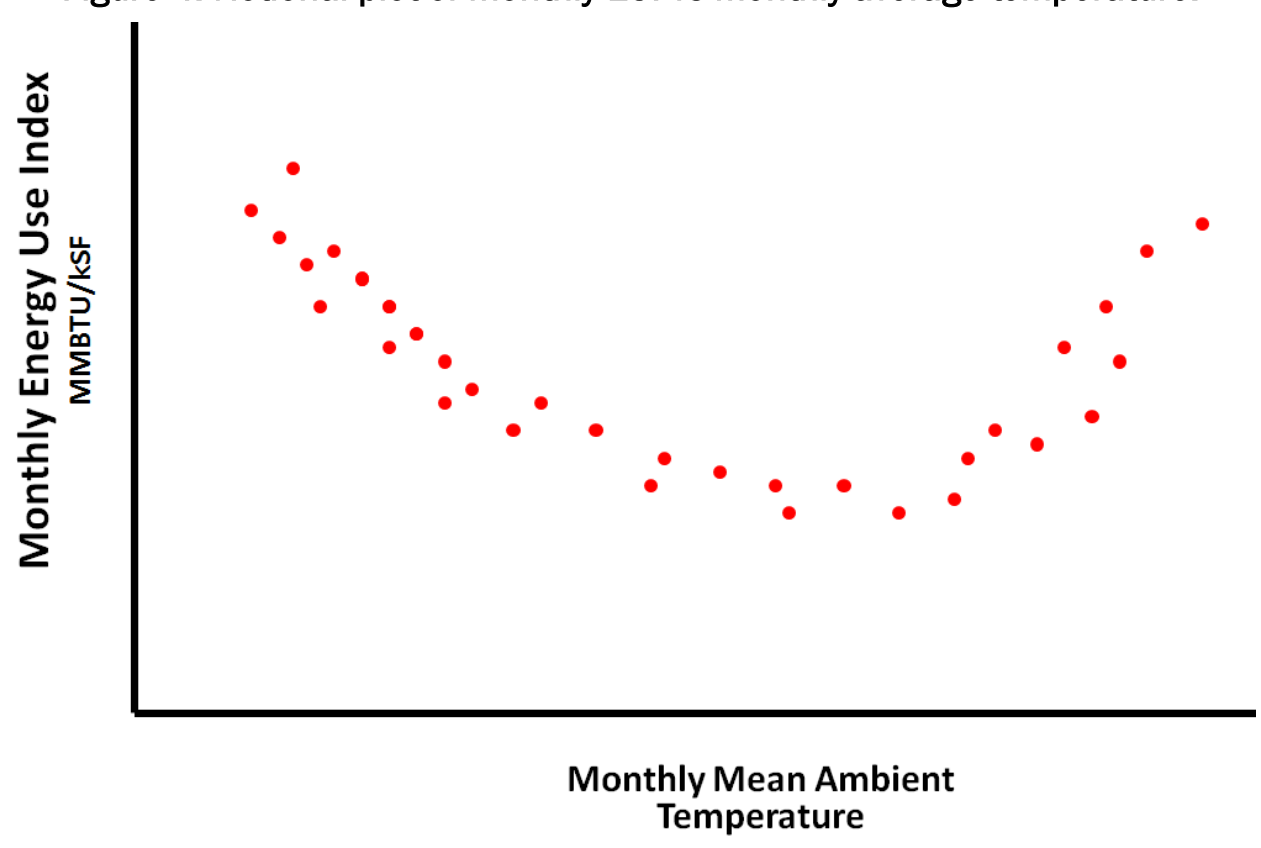


In Figure 4 one can see a general trend of high EUIs at low monthly mean ambient temperatures (or monthly average temperature [MAT]), decreasing to a minimum EUI at some intermediate monthly average temperature and then increasing at higher monthly average temperatures. This is fairly typical for many installations and somewhat intuitive. At lower monthly average temperatures, one would expect most installations to experience high EUIs due to the need to satisfy building heating loads. At warmer monthly average temperatures, one would also expect most installations to experience higher EUIs due to the need to satisfy higher building cooling loads.

For each installation, we fitted a least squares curve in the form of EUI $=\mathrm{f}$ (monthly average temperature) through the scatter plot data points as shown in Figure 5. The graphs for no two installations are exactly similar so that a curve fitted to the data points on a monthly EUI vs monthly average temperature graph for a particular installation will be "characteristic" of that installation. Characteristic curves vary from one installation to another based on myriad causes, including each installation's mix of facility types, facility ages and conditions, mission requirements and other factors.

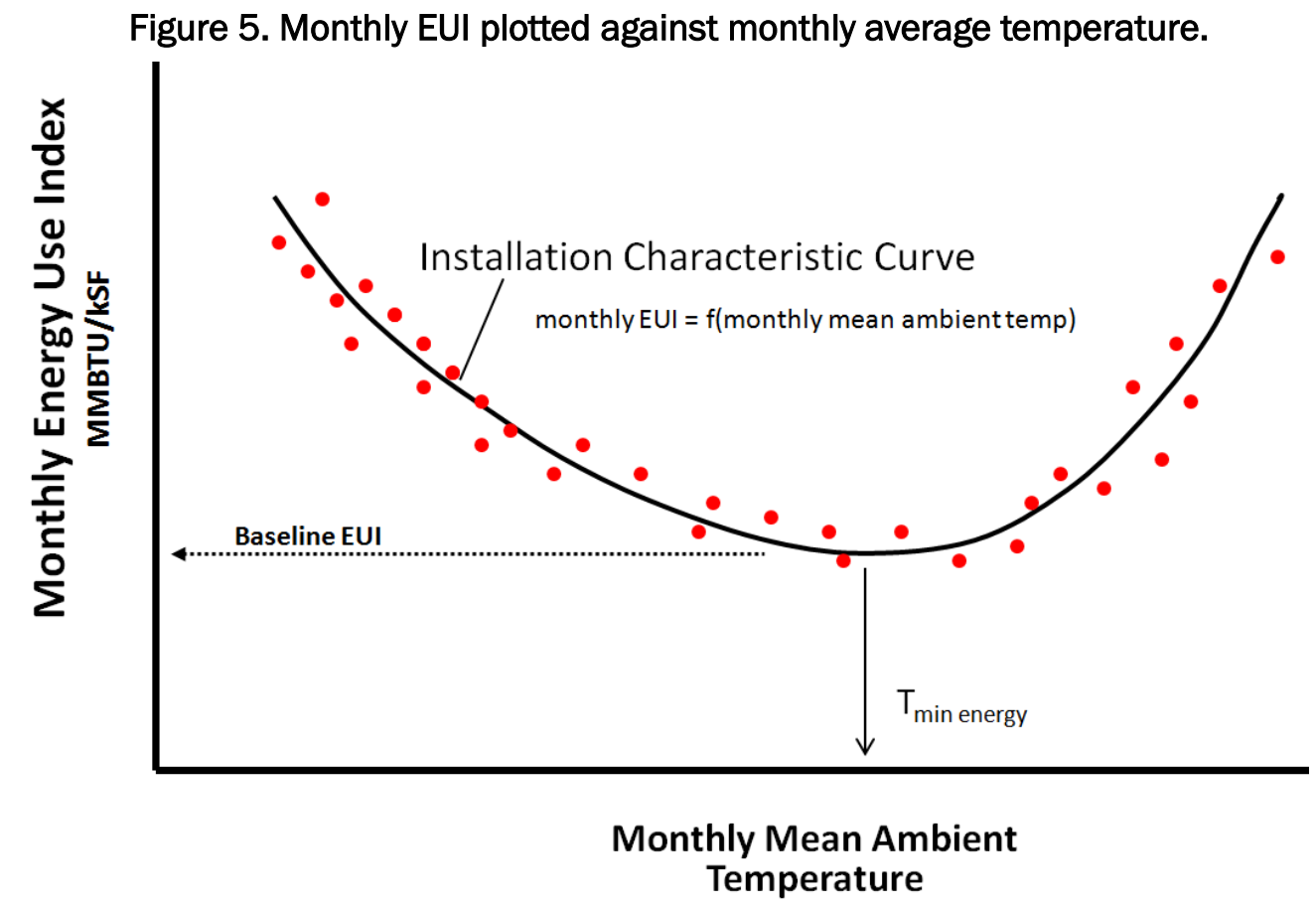

Figure 5 also shows that most installations exhibit a minimum monthly EUI (baseline EUI) at a particular monthly average temperature ( $\mathrm{T}_{\text {min }}$ en-

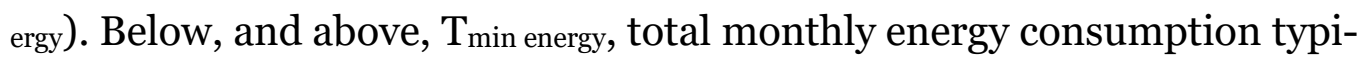


cally increases significantly. Presumably total monthly energy consumption increases at monthly average temperatures below $\mathrm{T}_{\text {min energy for build- }}$ ing heating purposes and increases for months with mean ambient temperatures above $T_{\text {min energy }}$ due to building cooling needs. It was further assumed that total monthly energy consumption below the baseline EUI is characteristic of the installation's facility inventory, mission and other factors and is at least somewhat independent of the monthly average temperature. We attribute total monthly energy consumption above the baseline EUI as being driven mainly by monthly average temperature and, therefore, subject to projected climate change affects.

Initially, we disaggregated installation total monthly energy consumption into the monthly consumption of electrical energy, natural gas energy, propane energy, etc., then plotted characteristic EUI curves for each energy source. As one might expect, it was found that natural gas (NAG), propane (PPG), fuel oil (FSD) and other energy sources primarily used for heating had higher EUIs at lower monthly average temperatures. Conversely, we found that electricity (ELC) tended to have highest EUIs at warmer monthly average temperatures as might be expected because electricity is currently the most widely used cooling energy source at most installations. Individual EUIs for the various energy sources at a "typical" installation are shown in Figure 6.

Figure 6. Monthly EUls vs monthly average temperature for natural gas, propane and electricity at a "typical" installation.

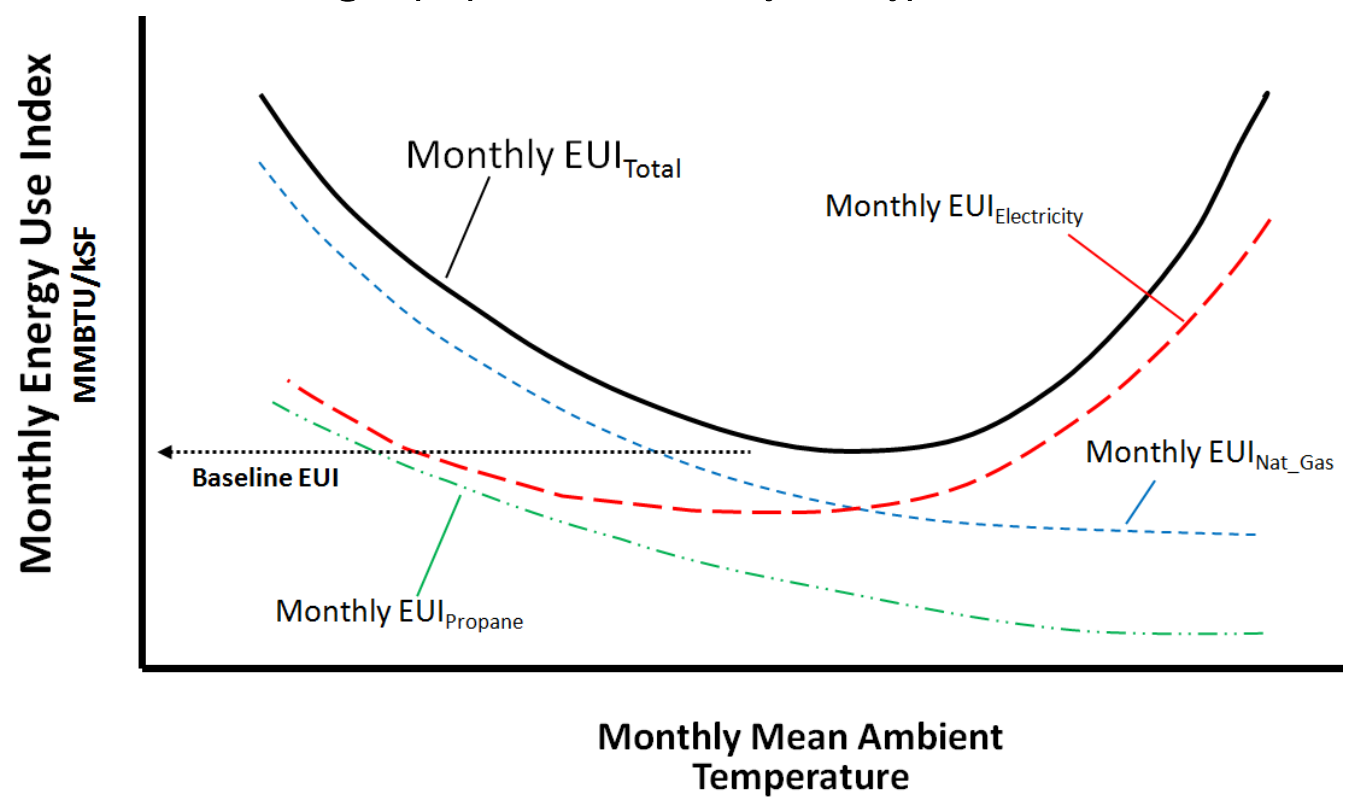


The resulting curve fits would be expressed as follows:

$$
\begin{aligned}
& E U l_{\text {electricity }}=f_{1} \text { (monthly average temperature) } \\
& E U I_{\text {natural gas }}=f_{2} \text { (monthly average temperature) } \\
& E U I_{\text {propane }}=f_{3} \text { (monthly average temperature) }
\end{aligned}
$$

In a possible climate-change scenario with a warming climate, projected monthly average temperatures would exhibit a general shift toward the right. As shown in Figure 7, vertical lines corresponding to these warmer monthly average temperatures can be drawn upward to intersect the characteristic curves for electricity, natural gas and propane. From these points of intersection on the characteristic curves shown in Figure 7, horizontal lines can be drawn to the left to intersect the Projected Monthly Energy Use Index axis. Based on the characteristic curves shown in Figure 7, a warming climate would tend to result in reduced monthly EUIs for natural gas and propane. For electricity, the characteristic curve shown in Figure 7 would suggest that the monthly EUI for electricity would be reduced during cooler months but would increase during warmer months.

Figure 7. Projected monthly EUI (by resource type) vs projected monthly mean ambient temperatures for a notional installation.

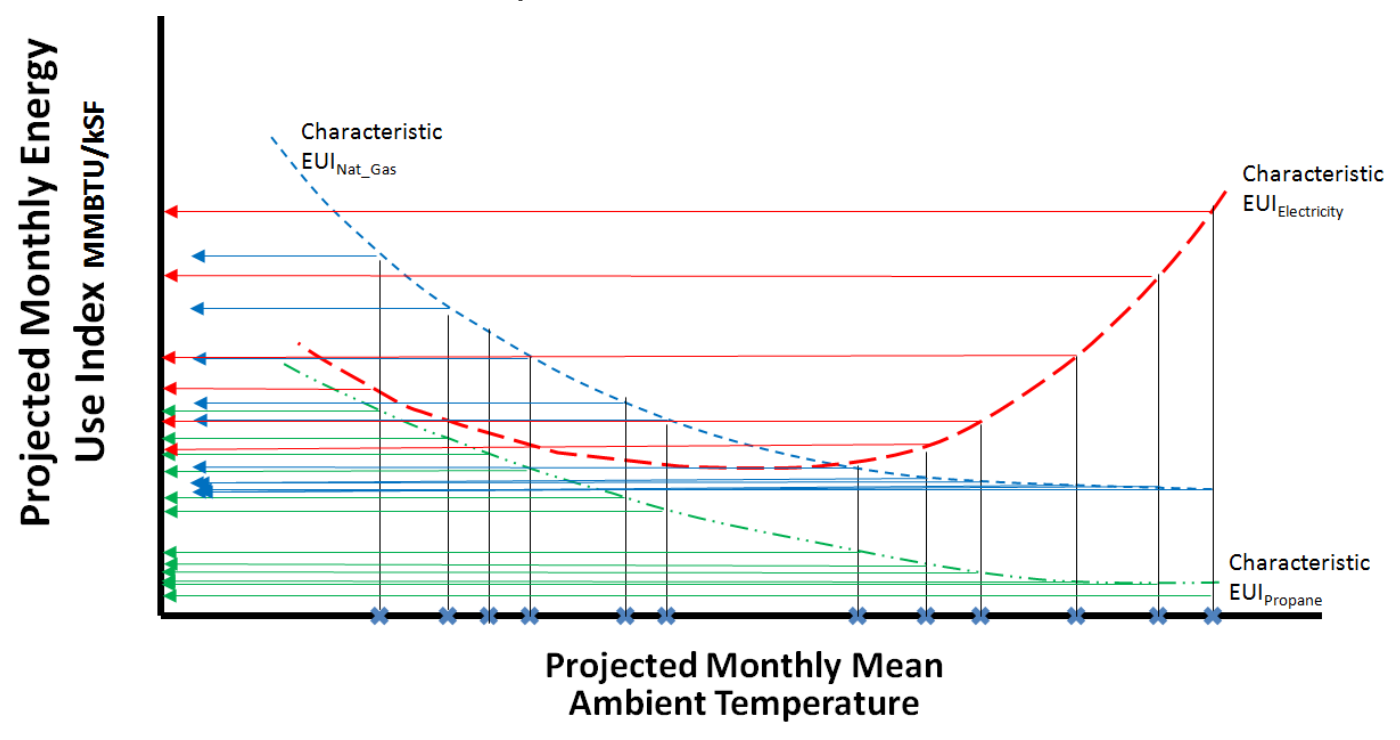

An installation's projected annual installation energy consumption (MMBTU/year) can be obtained by multiplying the Projected Monthly Energy Use Index for each month of a future year of interest by the most current building square footage data shown in the AEWRS database or by a 
projected future building square footage number, then summing the projected monthly energy usages to obtain the installation's projected annual energy consumption. This projected annual energy consumption can then be compared to the installation's total energy consumption for the current year to determine the change in energy consumption resulting from projected climate change effects.

Historic Annual Energy Consumption $=\sum_{i=1}^{n} \quad \sum_{j=1}^{12} M M B T U i j$

where

$$
\begin{aligned}
i= & \text { installation energy sources } \\
j= & \text { months of the year } \\
\text { EUI }= & \sum_{\mathrm{i}=1}^{\mathrm{n}} \quad \sum_{\mathrm{j}=1}^{12} \text { MMBTUij Historic Annual Energy Consumption / } \\
& \text { Historic Area }
\end{aligned}
$$

and

Projected Annual Energy Consumption $=$ Projected Area $x$ EUI Areax $\sum_{\mathrm{i}=1}^{\mathrm{n}} \quad \sum_{\mathrm{j}=1}^{12}$ EUIij

where

Projected Area $=$ Future installation building area $(\mathrm{kSF})$

Future energy costs were not projected because of the possible volatility and unpredictability of unit energy costs. Rather, the data were output as a time series (in five-year increments) of annual EUIs (MMBTU/kSF/year) for the sum of all utility types.

\subsection{Applicability}

For purposes of this project, analysis was applied to five installations: Fort Bliss, Fort Bragg, Fort Carson, Fort Riley, and Fort Sill. However, the process and software tools developed in this work should be applicable to all Army installations for which the required input data are available. 


\section{Data Sources}

\subsection{Data requirements}

In order to perform this analysis, the following data are required for any and all CONUS installations that might be subject to a stationing analysis:

- Historic installation energy data (by utility type)

- Historic installation facility square footage data

- Historic installation mean monthly temperature data

- Projected installation mean monthly temperature data.

\subsection{Historic installation energy data}

\subsubsection{Purchased utilities consumption data}

In order to track and manage Army energy at the enterprise level, the Army established the Army Energy and Water Reporting System (AEWRS, http://Army-energy.hqda.pentagon.mil/reporting/aewrs.asp). The Army uses AEWRS to collect and compile energy program data for facilitating compliance with federal reporting requirements and assisting with energy management and programming decisions. AEWRS is a repository for monthly Army installation energy consumption data. Each installation is responsible for inputting accurate data each month. Various government offices for energy conservation evaluation and other decision makers can then access this information. Authorized users have access to 30 AEWRS and 15 Energy Manager reports. Reports can be shown for a specific installation, region, Major Command (MACOM), or Army-wide.

Figure 8 is an image of the AEWRS Utilities screen showing monthly energy consumption data for Fort Carson, CO. The data can be exported to Excel for further analysis. Similar monthly utilities data are available for the 144 Army installations currently in the AEWRS database. See Appendix B for the list of installations. 
Figure 8. Image of AEWRS Utilities screen showing monthly energy consumption data by product type for Fort Carson.

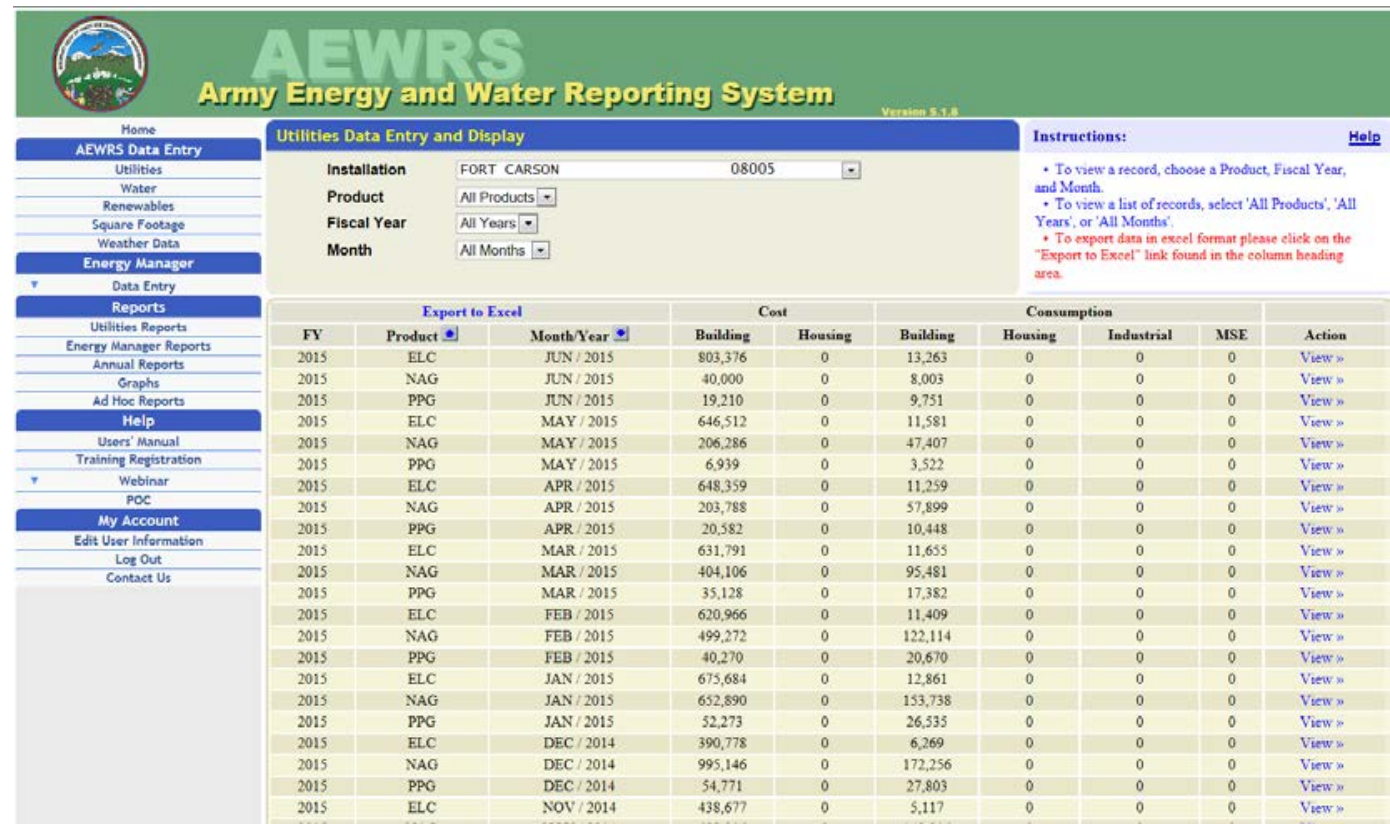

Energy consumption data are reported for electricity, natural gas, propane, fuel oil, and several other energy product types as listed in Table 3.

Table 3. AEWRS utility product codes, reporting units and BTU content.

\begin{tabular}{|l|l|l|l|}
\hline Product Code & Description & AEWRS Reporting Units & $\begin{array}{l}\text { BTU Content } \\
\text { (millions) }\end{array}$ \\
\hline ANC & Coal, anthracite & Short Tons (STON) & 25.4 \\
\hline BDI & Biodiesel & Barrels (BBL) & 5.825 \\
\hline COL & Coal, bituminous & Short Tons (STON) & 24.58 \\
\hline ELC & Electricity & Megawatt Hours (MWH) & 3.412 \\
\hline NAG & Natural Gas & Thousand Cubic Feet (KCF) & 1.031 \\
\hline PPG & Propane/LPG/butane & Gallons (GAL) & 0.0955 \\
\hline SHW & Purchased steam or hot water & Millions of Btu (MMBTU) & 1 \\
\hline FSD1 & Fuel oil-distillate \# & Barrels (BBL) & 5.825 \\
\hline FSR2 & Fuel oil-residual \# & Barrels (BBL) & 6.287 \\
\hline FSX3 & Mixed petroleum \# & Barrels (BBL) & 5.25 \\
\hline WUD4 & Wood & Short Tons (STON) & 17 \\
\hline
\end{tabular}

Installations use a variety of energy product types. Table 4 shows the energy product types currently reported in the AEWRS database for 49 major installations. One can see that all installations used electricity (ELC), the majority used natural gas (NAG), approximately half used propane (PPG) 
or fuel oil-distillate (FSD) and a few installations used coal (COL), wood (WUD) and/or mixed petroleum (FSX).

Table 4. Energy products types reported in the AEWRS Database for $\mathbf{4 9}$ major installations.

\begin{tabular}{|c|c|c|c|c|c|c|c|}
\hline Installation Name & ELC & NAG & PPG & FSD & COL & WUD & FSX \\
\hline ABERDEEN PG & $X$ & $X$ & $x$ & $X$ & - & - & - \\
\hline ANNISTON ARMY DEPOT & $X$ & $x$ & - & - & - & - & - \\
\hline BLUE GRASS ARMY DEPOT & $x$ & $x$ & - & - & - & - & - \\
\hline DUGWAY PROVING GROUND & $\mathrm{X}$ & - & $\mathrm{X}$ & $x$ & - & - & - \\
\hline FORT A P HILL & $x$ & - & $\mathrm{X}$ & $x$ & - & - & - \\
\hline FORT BELVOIR & $x$ & $x$ & - & $x$ & - & - & - \\
\hline FORT BENNING & $\mathrm{X}$ & $X$ & $\mathrm{X}$ & - & - & - & - \\
\hline FORT BLISS & $x$ & $x$ & $x$ & - & - & - & - \\
\hline FORT BRAGG & $X$ & $X$ & $X$ & $X$ & - & - & - \\
\hline FORT BUCHANAN & $X$ & - & $x$ & - & - & - & - \\
\hline FORT CAMPBELL & $x$ & $x$ & $x$ & $x$ & - & - & - \\
\hline FORT CARSON & $X$ & $X$ & $X$ & - & - & - & - \\
\hline FORT DETRICK & $x$ & $x$ & - & - & - & - & - \\
\hline FORT DRUM & $X$ & $X$ & $x$ & - & - & - & - \\
\hline FORT GEORGE MEADE & $X$ & $x$ & - & - & - & - & - \\
\hline FORT GORDON & $x$ & $x$ & $x$ & $x$ & - & - & - \\
\hline FORT GREELY & $\mathrm{X}$ & - & - & $\mathrm{X}$ & - & - & - \\
\hline FORT HAMILTON & $X$ & $X$ & - & $X$ & - & - & - \\
\hline FORT HOOD & $x$ & $x$ & - & - & - & - & - \\
\hline FORT HUACHUCA & $X$ & $X$ & - & - & - & - & - \\
\hline FORT HUNTER LIGGETT & $x$ & $x$ & $x$ & - & - & - & $x$ \\
\hline FORT IRWIN & $x$ & - & $x$ & - & - & - & - \\
\hline FORT JACKSON & $x$ & $x$ & - & - & - & - & - \\
\hline FORT KNOX & $x$ & $x$ & - & - & - & - & - \\
\hline FORT LEAVENWORTH & $x$ & $x$ & - & - & - & - & - \\
\hline FORT LEE & $X$ & $X$ & - & - & - & - & - \\
\hline FORT LEONARD WOOD & $X$ & $X$ & $\mathrm{X}$ & $X$ & - & - & - \\
\hline FORT MCCOY & $x$ & $x$ & $x$ & - & - & - & - \\
\hline FORT POLK & $x$ & $x$ & - & - & - & - & - \\
\hline FORT RILEY & $\mathrm{X}$ & $x$ & $x$ & - & - & - & - \\
\hline FORT RUCKER & $X$ & $x$ & $X$ & $x$ & - & - & - \\
\hline FORT SILL & $X$ & $x$ & - & - & - & - & - \\
\hline FORT STEWART & $x$ & $x$ & $x$ & - & - & - & - \\
\hline FORT WAINWRIGHT & $\mathrm{X}$ & - & - & $\mathrm{X}$ & $x$ & - & - \\
\hline JOINT BASE LEWIS MCCHORD & $X$ & $X$ & - & $\mathrm{X}$ & - & - & - \\
\hline JOINT BASE MYER-HENDERSON HAL & $\mathrm{X}$ & $\mathrm{X}$ & - & - & - & - & - \\
\hline LETTERKENNY ARMY DEPOT & $\mathrm{X}$ & $\mathrm{X}$ & $\mathrm{X}$ & $\mathrm{X}$ & - & - & - \\
\hline PICATINNY ARSENAL & $X$ & $X$ & $X$ & $X$ & - & - & - \\
\hline
\end{tabular}




\begin{tabular}{|c|c|c|c|c|c|c|c|}
\hline Installation Name & ELC & NAG & PPG & FSD & $\mathrm{COL}$ & WUD & FSX \\
\hline PINE BLUFF ARSENAL & $x$ & $x$ & - & - & - & - & - \\
\hline PRESIDIO OF MONTEREY & $x$ & $x$ & - & - & - & - & - \\
\hline PUEBLO CHEMICAL DEPOT & $x$ & $x$ & - & - & - & - & - \\
\hline RED RIVER DEPOT & $x$ & $x$ & - & - & $x$ & $x$ & - \\
\hline REDSTONE ARSENAL & $x$ & $x$ & - & $x$ & - & - & - \\
\hline ROCK ISLAND ARSENAL & $x$ & $x$ & - & - & $x$ & - & - \\
\hline SIERRA ARMY DEPOT & $x$ & $x$ & $x$ & - & - & - & - \\
\hline TOBYHANNA ARMY DEPOT & $x$ & $x$ & $x$ & $x$ & - & - & - \\
\hline TOOELE ARMY DEPOT & $x$ & $x$ & $x$ & $x$ & - & - & - \\
\hline WATERVLIET ARSENAL & $x$ & $x$ & - & $x$ & - & - & - \\
\hline YUMA PROVING GROUND & $x$ & - & $x$ & $x$ & - & - & - \\
\hline TOTALS & 49 & 42 & 24 & 20 & 3 & 1 & 1 \\
\hline
\end{tabular}

Army policy excludes consideration of any energy-consumption data for privately owned properties (e.g., those constructed through Residential Communities Initiative) in installation performance measurements reported through the Redesigned Army Defense Utility Energy Reporting System Data System (RADDS) system. Per the OASA (IE\&E) funded document "A History of the U.S. Army's Residential Communities Initiative, 1995-2010" (Godfrey 2012), in 2010, nearly all Army family housing in the United States (except for some homes at very small installations) was privatized. As a result, energy consumption data reported in the AEWRS database excludes energy consumed by family housing units.

For current purposes, only unreimbursed building energy consumption data were analyzed. The following categories of energy-consumption data were not considered in our analysis:

- Family housing

- Industrial

- Mobilization Substitution Energy (MSE)*

- Optional BTUs

- Reimbursed building consumption

\footnotetext{
* Mobility substitution energy is defined as the facilities' energy that directly substitutes for mobility energy to achieve greater efficiency. Examples include cold iron ships support, aircraft, ship and weapons systems (e.g., tanks), simulator energy use, and central flight line aircraft power systems. Energy reported in these categories should be directly metered. Since the use of mobility substitution energy improves the overall energy efficiency of Defense energy usage, and improves readiness training and weapon system maintenance, increasing the use of it should be actively encouraged. Mobility substitution energy is to be reported at each activity using a separate Department of Defense Activity Address Code (DoDAAC).
} 
- Reimbursed industrial consumption

- Reimbursed MSE consumption

It was assumed that monthly energy consumption numbers were accurate, reliable data since these reported numbers were presumably taken directly from monthly utility bills. It is possible that occasionally monthly consumption numbers for electricity or natural gas might be based on estimates rather than actual meter readings. For purposes of this study, that possibility should not cause concern since it probably occurs quite infrequently and any estimated consumption numbers would probably be based on historic consumption from the same month in a previous year.

It should be noted that unlike electricity (ELC) or natural gas (NAG) which are delivered continuously, other energy product types are delivered in bulk shipments, presumably, on an as-needed basis. As a result, for certain months of the year, the AEWRS database often displays a null entry or zero consumption for products such as propane (PPG), fuel oil (FSD) and other product types. A null entry or a zero displayed for a given month for a particular product type doesn't necessarily mean that that product was not used for that month. More likely, it means that not enough of that product was used to require the installation to place an order for delivery of that product during the reporting period. Nevertheless, some quantity of that product type may have been used during months with null entries or zero entries in the AEWRS database. Shaded cells in Figure 9 shows months for which Fort Bliss entered no data or reported zero usage of propane (PPG).

It might seem that null entries or zero entries in the AEWRS database would pose a problem in our analysis if, in fact, some of that particular product type were actually consumed in a given month. After considering this, we realized that generally products that had null or zero monthly consumption entries in the AEWRS database were usually somewhat insignificant in the installation's overall utility profile. For example, as seen in Figure 9, the highest usage of propane (PPG) over the past two years never exceeded $3 \%$ of the installation's total energy usage. As a result, propane usage at Fort Bliss is relatively insignificant in the installation's overall energy portfolio, and there is no compelling need to try to adjust or correct the data to account for the fact that some quantity of propane was almost certainly used during months of zero reported usage. 
Figure 9. Two years of reported building energy data for Fort Bliss.

\begin{tabular}{|c|c|c|c|c|c|c|c|}
\hline Month/Year & $\begin{array}{c}\text { Building } \\
\text { Consumption } \\
\text { ELC (MMBTU) }\end{array}$ & $\begin{array}{c}\text { Building } \\
\text { Consumption } \\
\text { NAG (MMBTU) }\end{array}$ & $\begin{array}{c}\text { Building } \\
\text { Consumption } \\
\text { PPG (MMBTU) }\end{array}$ & $\begin{array}{l}\text { Total Building } \\
\text { Consumption } \\
\text { (MMBTU) }\end{array}$ & $\%$ ELC & $\%$ NAG & $\%$ PPG \\
\hline Jul/2016 & 90,681 & 16,676 & & 107,357 & 84.47 & 15.53 & 0.00 \\
\hline Jun/2016 & 89,551 & 16,001 & 0 & 105,552 & 84.84 & 15.16 & 0.00 \\
\hline May/2016 & 66,732 & 18,404 & 0 & 85,136 & 78.38 & 21.62 & 0.00 \\
\hline Apr/2016 & 62,351 & 31,802 & 0 & 94,153 & 66.22 & 33.78 & 0.00 \\
\hline Mar/2016 & 59,430 & 36,799 & 1,035 & 97,264 & 61.10 & 37.83 & 1.06 \\
\hline $\mathrm{Feb} / 2016$ & 73,314 & 82,823 & 1,068 & 157,205 & 46.64 & 52.69 & 0.68 \\
\hline $\operatorname{Jan} / 2016$ & 70,611 & 106,738 & 1,713 & 179,063 & 39.43 & 59.61 & 0.96 \\
\hline $\mathrm{Dec} / 2015$ & 55,974 & 98,558 & 2,064 & 156,596 & 35.74 & 62.94 & 1.32 \\
\hline Nov/2015 & 71,594 & 43,368 & 524 & 115,486 & 61.99 & 37.55 & 0.45 \\
\hline Oct/2015 & 73,918 & 19,374 & 238 & 93,529 & 79.03 & 20.71 & 0.25 \\
\hline Sep/2015 & 85,628 & 17,760 & 235 & 103,622 & 82.63 & 17.14 & 0.23 \\
\hline Aug/2015 & 99,723 & 14,966 & 0 & 114,689 & 86.95 & 13.05 & 0.00 \\
\hline Jul/2015 & 85,593 & 15,659 & 0 & 101,252 & 84.53 & 15.47 & 0.00 \\
\hline Jun/2015 & 88,309 & 15,808 & 0 & 104,118 & 84.82 & 15.18 & 0.00 \\
\hline May/2015 & 59,454 & 23,011 & 0 & 82,465 & 72.10 & 27.90 & 0.00 \\
\hline Apr/2015 & 63,665 & 27,048 & 1,194 & 91,907 & 69.27 & 29.43 & 1.30 \\
\hline Mar/2015 & 61,750 & 61,530 & 1,095 & 124,376 & 49.65 & 49.47 & 0.88 \\
\hline $\mathrm{Feb} / 2015$ & 58,601 & 77,846 & 1,493 & 137,939 & 42.48 & 56.43 & 1.08 \\
\hline $\operatorname{Jan} / 2015$ & 83,410 & 109,490 & 3,252 & 196,152 & 42.52 & 55.82 & 1.66 \\
\hline $\mathrm{Dec} / 2014$ & 54,954 & 89,213 & 3,602 & 147,769 & 37.19 & 60.37 & 2.44 \\
\hline Nov/2014 & 68,605 & 49,251 & 3,602 & 121,457 & 56.48 & 40.55 & 2.97 \\
\hline Oct/2014 & 69,100 & 20,877 & 0 & 89,977 & 76.80 & 23.20 & 0.00 \\
\hline Sep/2014 & 86,214 & 18,658 & 497 & 105,370 & 81.82 & 17.71 & 0.47 \\
\hline Aug/2014 & 94,615 & 15,624 & & 110,239 & 85.83 & 14.17 & 0.00 \\
\hline
\end{tabular}

\subsubsection{Installation energy cost data}

In addition to monthly installation energy consumption data, Energy Managers also populate AEWRS with monthly energy cost data, by Product Code. The first three columns of Table 5 lists energy cost data reported for Fort Bragg for March 2015. The last three columns were calculated based on the reported data.

Table 5. Fort Bragg energy cost data reported in AEWRS for March 2015.

\begin{tabular}{|l|l|l|l|l|l|l|}
\hline Product & Building Cost & $\begin{array}{l}\text { Building } \\
\text { Consumption }\end{array}$ & $\begin{array}{l}\text { Reporting } \\
\text { Units }\end{array}$ & $\begin{array}{l}\text { Unit Cost per } \\
\text { Reporting Unit }\end{array}$ & MMBTU & $\begin{array}{l}\text { Cost per } \\
\text { MMBTU }\end{array}$ \\
\hline ELC & $\$ 2,577,393$ & 43,594 & MWH & $\$ 59.12$ & 148,743 & $\$ 17.33$ \\
\hline FSD & $\$ 227,918$ & 1,491 & BBL & $\$ 152.86$ & 8,685 & $\$ 26.24$ \\
\hline NAG & $\$ 1,015,531$ & 200,922 & KCF & $\$ 5.05$ & 207,151 & $\$ 4.90$ \\
\hline PPG & $\$ 47,453$ & 34,892 & GAL & $\$ 1.36$ & 3,332 & $\$ 14.24$ \\
\hline TOTAL & $\$ 3,868,295$ & & & & 367,911 & \\
\hline
\end{tabular}


Although we were able to extract historic utility cost data from the AEWRS database, we did not have confidence that we could project utility unit costs. As a result, it was decided to develop projections of climate change impacts on installation energy usage and forego projecting future installation energy costs.

\subsubsection{Renewable energy data}

Figure 10 is an image of the AEWRS Renewables screen showing the capacity of various renewable energy sources supporting Fort Carson, CO. The data can be exported to Excel for further analysis. By clicking on the "View >> " link under the "Action" column on the right side of the screen, detailed information about each renewable energy resource can be found. Similar renewables data are available for the 144 other Army installations in the AEWRS database.

Figure 10. Image of AEWRS Renewables screen showing renewable energy resources for Fort Carson.

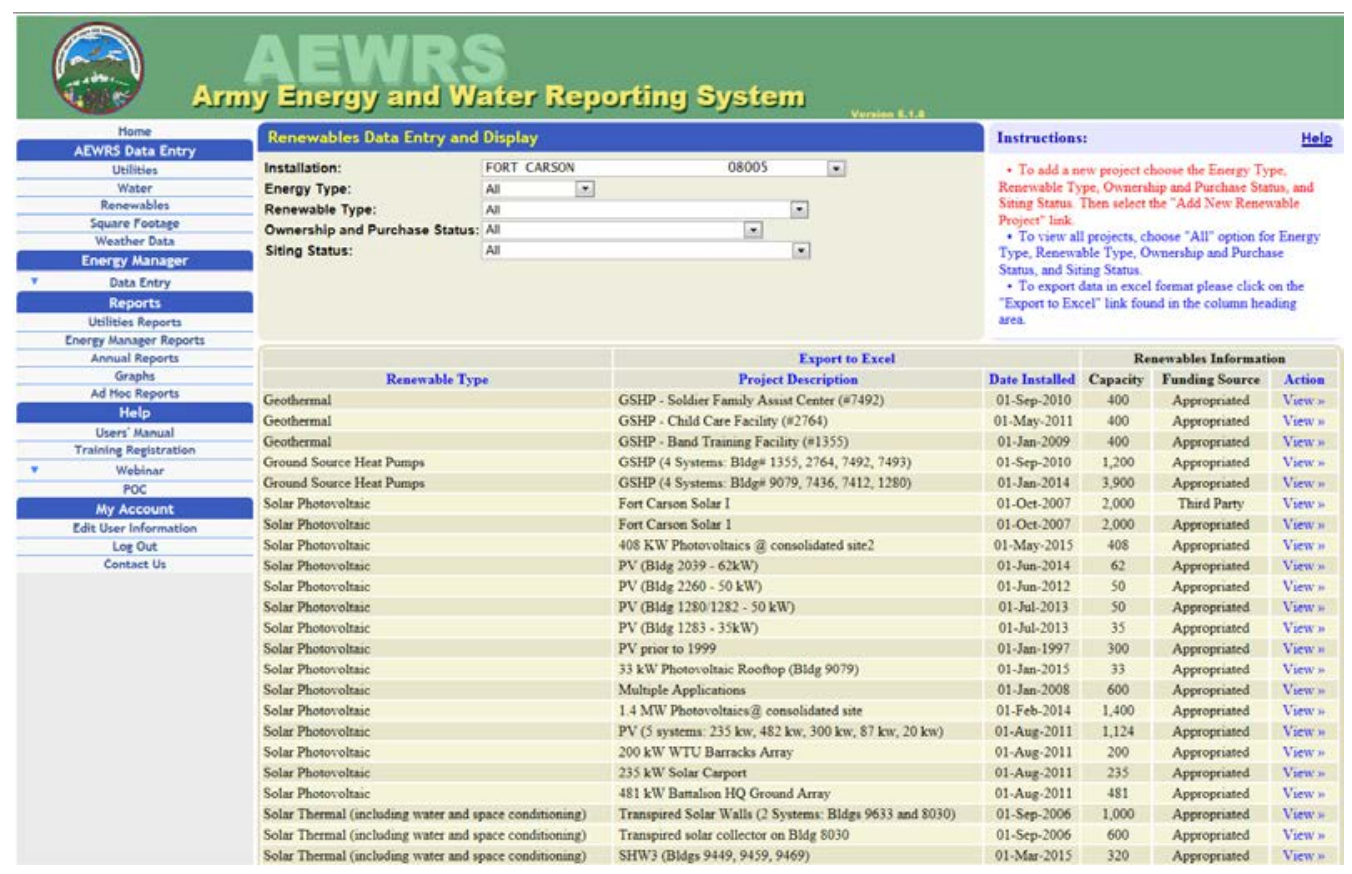

Since the AEWRS Renewables screen shows renewable energy capacity but does not provide actual monthly renewable energy production or consumption, it is necessary to click on "View" in the "Action" column of the Renewables screen shown in Figure 10 above to obtain quarterly reported values for each of the renewable energy systems shown on the Renewables 
screen. This is a very tedious process, especially for large installations such as Fort Carson with numerous renewable energy systems.

The output of non-electrical renewable energy sources is also typically estimated using some generally accepted estimation method. For example, the output of solar hot water panels can be estimated by multiplying the average annual solar insolation on the surface of the panel (MMBTU/SF/year) times the panel's surface area times an assumed system efficiency (typically, about 70\%). Simple estimation methods are also available for other renewable energy technologies such as ground source heat pumps, biomass, transpired solar walls, etc. Since renewable energy outputs are reported on a quarterly basis (for both metered and estimated renewable energy sources), monthly outputs are assumed to be equal to quarterly outputs divided by three.

As noted in section 3.4.1, after an initial consideration of the potential impacts of climate change on renewable energy utilization (see Appendix A) the research team decided that there were too many variables and imponderables to reach a firm conclusion. However, our investigation did make it clear that installation renewable energy capacity can be expected to increase for the foreseeable future, but the rate of increase is expected to be dependent on policy, budgets, energy markets, and factors other than climate change.

\subsection{Historic installation square footage data}

The AEWRS database is also used to track the square footage of installation buildings. All square footage data is imported from Headquarters, Department of Army (HQDA) Installation Information System (HQIIS) on a quarterly basis. Imported data are in read-only format. Data imported from HQIIS excludes the following [AEWRS User Manual, May 2015]:

- Commissaries

- Leased buildings (where Army does not pay for the utilities)

- Privatized housing (Residential Communities Initiative)

- Non-government (non-federal) tenants

Figure 11 shows the square footage screen for Fort Carson, including the number and square footage of buildings, relocatables, and family housing. 
Figure 11. Image of AEWRS Square Footage screen showing square footage data for Fort Carson facilities.

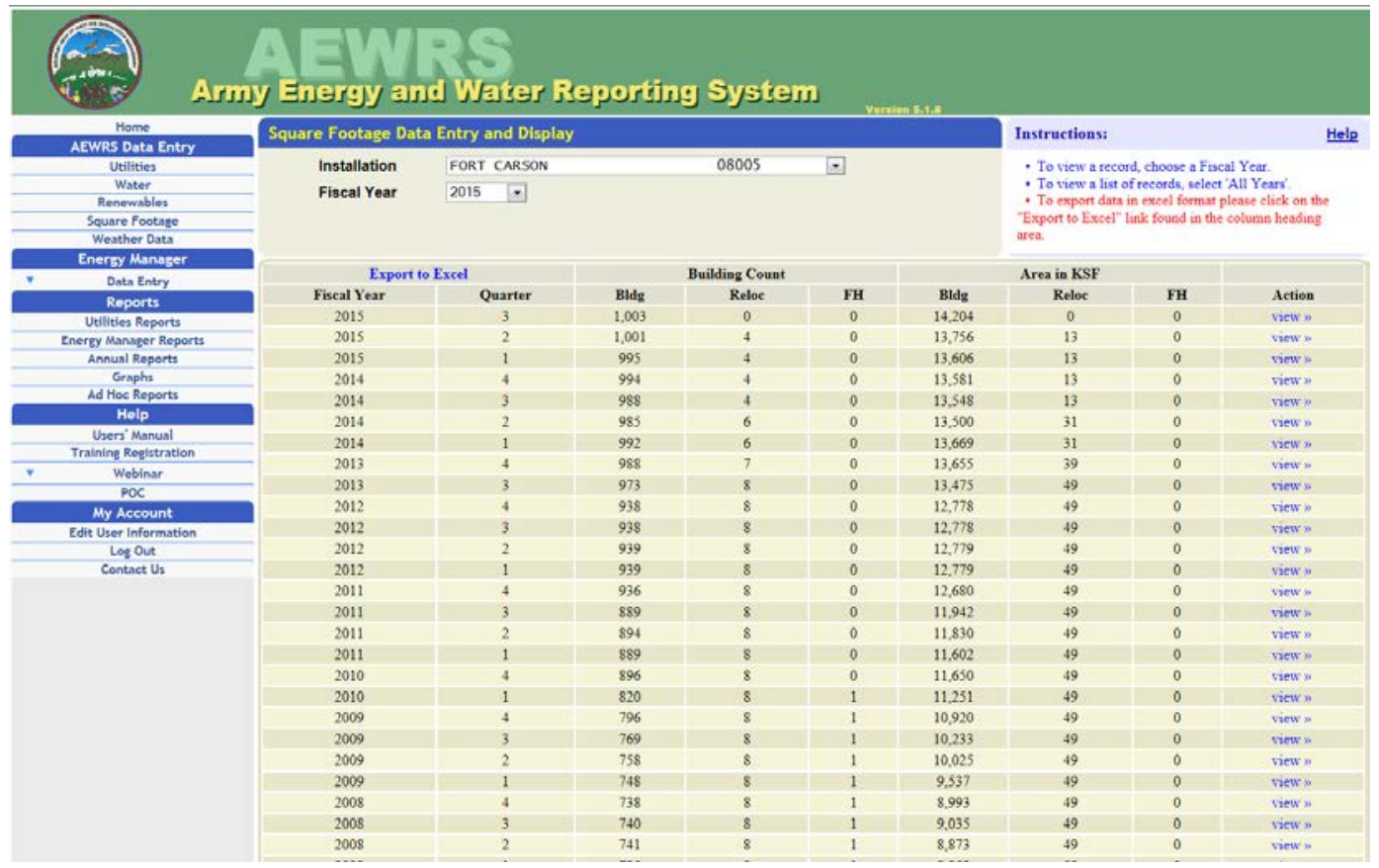

These data can be exported to Excel for further analysis. By clicking on the "View >>" link under the "Action" column on the right side of the screen, detailed historic information about the installation's buildings inventory including number of buildings, real property category codes, building numbers, square footage of different buildings, etc., can be found. If desired, building-by-building details of the imported data can be viewed by clicking on the "View Building Square footage details in Excel" found under each Quarter tab. Similar square footage data is available for the 144 other Army installations currently in the AEWRS database.

For current purposes, we only concerned ourselves with "Building KSF" and "Relocatable KSF" square footage data. The following square footage data were not used:

- Family Housing KSF

- Industrial KSF

- MSE KSF (Mobility Substitution Energy)

As seen in Figure 12, the square footage of Fort Carson's buildings increased significantly from the end of 2008 but has been relatively stable since the end of 2013. For Fort Carson, the Total KSF includes the square 
footage of both buildings and relocatables. It does not include any family housing facilities or industrial facilities.

Figure 12. Fort Carson square footage data as reported in AEWRS.

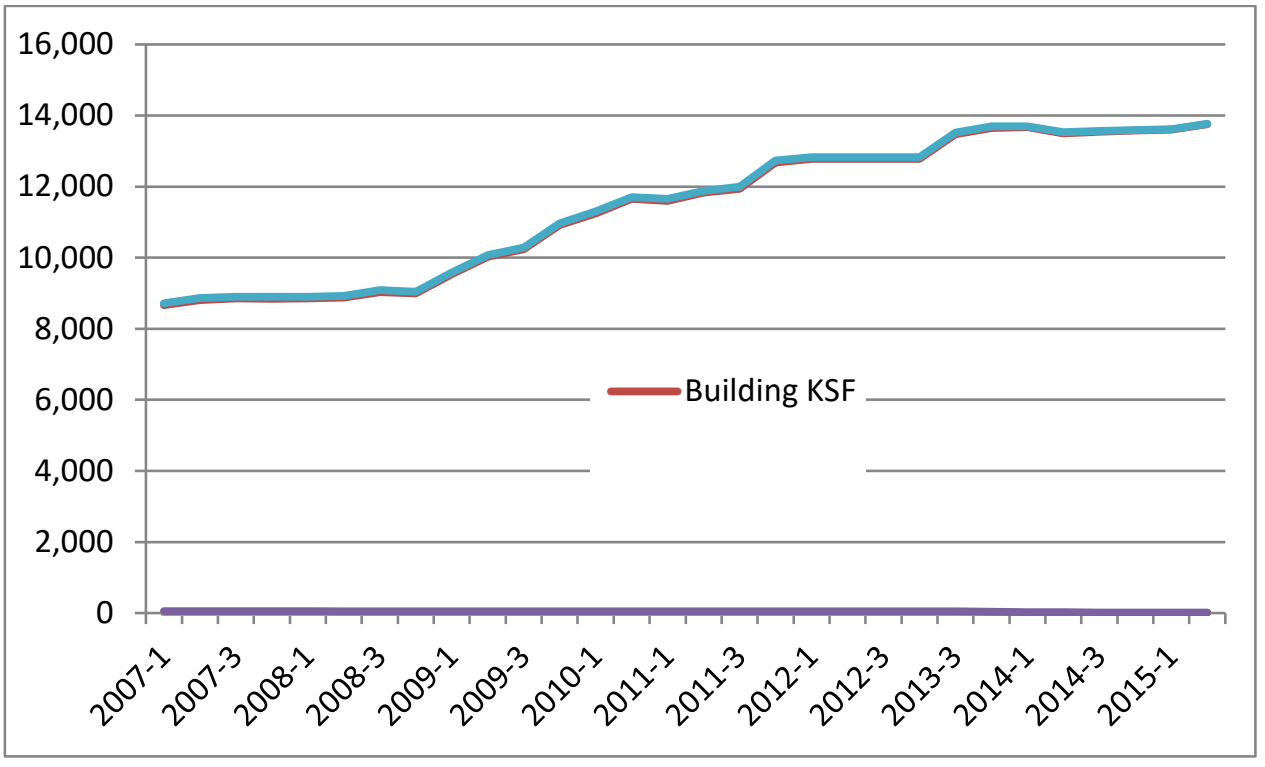

\subsection{Historic installation weather data}

\subsubsection{AEWRS weather data}

Figure 13 is an image of the AEWRS Weather Data screen showing historic monthly heating degree days and cooling degree days. These data can be exported to Excel for further analysis. Similar weather data are available for the 144 other Army installations currently in the AEWRS database. 
Figure 13. Image of AEWRS Weather Data screen showing monthly heating degree days and cooling degree days for Fort Carson facilities.

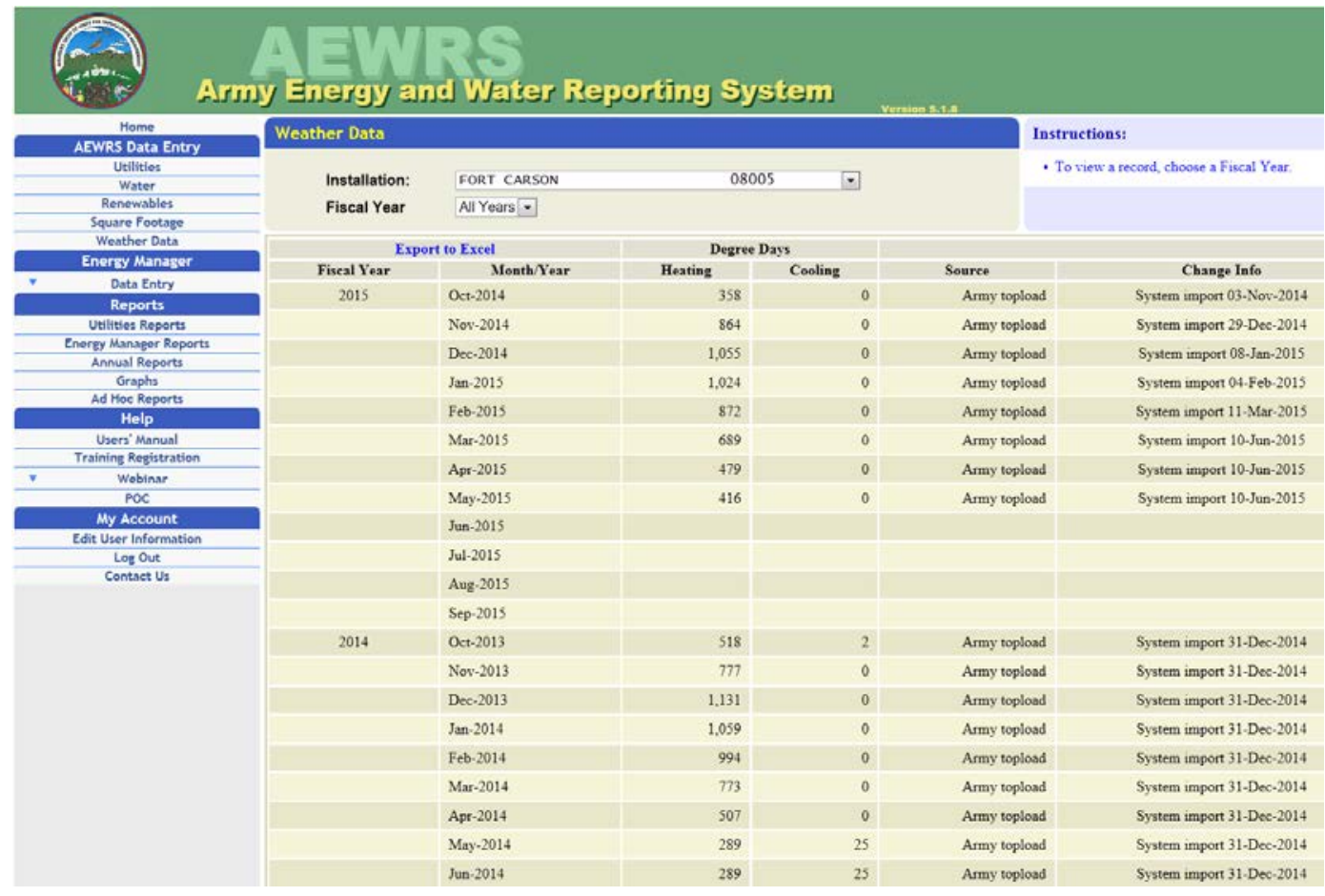

Although heating degree days and cooling degree days are useful for some purposes, we sought sources of monthly average temperature data from other sources to provide a single monthly temperature value that could be more easily related to a single monthly utility usage data point.

\subsubsection{Airfield METAR data}

Meteorological data is collected at specific locations referred to as observing sites, observing stations or simply stations. Stations are identified by a five-digit index number assigned by the World Meteorological Organization (WMO) and/or a four-character International Civil Aviation Organization (ICAO) location indicator. Stations bearing an ICAO location indicator are typically located at or near an airport.

Many Army installations include an airfield or are located relatively close to an airport that measures, records, and archives local weather data. Accessing weather data for a given Army installation can be accomplished by finding the nearest WMO or ICAO weather station and querying that station for the data of interest. 
In the continental United States (excluding Alaska and Hawaii) ICAO location indicators usually consist of a prefix of "K" followed by the three-character International Air Transport Association (IATA) or Federal Aviation Administration (FAA) designator for the referenced airport. IATA codes are listed where applicable. Cities shown are those associated with the airport as per the FAA, this may not always be the exact location as airports are often located in smaller towns outside the cities they serve. See http://www.airport-data.com/world-airports/icao-code/K.html for a complete listing of U.S. airports listed by ICAO Code: $\mathrm{K}$.

With an ICAO code for an airport of interest, one can access current METAR data for that airport. "METAR is the international standard code format for hourly surface weather observations. The acronym roughly translates from French as Aviation Routine Weather Report." (https://www.ncdc.noaa.gov/wdc/metar/index.php?name=faq, accessed Feb 7, 2017.)

An example of a METAR datum is shown below:

KAUS 092135Z 26018G25KT 8SM -TSRA BR SCTo45CB BKNo6o OVCo80 30/21 A2992 RMK FQT LTGICCCCG OHD-W MOVG E RAB25 TSB32 CB ALQDS SLP132 Poo35 To3020210 =

This character string encodes, among other things, the following information:

KAUS - Austin Bergstrom International Airport

092135Z - Date/Time Group. "09" is the day of month... "2135Z" is Greenwich Time or 3:35 pm CT

26018G25KT - Wind Group. Direction is "260 degrees" (west wind)... at 18 gusting to 25 knots (multiply by

1.15 to get speed in miles per hour)

8SM - Visibility (8 statute miles)

-TSRA BR - Current Weather type/Obscurations to Visibility... In this case, thunderstorm and light rain... mist

Some other commonly used abbreviations:

FG (Fog) GR (Hail) SN (Snow) 


\author{
FZRA (Freezing Rain) FZDZ (Freezing Drizzle) RA (Rain) TS \\ (T'Storm, no rain) PL (Ice Pellets) DZ (Drizzle) \\ VCTS (T'Storm in the Vicinity) \\ (http://www.la.utexas.edu/users/kimmel/GRG301K/grg301kmetars.ht \\ $\underline{\mathrm{ml}}$, accessed Feb 7, 2017).
}

METARs are primarily for the benefit of the aviation community and are broadcast several times per day, often approximately at hourly intervals. A sample METAR for Fort Hood, Robert Gray AAF (ICAO code KGRK) for 13:58 UTC (o8:58 a.m. CDT) on 7 Oct 2016 was:

\begin{abstract}
KGRK 071358Z AUTO 03012KT 4SM -RA BR BKNoo9 BKNo14 OVCo38 20/19 A3008 RMK AO2 VIS 2 RWY15 RAEooRAB12E20RAB46 SLP178 Poooo To2000188 (http://www.aviatorjoe.net/go/wx/KGRK/, accessed 7 Oct 2016.)
\end{abstract}

The pertinent data of interest in this project are:

- KGRK - the ICAO code for Fort Hood Robert Gray AAF

- $071358 Z$ - Indicates the 7th day of the month at 13:58 UTC (8:58 a.m., local time)

- $20 / 19-$ Dry bulb temperature $=20^{\circ} \mathrm{C}\left(68^{\circ} \mathrm{F}\right)$; dew point temperature $=19^{\circ} \mathrm{C}\left(66^{\circ} \mathrm{F}\right)$

One can easily find current METAR data for an airport of interest on the internet. For example a web search on "METAR KFDK" will locate several sources of current METAR data for the Frederick Municipal Airport. The following are 24 hours of METAR data for Frederick Municipal Airport (ICAO code: KDFK, Frederick, MD) for 7 Oct 2016:

Data at: 1446 UTC 07 Oct 2016

KFDK 071349Z 08004KT 10SM OVCo10 16/16 A3029

KFDK 071247Z 01006KT 10SM BKNo12 OVCo9o 16/16 A3031

KFDK 071147Z 04005KT 10SM BKNo90 14/14 A3030

KFDK 071046Z oooooKT 10SM BKNo9o 13/13 A3028

KFDK 062347Z 16003KT 10SM CLR 16/16 A3030

KFDK 062247Z 0000oKT 10SM SCTo65 19/17 A3029

KFDK 062150Z o000oKT 10SM CLR 21/16 A3030

KFDK 062047Z o000oKT 10SM CLR 22/16 A3029 
KFDK 061947Z o000oKT 10SM CLR 21/15 A3030

KFDK 061847Z 32003KT 10SM SCTo27 SCTo50 21/15 A3032

KFDK 061745Z 05005KT 10SM OVCo25 19/15 A3033

KFDK 061647Z 35004KT 10SM HZ SCTo16 OVCo25 18/15 A3034

KFDK 061547Z 01007KT 5SM BR BKNoo7 OVC025 16/16 A3035

KFDK 061447Z 02006KT 2 1/2SM BR OVCoo5 13/13 A3006

(http://www.aviationweather.gov/metar/data?ids=KFDK\&format=raw\& date $=0$ \&hours $=24$, accessed 7 Oct 2016).

The data shown above would need to be processed by parsing out the dry bulb temperature data, converting from Celsius to Fahrenheit, then calculating a daily average temperature by summing the individual METAR temperatures and dividing by the number of METARs for that day. For the case of Frederick Municipal Airport on 7 Oct 2016, the average daily temperature would be $17.5^{\circ} \mathrm{C}\left(63.5^{\circ} \mathrm{F}\right)$.

METAR data tend to be readily available as current data or historic data for one or two days. Accessing historic METAR data for past months or years is not a straightforward task. Although it is possible to write a script to query various METAR data sites to access historic data, this can be difficult for those who are unfamiliar with writing scripts.

\subsubsection{Global surface summary of the day data}

A more user-friendly source of historic installation weather data is Global Surface Summary of the Day (GSOD) data. These data are available for many airports throughout the U.S. and can be downloaded as comma-delimited text files.

The data shown in Figure 14 provide daily averages of various weather parameters, including dry bulb, dew point temperatures, and more. For our purposes, the data of interest are highlighted in yellow, including the date, the average daily dry bulb temperature $\left({ }^{\circ} \mathrm{F}\right)$ and the number of measurements included in that average. 
Figure 14. Sample of GSOD data for Fort Hood from April 1 to May 1, 2015.

\begin{tabular}{|c|c|c|c|c|c|c|c|c|c|c|c|c|c|c|c|c|c|c|c|c|c|c|}
\hline 4 & A & B & c & D & $\mathrm{E}$ & $\mathrm{F}$ & G & $\mathrm{H}$ & I & J & K & L & M & $\mathrm{N}$ & 0 & P & Q & $\mathrm{R}$ & $s$ & $T$ & u & v \\
\hline 1 & STN--- & WBAN & YEARMODA & TEMP & & DEWP & & SLP & & STP & & VISIB & & WDSP & & MXSPD & GUST & MAX & MIN & PRCP & SNDP & FRSHTT \\
\hline 443 & 722680 & 23009 & 20150401 & 66.9 & 24 & 37.6 & 24 & 1006.6 & 24 & 884.5 & 24 & 10 & 24 & 5.9 & 24 & 18.1 & 22 & 86 & 44.1 & $0.00 G$ & 999.9 & 0 \\
\hline 444 & 722680 & 23009 & 20150402 & 68.2 & 24 & 27.7 & 24 & 1005.6 & 24 & 883.9 & 24 & 10 & 24 & 9 & 24 & 19 & 22 & 88 & 46 & $0.00 \mathrm{G}$ & 999.9 & 0 \\
\hline 445 & 5722680 & 23009 & 20150403 & 58.8 & 24 & 25.2 & 24 & 1013.8 & 23 & 890.5 & 24 & 9.6 & 24 & 9.5 & 24 & 19 & 25.1 & $84.0^{*}$ & $44.6^{*}$ & $0.00 \mathrm{G}$ & 999.9 & 0 \\
\hline 446 & 722680 & 23009 & 20150404 & 52.6 & 24 & 30.4 & 24 & 1023.3 & 24 & 897.6 & 24 & 10 & 24 & 7.6 & 24 & 15 & 21 & 66 & 39 & $0.00 \mathrm{G}$ & 999.9 & 0 \\
\hline 447 & 722680 & 23009 & 20150405 & 55.4 & 24 & 33.9 & 24 & 1012.3 & 24 & 887.9 & 24 & 10 & 24 & 6 & 24 & 17.1 & 22 & 82.9 & 39 & $0.00 \mathrm{G}$ & 999.9 & 0 \\
\hline 448 & 3722680 & 23009 & 20150406 & 65.8 & 24 & 25.6 & 24 & 1006.2 & 24 & 884 & 24 & 10 & 24 & 8.7 & 24 & 20 & 32.1 & 88 & 39 & $0.00 \mathrm{G}$ & 999.9 & 0 \\
\hline 449 & 722680 & 23009 & 20150407 & 65.8 & 24 & 24.9 & 24 & 1007.8 & 24 & 885.5 & 24 & 10 & 24 & 7.8 & 24 & 15.9 & 24.1 & 89.1 & 42.1 & $0.00 \mathrm{G}$ & 999.9 & 0 \\
\hline 450 & 722680 & 23009 & 20150408 & 69.5 & 24 & 29.3 & 24 & 1005.4 & 24 & 883.9 & 24 & 10 & 24 & 11.9 & 24 & 27 & 38.1 & 89.1 & 42.1 & $0.00 \mathrm{G}$ & 999.9 & 0 \\
\hline 451 & 1. 722680 & 23009 & 20150409 & 63.1 & 24 & 17.8 & 24 & 1006.4 & 24 & 884.4 & 24 & 10 & 24 & 8.7 & 24 & 18.1 & 999.9 & 88 & 45 & $0.00 \mathrm{G}$ & 999.9 & 0 \\
\hline 452 & 722680 & 23009 & 20150410 & 58.6 & 24 & 29 & 24 & 1015.6 & 24 & 891.8 & 24 & 10 & 24 & 6.2 & 24 & 15 & 20 & 75.9 & 45 & $0.00 \mathrm{G}$ & 999.9 & 0 \\
\hline 453 & 722680 & 23009 & 20150411 & 65 & 24 & 39.9 & 24 & 1010.7 & 23 & 887.6 & 24 & 10 & 24 & 6.7 & 24 & 15.9 & 24.1 & 87.1 & 45 & $0.00 \mathrm{G}$ & 999.9 & 0 \\
\hline 454 & +722680 & 23009 & 20150412 & 67.1 & 24 & 34.2 & 24 & 1005.3 & 24 & 883.5 & 24 & 10 & 24 & 8.4 & 24 & 15.9 & 25.1 & 87.1 & 46 & $0.00 G$ & 999.9 & 10000 \\
\hline 455 & 722680 & 23009 & 20150413 & 54.3 & 24 & 49.3 & 24 & 1011.4 & 20 & 888.3 & 24 & 7.8 & 24 & 11.6 & 24 & 22 & 31.1 & $59.0^{*}$ & $50.0^{*}$ & $0.92 \mathrm{G}$ & 999.9 & 10000 \\
\hline 456 & 722680 & 23009 & 20150414 & 52 & 24 & 39.7 & 24 & 1020.7 & 24 & 895.1 & 24 & 10 & 24 & 4.9 & 24 & 14 & 18.1 & 68 & 39 & $0.80 \mathrm{G}$ & 999.9 & 10000 \\
\hline 457 & 722680 & 23009 & 20150415 & 60.3 & 24 & 40.9 & 24 & 1009.3 & 24 & 885.9 & 24 & 9.9 & 24 & 11.6 & 24 & 21 & 29.9 & 81 & 39 & $0.00 \mathrm{G}$ & 999.9 & 0 \\
\hline 458 & 322680 & 23009 & 20150416 & 65.2 & 24 & 37.1 & 24 & 1004.8 & 24 & 882.9 & 24 & 10 & 24 & 13.3 & 24 & 27 & 34 & 81 & 45 & $0.00 \mathrm{G}$ & 999.9 & 0 \\
\hline 459 & 722680 & 23009 & 20150417 & 58.7 & 24 & 18.6 & 24 & 1010.3 & 24 & 887.3 & 24 & 10 & 24 & 11 & 24 & 24.1 & 34 & 78.1 & 42.1 & $0.00 \mathrm{G}$ & 999.9 & 0 \\
\hline 460 & 722680 & 23009 & 20150418 & 56.7 & 24 & 25.2 & 24 & 1010.2 & 24 & 886.5 & 24 & 10 & 24 & 6.8 & 24 & 15 & 24.1 & 77 & 36 & $0.00 \mathrm{G}$ & 999.9 & 0 \\
\hline 461 & 1. 722680 & 23009 & 20150419 & 60.1 & 24 & 30.4 & 24 & 1009 & 24 & 886 & 24 & 10 & 24 & 8.9 & 24 & 14 & 15.9 & 77 & 36 & $0.00 \mathrm{G}$ & 999.9 & 0 \\
\hline 462 & 722680 & 23009 & 20150420 & 56.8 & 24 & 36.9 & 24 & 1012.1 & 24 & 888.3 & 24 & 10 & 24 & 9 & 24 & 17.1 & 22.9 & 73.9 & 42.1 & $0.00 \mathrm{G}$ & 999.9 & 0 \\
\hline 463 & 722680 & 23009 & 20150421 & 61.7 & 24 & 39.7 & 24 & 1008.5 & 24 & 885.6 & 24 & 10 & 24 & 6.8 & 24 & 17.1 & 999.9 & 81 & 42.1 & $0.00 \mathrm{G}$ & 999.9 & 0 \\
\hline 464 & +722680 & 23009 & 20150422 & 65 & 24 & 36 & 24 & 1005.8 & 24 & 883.8 & 24 & 9.7 & 24 & 5.1 & 24 & 9.9 & 999.9 & 84.9 & 44.1 & $0.00 \mathrm{G}$ & 999.9 & 0 \\
\hline 465 & 722680 & 23009 & 20150423 & 63.8 & 24 & 27.1 & 24 & 1006.7 & 24 & 884.4 & 24 & 10 & 24 & 9.3 & 24 & 24.1 & 31.1 & 84.9 & 45 & $0.00 \mathrm{G}$ & 999.9 & 0 \\
\hline 466 & 722680 & 23009 & 20150424 & 65.8 & 24 & 34.5 & 24 & 1004.7 & 24 & 882.9 & 24 & 10 & 24 & 13.1 & 24 & 22.9 & 33 & 80.1 & 46 & $0.00 \mathrm{G}$ & 999.9 & 0 \\
\hline 467 & 722680 & 23009 & 20150425 & 63.4 & 24 & 30.5 & 24 & 1005.8 & 24 & 883.5 & 24 & 10 & 24 & 8.4 & 24 & 20 & 26 & 81 & 48 & $0.00 \mathrm{G}$ & 999.9 & 0 \\
\hline 468 & 722680 & 23009 & 20150426 & 62.6 & 24 & 26.9 & 24 & 1000.9 & 24 & 879.3 & 24 & 9.9 & 24 & 12.1 & 24 & 28.9 & 41 & 81 & 46 & $0.00 \mathrm{G}$ & 999.9 & 0 \\
\hline 469 & 722680 & 23009 & 20150427 & 53.9 & 24 & 39.7 & 24 & 1007.4 & 23 & 883.8 & 24 & 9.9 & 24 & 13.9 & 24 & 24.1 & 29.9 & 73 & 46 & $0.00 \mathrm{G}$ & 999.9 & 10000 \\
\hline 470 & 722680 & 23009 & 20150428 & 52.6 & 24 & 33 & 24 & 1020.9 & 24 & 895.2 & 24 & 10 & 24 & 11.2 & 24 & 17.1 & 25.1 & 70 & 42.1 & $0.02 \mathrm{G}$ & 999.9 & 0 \\
\hline 471 & 722680 & 23009 & 20150429 & 56.9 & 24 & 31.2 & 24 & 1018 & 24 & 893.3 & 24 & 10 & 24 & 5 & 24 & 15 & 19 & 77 & 39 & $0.00 \mathrm{G}$ & 999.9 & 0 \\
\hline 472 & 722680 & 23009 & 20150430 & 62.6 & 24 & 29.1 & 24 & 1010.8 & 24 & 887.7 & 24 & 10 & 24 & 5.6 & 24 & 15 & 21 & 86 & 39 & $0.00 \mathrm{G}$ & 999.9 & 0 \\
\hline 473 & 722680 & 23009 & 20150501 & 67.3 & 24 & 30.9 & 24 & 1010.1 & 24 & 887.8 & 24 & 10 & 24 & 7.4 & 24 & 15 & 22 & 88 & 41 & $0.00 \mathrm{G}$ & 999.9 & 0 \\
\hline
\end{tabular}

A convenient source of GSOD data is NNDC Climate Data Online, at http://www7.ncdc.noaa.gov/CDO/cdoselect.cmd?datasetabbv=GSOD\&res olution=40. Figure 15 is a screen capture of the main page of this site.

To access GSOD data for a location of interest, follow the procedure provided in Appendix C. 
Figure 15. Global Summary of the Day (GSOD) on NNDC Climate Data Online.

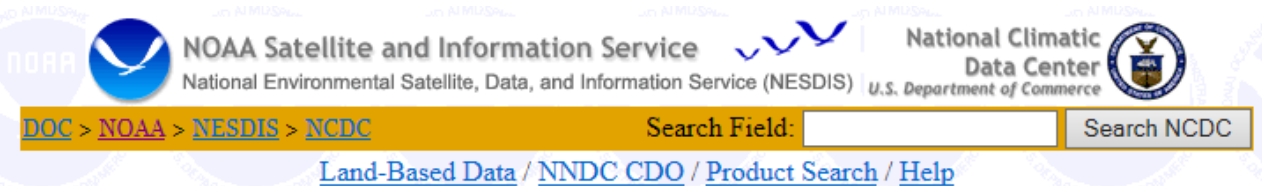

Land-Based Data / NNDC CDO / Product Search / Help

\section{NNDC CLIMATE DATA ONLINE}

Global Summary of the Day (GSOD)

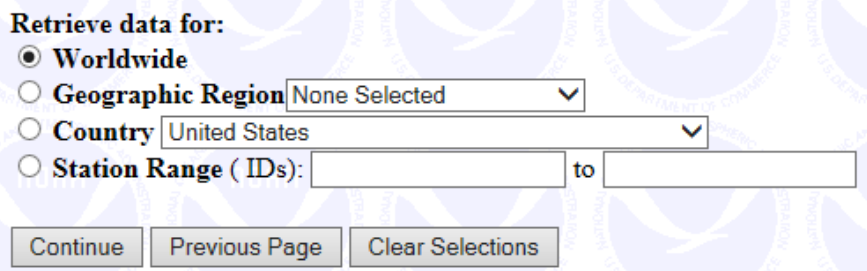

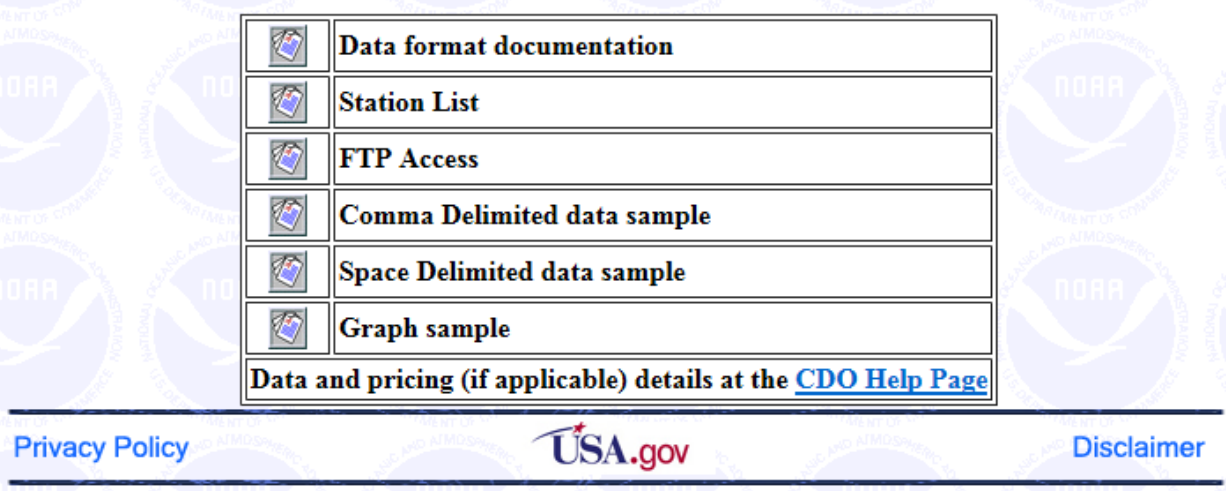

http://www7.ncdc.noaa.gov/CDO/cdoselect.cmd

Downloaded Tue Jul 05 16:00:09 EDT 2016

Production Version

If you have questions or comments, please contact our support team.

\subsection{Projected installation monthly average temperature data}

In order to analyze the impact of climate change on installation energy consumption, we also need projected installation monthly average temperature data in addition to historic monthly average temperature data. Using the output of a number of the most credible general circulation models (GCMs), it is possible to develop projections of monthly average temperatures at almost any location of interest. Initially, ERDC developed projected daily maximum and minimum surface temperatures $\left[{ }^{\circ} \mathrm{C}\right]$ and projected daily precipitation levels [mm/day] for all U.S.-based Army installations over the timeframe from 1 Jan 2006 to 31 Dec 2100 using the Community Climate System Model (CCSM4). CCSM4 is a coupled climate 
model for simulating the earth's climate system. It is a subset of the Community Earth System Model (CESM), which is a fully-coupled, global climate model that provides state-of-the-art computer simulations of the Earth's past, present, and future climate states.

CESM is sponsored by the National Science Foundation (NSF) and the U.S. Department of Energy (DOE). Administration of the CESM is maintained by the Climate and Global Dynamics Laboratory (CGD) at the National Center for Atmospheric Research (NCAR).

Composed of four separate models simultaneously simulating the earth's atmosphere, ocean, land surface and sea-ice, and one central coupler component, CCSM4 allows researchers to conduct fundamental research into the earth's past, present, and future climate states. The website for this information is: http://www.cesm.ucar.edu/models/ccsm4.0/ (accessed 2 Sep 2015).

Figure 16 and Figure 17 are samples of CCSM4 output for thirteen installations. Figure 16 contains projected daily maximum temperature values $\left[{ }^{\circ} \mathrm{C}\right]$ and Figure 17 contains projected daily minimum temperature values $\left[{ }^{\circ} \mathrm{C}\right]$.

Figure 16. Projected daily maximum temperatures $\left[{ }^{\circ} \mathrm{C}\right]$ for thirteen selected installations.

\begin{tabular}{|l|l|l|l|l|l|l|c|}
\hline \hline \multicolumn{1}{|c|}{ A } & \multicolumn{1}{|c|}{ B } & \multicolumn{1}{c|}{ C } & \multicolumn{1}{c|}{ D } & \multicolumn{1}{c|}{ E } & F & G \\
\hline 1 & Inst & GCM & RCP & Run & Date & Variable & Value \\
\hline 2 & Fort Benning & CCSM4 & rcp85 & r1i1p1 & $1 / 1 / 2006$ tasmax & 17.34685 \\
\hline 3 & Fort Bliss & CCSM4 & rcp85 & r1i1p1 & $1 / 1 / 2006$ tasmax & 14.76857 \\
\hline 4 & Fort Bragg & CCSM4 & rcp85 & r1i1p1 & $1 / 1 / 2006$ tasmax & 12.80169 \\
\hline 5 & Fort Campbell & CCSM4 & rcp85 & r1i1p1 & $1 / 1 / 2006$ tasmax & 12.19507 \\
\hline 6 & Fort Carson & CCSM4 & rcp85 & r1i1p1 & $1 / 1 / 2006$ tasmax & 7.945263 \\
\hline 7 & Fort Drum & CCSM4 & rcp85 & r1i1p1 & $1 / 1 / 2006$ tasmax & -3.75409 \\
\hline 8 & Fort Hood & CCSM4 & rcp85 & r1i1p1 & $1 / 1 / 2006$ tasmax & 15.58089 \\
\hline 9 & Fort Huachuca & CCSM4 & rcp85 & r1i1p1 & $1 / 1 / 2006$ tasmax & 14.63181 \\
\hline 10 & Fort Leonard Wood & CCSM4 & rcp85 & r1i1p1 & $1 / 1 / 2006$ tasmax & 13.89912 \\
\hline 11 & Fort Polk & CCSM4 & rcp85 & r1i1p1 & $1 / 1 / 2006$ tasmax & 18.72955 \\
\hline 12 & Fort Riley & CCSM4 & rcp85 & r1i1p1 & $1 / 1 / 2006$ tasmax & 13.74879 \\
\hline 13 & Fort Sill & CCSM4 & rcp85 & r1i1p1 & $1 / 1 / 2006$ tasmax & 13.96454 \\
\hline 14 & Fort Stewart & CCSM4 & rcp85 & r1i1p1 & $1 / 1 / 2006$ tasmax & 19.32904 \\
\hline
\end{tabular}


Figure 17 . Projected daily minimum temperatures $\left[{ }^{\circ} \mathrm{C}\right]$ for thirteen selected installations.

\begin{tabular}{|c|c|c|c|c|c|c|c|}
\hline 4 & A & B & C & D & $\mathrm{E}$ & $F$ & G \\
\hline 1 & Inst & GCM & $\mathrm{RCP}$ & Run & Date & Variable & Value \\
\hline 2 & Fort Benning & CCSM4 & rсp85 & r1i1p1 & $1 / 1 / 2006$ & tasmin & 8.281661 \\
\hline 3 & Fort Bliss & CCSM4 & rcp85 & r1i1p1 & $1 / 1 / 2006$ & tasmin & 5.028099 \\
\hline 4 & Fort Bragg & CCSM4 & rcp85 & r1i1p1 & $1 / 1 / 2006$ & tasmin & 2.290742 \\
\hline 5 & Fort Campbell & CCSM4 & rcp85 & r1i1p1 & $1 / 1 / 2006$ & tasmin & 1.056911 \\
\hline 6 & Fort Carson & CCSM4 & rcp85 & r1i1p1 & $1 / 1 / 2006$ & tasmin & -3.97001 \\
\hline 7 & Fort Drum & CCSM4 & rcp85 & r1i1p1 & $1 / 1 / 2006$ & tasmin & -19.7179 \\
\hline 8 & Fort Hood & CCSM4 & rcp85 & r1i1p1 & $1 / 1 / 2006$ & tasmin & 10.40528 \\
\hline 9 & Fort Huachuca & CCSM4 & rcp85 & r1i1p1 & $1 / 1 / 2006$ & tasmin & 1.410311 \\
\hline 10 & Fort Leonard Wood & CCSM4 & rcp85 & r1i1p1 & $1 / 1 / 2006$ & tasmin & -0.68499 \\
\hline 11 & Fort Polk & CCSM4 & rcp85 & r1i1p1 & $1 / 1 / 2006$ & tasmin & 8.54957 \\
\hline 12 & Fort Riley & CCSM4 & rсp85 & r1i1p1 & $1 / 1 / 2006$ & tasmin & 1.886091 \\
\hline 13 & Fort Sill & cCSM4 & rcp85 & r1i1p1 & $1 / 1 / 2006$ & tasmin & 4.827988 \\
\hline 14 & Fort Stewart & CCSM4 & rсp85 & r1i1p1 & $1 / 1 / 2006$ & tasmin & 8.750248 \\
\hline
\end{tabular}

The model runs (shown in Figure 16 and Figure 17) were conducted at Representative Concentration Pathway (RCP) 8.5. RCPs are four greenhouse gas-concentration trajectories adopted by the Intergovernmental Panel on Climate Change (IPCC) for its fifth Assessment Report (IPCC 2012). RCPs are used for climate modeling and research. They are descriptions of four future climate scenarios, all of which are considered possible depending on the magnitude of greenhouse gas emissions and aerosol concentrations in future years. The four RCPs (RCP 2.6, RCP 4.5, RCP 6.0 and $\mathrm{RCP} 8.5)$ are named after a possible range $(+2.6,+4.5,+6.0$, and +8.5 $\mathrm{W} / \mathrm{m}^{2}$, respectively) of radiative forcing values in the year 2100 relative to preindustrial values (IPCC 2017). A plot of these trajectories is shown in Figure 18. 
Figure 18 All forcing agents' atmospheric $\mathrm{CO}_{2}$-equivalent concentrations (in parts-per-million-by-volume (ppmv)) according to four RCPs.

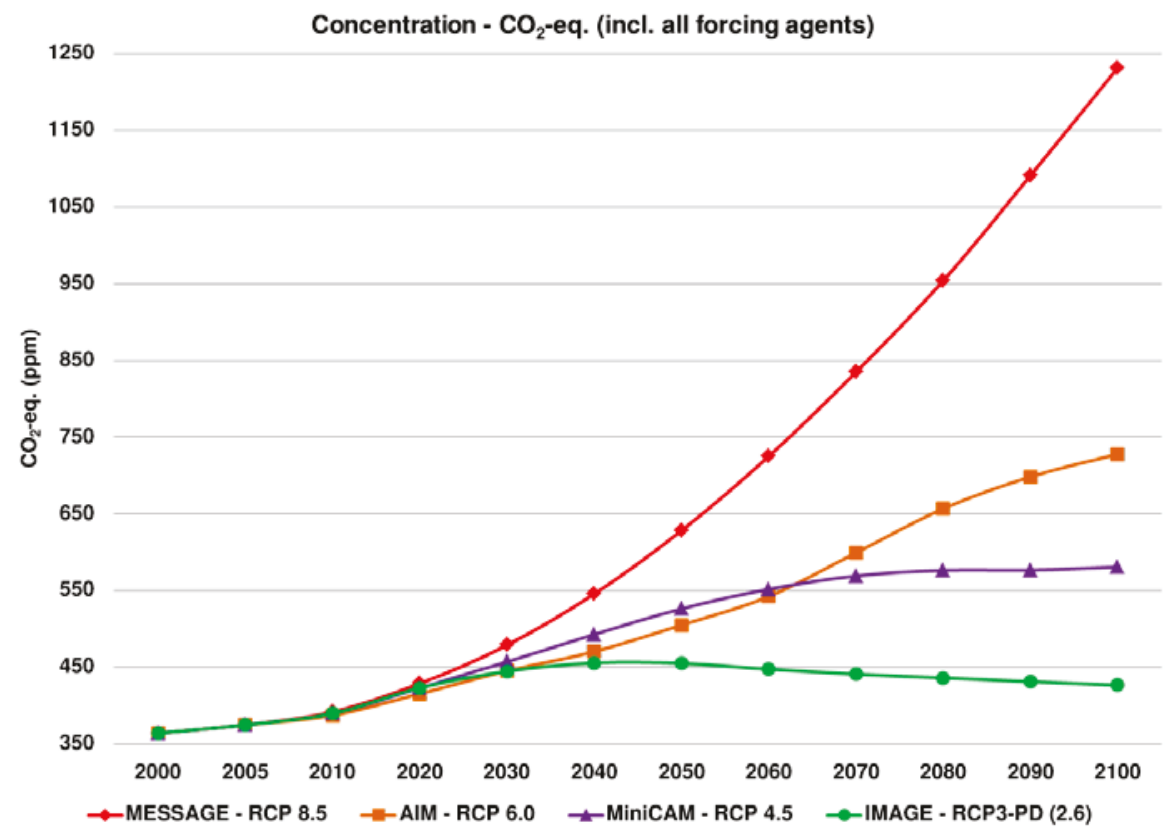

We developed a capability to perform the same analysis using nine other GCM models at up to four RCPs each. The models used and their respective RCPs are shown in Table 6. The resulting output data are archived in Microsoft Excel .csv files and easily manipulated to provide projected maximum and minimum temperatures for any day(s) of interest and for any of the selected installations. Monthly average temperatures can be easily derived by averaging the daily average temperatures for each day of the months of interest.

Table 6. GCM models and RCPs used to project monthly average temperature data.

\begin{tabular}{|l|l|l|l|l|}
\hline Model & RCP 2.6 & RCP 4.5 & RCP 6.0 & RCP 8.5 \\
\hline BCC-CSM1-1 & $\mathrm{x}$ & $\mathrm{x}$ & $\mathrm{x}$ & $\mathrm{x}$ \\
\hline CANESM2 & $\mathrm{x}$ & $\mathrm{x}$ & - & $\mathrm{x}$ \\
\hline CCSM4 & $\mathrm{x}$ & $\mathrm{x}$ & $\mathrm{x}$ & $\mathrm{x}$ \\
\hline CNRM-CM5 & - & $\mathrm{x}$ & - & $\mathrm{x}$ \\
\hline CSIRO-MK3-6-0 & $\mathrm{x}$ & $\mathrm{x}$ & - & $\mathrm{x}$ \\
\hline GFDL-CM3 & $\mathrm{x}$ & - & $\mathrm{x}$ & $\mathrm{x}$ \\
\hline ISPL-CM5A-LR & $\mathrm{x}$ & $\mathrm{x}$ & $\mathrm{x}$ & $\mathrm{x}$ \\
\hline MIROC5 & $\mathrm{x}$ & $\mathrm{x}$ & $\mathrm{x}$ & $\mathrm{x}$ \\
\hline MPI-ESM-LR & $\mathrm{x}$ & $\mathrm{x}$ & - & $\mathrm{x}$ \\
\hline NORESM1-M & $\mathrm{x}$ & $\mathrm{x}$ & $\mathrm{x}$ & $\mathrm{x}$ \\
\hline
\end{tabular}


For purposes of this project we only analyzed the CCSM4 model at RCP 8.5 and the CANESM2 at RCP 2.6 because the current immature state of our prototype software algorithms made it very difficult and time consuming to perform these analyses on a large scale. The CCSM4 model at RCP 8.5 is considered to be one of the more conservative GCM-RCP combinations, tending to project the greatest effect (i.e., worst case scenario) of climate change. The CANESM2 at RCP 2.6 is expected to project a lesser effect of climate change. Using just these two models, we analyzed the five subject installations and developed projected annual EUI (MMBTU/kSF/year) time series from 2020 to 2050. The resulting time series for a generic installation using just these two GCM-RCP combination models is presented in Appendix D in the tabular format shown in the example below (Table 7).

Table 7. Current form of projected annual EUI time series tabular output.

\begin{tabular}{|l|l|l|l|l|l|l|l|}
\hline Installation X & $\mathbf{2 0 2 0}$ & $\mathbf{2 0 2 5}$ & $\mathbf{2 0 3 0}$ & $\mathbf{2 0 3 5}$ & $\mathbf{2 0 4 0}$ & $\mathbf{2 0 4 5}$ & $\mathbf{2 0 5 0}$ \\
\hline Max EUI & 60.0 & 60.6 & 61.2 & 61.8 & 62.4 & 63.1 & 63.7 \\
\hline Mean EUI & 54.0 & 54.5 & 55.0 & 55.4 & 55.9 & 56.4 & 56.9 \\
\hline Min EUI & 48.0 & 48.4 & 48.7 & 49.0 & 49.3 & 49.7 & 50.0 \\
\hline
\end{tabular}

FY17 follow-on work by the ERDC Information Technology Laboratory (ERDC-ITL) has further developed previous prototype software algorithms to enable large-scale analysis of a time series of EUI projections out to 2100 (results in preparation at time this report was published). The algorithms apply to many installations using all combinations of GCM models and RCPs listed above in Table 6. It is expected that annual EUI data will be available from approximately $34 \mathrm{GCM} / \mathrm{RCP}$ combinations and that the output format will be changed to provide a 95\% confidence interval within 2 standard deviations, similar to that shown in Table 8.

Table 8. Updated form of projected annual EUI time series tabular output.

\begin{tabular}{|l|l|l|l|l|l|l|l|}
\hline Installation X & $\mathbf{2 0 2 0}$ & $\mathbf{2 0 2 5}$ & $\mathbf{2 0 3 0}$ & $\mathbf{2 0 3 5}$ & $\mathbf{2 0 4 0}$ & $\mathbf{2 0 4 5}$ & $\mathbf{2 0 5 0}$ \\
\hline EUI (Upper Bound) & 60.0 & 60.6 & 61.2 & 61.8 & 62.4 & 63.1 & 63.7 \\
\hline Mean EUI & 54.0 & 54.5 & 55.0 & 55.4 & 55.9 & 56.4 & 56.9 \\
\hline EUI (Lower Bound) & 48.0 & 48.4 & 48.7 & 49.0 & 49.3 & 49.7 & 50.0 \\
\hline
\end{tabular}




\subsection{Historic installation population data}

It is certain that changes in population will impact installation energy consumption. To investigate this correlation, historical installation population data are needed.

For management purposes, the Army collects and compiles historic and projected installation population data in the Army Stationing and Installation Plan (ASIP) database. ASIP contains past quarterly population data for every year from 2007 for each installation. Authorized users have access to read-only ASIP data and reports. Data can be shown for a specific location, Army command, year, unit, or query.

Figure 19 is an image of the ASIP database search screen showing quarteryear population data from Fort Carson. The data can be exported to Excel for further analysis, as shown in Figure 20.

Figure 19. Image of ASIP database search screen showing population data from Fort Carson for FY2007 to FY2013.

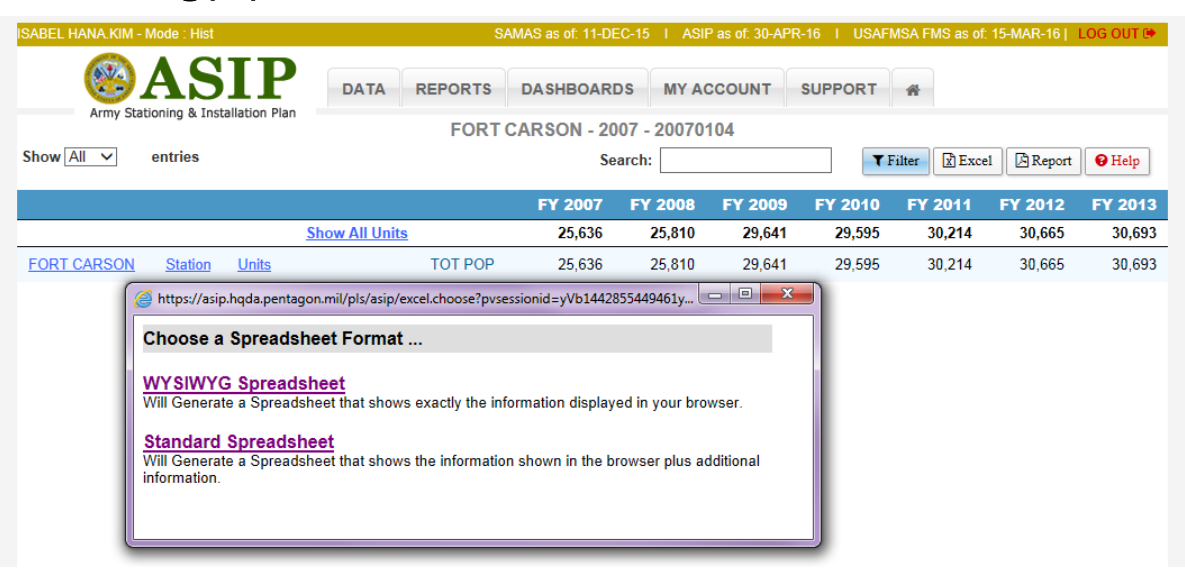


Figure 20. Image of an exported ASIP population file for Fort Carson.

\begin{tabular}{|c|c|c|c|c|c|c|c|c|c|c|c|c|c|c|c|c|c|c|}
\hline 2 & A & B & C & D & E & G & $\mathrm{H}$ & I & J & $\mathrm{k}$ & L & M & $\mathrm{N}$ & 0 & $\mathrm{P}$ & Q & $\mathrm{R}$ & $\mathrm{s}$ \\
\hline 1 & \multicolumn{18}{|c|}{ Histocial ASIP } \\
\hline 2 & \multicolumn{18}{|c|}{ No Current Filters } \\
\hline 3 & \multicolumn{18}{|c|}{ Units in Base FORT CARSON as of 20070104} \\
\hline 4 & UICCC & STACO & СOMPO & TYPCO & CARSS & UNMBR & UNTDS & UNDES & ASGMT & & FY 2007 & FY 2008 & FY 2009 & FY 2010 & FY 2011 & FY 2012 & FY 2013 & \\
\hline 5 & G19208 & 0813Q- (U & 1) 2 & & 1 & OMP & DET MP & NTERNMEN & NNG & TOT POP: & : $\quad 0$ & 0 & 24 & 24 & 24 & 24 & 24 & \\
\hline 6 & WA2UC1 & 08135- (FC & 1 & & 2 & $20 \mathrm{FA}$ & BNFAB & BTRYC1P & PFC & TOT POP: & 5 & 5 & 5 & 5 & 5 & 5 & 5 & \\
\hline 7 & WAC9AA & 08135- (FC & 1 & & 3 & $16 \mathrm{FA}$ & BN FIEL & ARTILLERY I & IFC & TOT POP: & 353 & 353 & 353 & 353 & 353 & 353 & 353 & \\
\hline 8 & WAJ2AA & 08135- (FC & 1 & & 1 & $4 \mathrm{EN}$ & HQENG & NEER BATTA & $\triangle F C$ & TOT POP: & 173 & 175 & 175 & 175 & 175 & 175 & 175 & \\
\hline 9 & WAJ5AA & 08135- (FC & 1 & & 3 & $4 \mathrm{AR}$ & HHC HE, & DQUARTERS & $S F C$ & TOT POP: & 157 & 157 & 157 & 157 & 157 & 157 & 157 & \\
\hline 10 & WAJEAA & 08135- (FC & 1 & & 1 & 704 CS & BN BRIC & ADE SUPPOF & FFC & TOT POP: & 872 & 872 & 872 & 872 & 901 & 901 & 901 & \\
\hline 11 & WAJFAA & 08135- (FC & 1 & & 2 & $2 \mathrm{IN}$ & HHC HE, & DQUARTERS & $S F C$ & TOT POP: & 153 & 153 & 153 & 153 & 153 & 153 & 153 & \\
\hline 12 & WAJJAA & 08135- (FC & 1 & & 2 & $12 \mathrm{IN}$ & BN INFA & NTRY BATTA & $A F C$ & TOT POP: & 684 & 684 & 684 & 684 & 684 & 684 & 684 & \\
\hline 13 & WAJPAA & 08135- (FC & 1 & & 1 & 9 IN & BN INFA & NTRY BATTA & $\triangle F C$ & TOT POP: & 684 & 682 & 682 & 682 & 682 & 682 & 682 & \\
\hline 14 & WAKBAA & 08135- (FC & 1 & & 1 & $8 \mathrm{IN}$ & BN MAI & EUVER BATT & TFC & TOT POP: & 700 & 700 & 700 & 700 & 700 & 700 & 700 & \\
\hline 15 & WAKPAA & 08135- (FC & 1 & & 1 & $68 \mathrm{IN}$ & BN MAI & EUVER BAT & TFC & TOT POP: & 700 & 700 & 700 & 700 & 700 & 700 & 700 & \\
\hline 16 & WALBAA & 08135- (FC & 1 & & 1 & 9 IN & BN INF & $\mathrm{N}(\mathrm{BFV})$ & FC & TOT POP: & 684 & 684 & 684 & 684 & 684 & 684 & 684 & \\
\hline 17 & WALWAA & $08135-$ (FC & 1 & & 4 & $42 \mathrm{FA}$ & BN FIEL & ARTILLERY & IFC & TOT POP: & 0 & 0 & 353 & 353 & 353 & 353 & 353 & \\
\hline 18 & WAN4AA & $08135-$ (FC & 1 & & 1 & $22 \mathrm{IN}$ & BN MAI & EUVER BAT & TFC & TOT POP: & 0 & 0 & 700 & 700 & 700 & 700 & 700 & \\
\hline 19 & WANGAA & $08135-$ (FC & 1 & & 1 & $4 \mathrm{AR}$ & $\mathrm{HHCHO}$ & , UNIT OF EI & $\mathrm{EFC}$ & TOT POP: & 332 & 332 & 332 & 332 & 332 & 332 & 332 & \\
\hline 20 & IWANLAA & $08135-$ (FC & 1 & & 1 & 4 AR & HHC HE & DQUARTERS & $S F C$ & TOT POP: & 0 & 0 & 157 & 157 & 157 & 157 & 157 & \\
\hline 21 & WANL!A & 08135- (FC & 1 & & 1 & 4 AR & HHC HE, & CFORWARL & LFC & TOT POP: & 78 & 78 & 0 & 0 & 0 & 0 & 0 & \\
\hline 22 & WANMAA & A 08135- (FC & 1 & 1 & 2 & 4 AR & $\mathrm{HHCHE}$ & DQUARTERS & SFC & TOT POP: & 157 & 157 & 157 & 157 & 157 & 157 & 157 & \\
\hline 23 & WANQA1 & 08135- (FC & 1 & 1 & 1 & $4 \mathrm{CS}$ & HHC SUS & T. DMMC TM & VFC & TOT POP: & 14 & 14 & 14 & 14 & 14 & 14 & 14 & \\
\hline 24 & WANZAA & $08135-$ (FC & 1 & 1 & 1 & $10 \mathrm{AR}$ & SQARM & DRED RECON & $\mathrm{NFC}$ & TOT POP: & 377 & 377 & 377 & 377 & 377 & 377 & 377 & \\
\hline 25 & WAQ2AA & 08135- (FC & 1 & 1 & 1 & 67 IN & BN MAI & EUVER BATT & TFC & TOT POP: & 702 & 702 & 702 & 702 & 702 & 702 & 702 & \\
\hline 26 & WAS7AA & 08135- (FC & 1 & 1 & 1 & $62 \mathrm{EN}$ & COSAP & ER COMPAN & & TOT POP: & 104 & 104 & 104 & 104 & 104 & 104 & 104 & \\
\hline 27 & WASHAA & 08135- (FC & 1 & 1 & 1 & $66 \mathrm{IN}$ & BN MAN & EUVER BATT & & TOT POP: & 0 & 0 & 700 & 700 & 700 & 700 & 700 & \\
\hline 28 & WASUAA & 08135- (FC & 1 & 1 & 2 & $8 \mathrm{IN}$ & BN MAI & EUVER BATT & & TOT POP: & 700 & 700 & 700 & 700 & 700 & 700 & 700 & \\
\hline n & IMAAVEA A & no13e $t \mathrm{cr}$ & 1 & 1 & , & $0 \wedge D$ & COADMA & hecnderans & & Th t מחת. & 277 & 277 & 277 & 277 & 277 & 277 & 277 & \\
\hline
\end{tabular}

After reviewing the available ASIP data, we concluded that the non-granular nature of this population data would not contribute to the analysis, so we did not incorporate installation population data into the energy analysis. 


\section{Analytical Results}

\subsection{Selection of demonstration installations}

This chapter addresses the analysis process used to project the future energy impact of climate change on installations. To develop an analysis process, the five installations indicated by yellow stars in Figure 21 (Fort Bliss, TX; Fort Bragg, NC; Fort Carson, CO; Fort Riley, KS; and Fort Sill, OK) were selected. These sites were chosen for comparison purposes because they are located in differing ASHRAE/IECC Climate Zones. The zones are defined as follows:

- Climate Zone 3A (warm-humid, $4500<\mathrm{CDD} 50^{\circ} \mathrm{F} \leq 6300$ ) - Fort Bragg and Fort Sill

- Climate Zone 3B (warm-dry, $4500<\mathrm{CDD} 50^{\circ} \mathrm{F} \leq 6300$ ) - Fort Bliss

- Climate Zone 4A (mixed-humid, $\mathrm{CDD} 50^{\circ} \mathrm{F} \leq 4500$ AND $3600<$ HDD $\left.65^{\circ} \mathrm{F} \leq 5400\right)-$ Fort Riley

- Climate Zone 5B (cool-dry, $5400<\mathrm{HDD}_{5} 5^{\circ} \mathrm{F} \leq 7200$ ) - Fort Carson

Figure 21. ASHRAE/IECC climate zones map showing approximate locations of Fort Bliss, Fort Bragg, Fort Carson, Fort Riley, and Fort Sill.

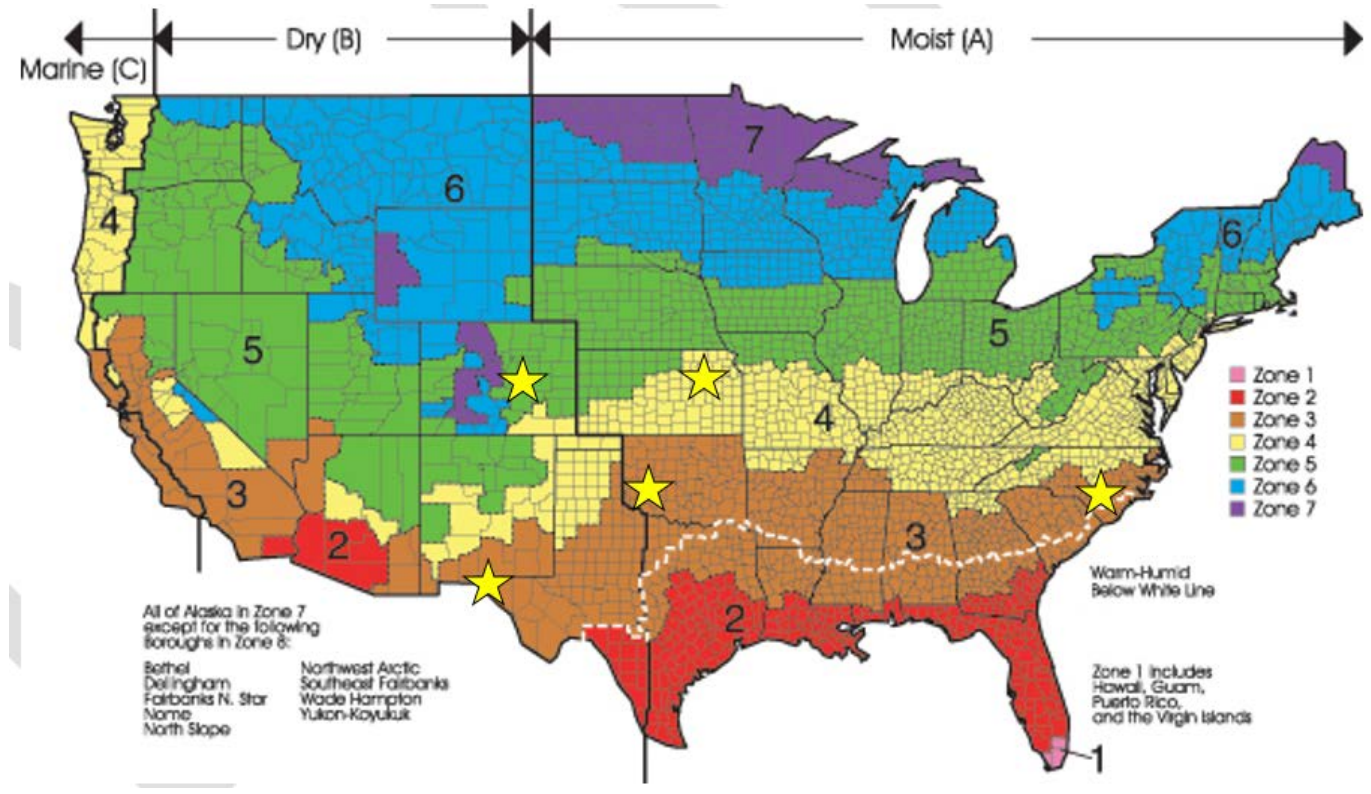

In the Climate Zone descriptions above, humid (moist) and dry are defined as follows:

- Moist (A) definition - Locations that are not marine and not dry. 
- Dry (B) definition - Locations meeting the following criteria:

- Not marine and

○ $\quad P<0.44 \times(T-19.5)$ [I-P units]

where:

$$
P=\text { annual precipitation in inches and }
$$

$T=$ annual mean temperature in ${ }^{\circ} \mathrm{F}$

- Marine (C) definition - Locations meeting all four of the following criteria:

- Mean temperature of coldest month between $27^{\circ} \mathrm{F}$ and $65{ }^{\circ} \mathrm{F}$

○ Warmest month mean $<72{ }^{\circ} \mathrm{F}$

- At least four months with mean temperatures over $50^{\circ} \mathrm{F}$

- Dry season in summer. The month with the heaviest precipitation in the cold season has at least three times as much precipitation as the month with the least precipitation in the rest of the year. The cold season is October through March in the Northern Hemisphere and April through September in the Southern Hemisphere (ASHRAE 2007).

Data required for this analysis process includes the following:

- Historic installation energy data (AEWRS)

- Historic installation facility square footage data (AEWRS)

- Historic installation mean monthly temperature data (NOAA GSOD data, see Appendix C for access instructions) https://data.noaa.gov/dataset/global-surface-summary-of-the-day-gsod

- Projected installation mean monthly temperature data (climate projections from multiple GCM models)

\subsection{Building area comparison}

Numerous factors other than climate can impact installation energy consumption, including mission changes, operational tempo, and the size and state of repair of conditioned building area. In order to perform a fair comparison between the five selected installations, we first considered the amount of conditioned building area, with focus on changes in the amount of conditioned building area.

As shown in Figure 22, the conditioned space at the five installations shown was quite stable after 2QFYo6 and up until 4QFYo8. The conditioned building area at Fort Sill has been relatively unchanged since 2006 but there has been a significant increase in the conditioned space at Fort 
Bliss and Fort Bragg up until 1QFY16. Presumably, newly constructed buildings at these and other installations would be more energy efficient than the older building stock there, so one would expect the installation EUI, measured in MMBTU/kSF/year, would be lowered over time due to newly constructed facilities.

Figure 22. Changes in conditioned building area at Fort Bliss, Fort Bragg, Fort Carson, Fort Riley, and Fort Sill.

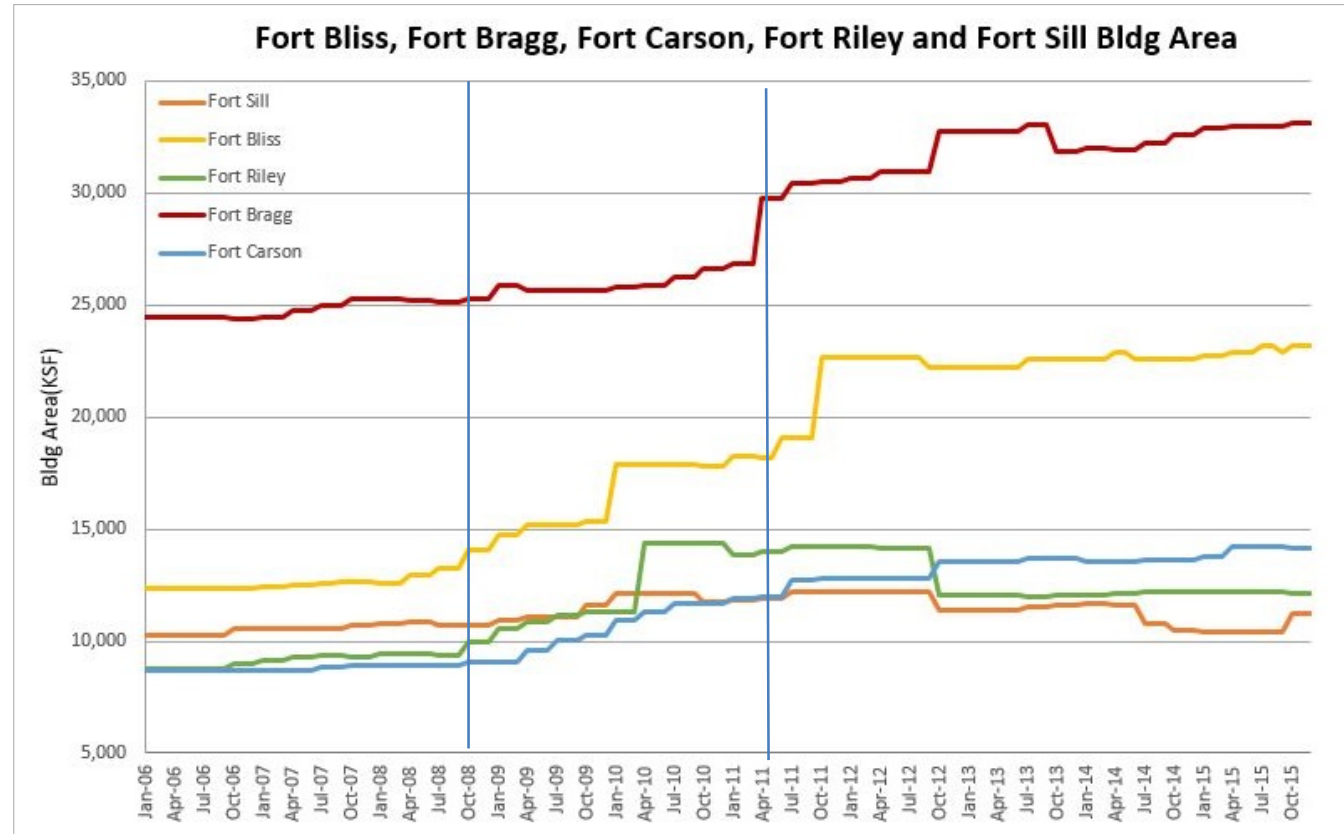

\subsection{Installation EUI analysis}

The primary objective of this work was to analyze historic monthly installation energy consumption data in conjunction with historic building area data to develop monthly installation EUIs for the total of all purchased energy sources, then compare these monthly EUIs to coincident historic monthly average temperature data to develop characteristic monthly EUI curves for the sum of all purchased energy sources at each installation. These characteristic EUI curves could then be used with projected monthly average temperature data to develop projected monthly EUIs for total purchased energy.

Using Fort Bliss as an example, Figure 23 through Figure 25 illustrate that Fort Bliss uses the most energy (in MMBTU) during cooler parts of the year. However, the installation's energy costs are greatest during the warmest parts of the year, largely due to the fact that electrical energy 
tends to cost approximately three times as much as natural gas energy on a dollars per MMBTU basis. This trend is typical of most installations.

Figure 23. Fort Bliss monthly average temperature, December 2013 to March 2015.

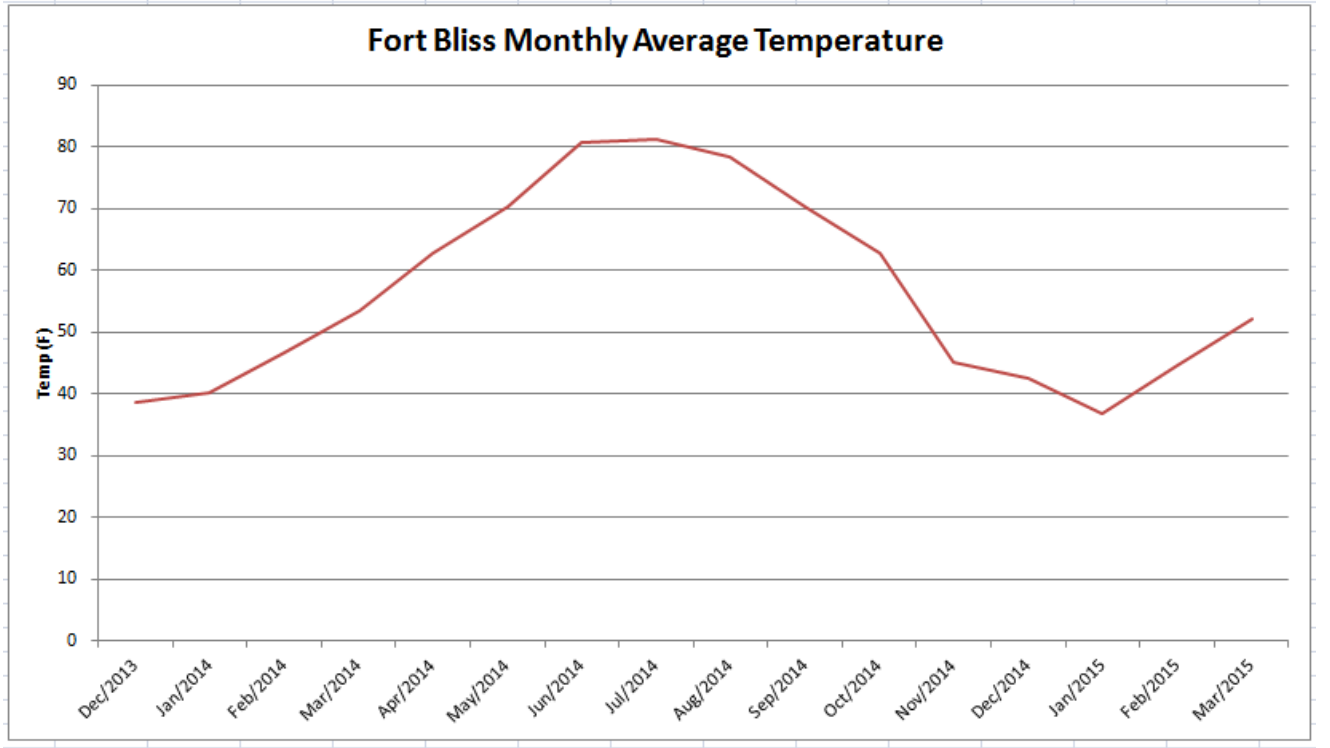

Figure 24. Fort Bliss total monthly energy consumption, December 2013 to March 2015.

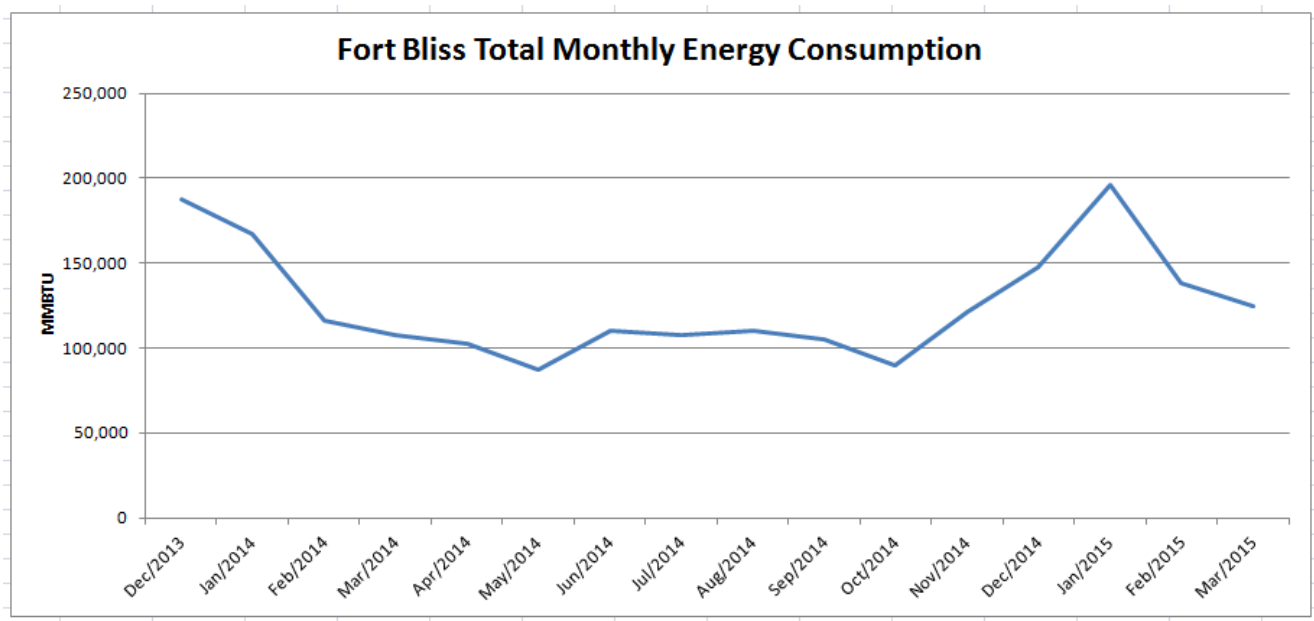


Figure 25. Fort Bliss monthly energy cost, December 2013 to March 2015.

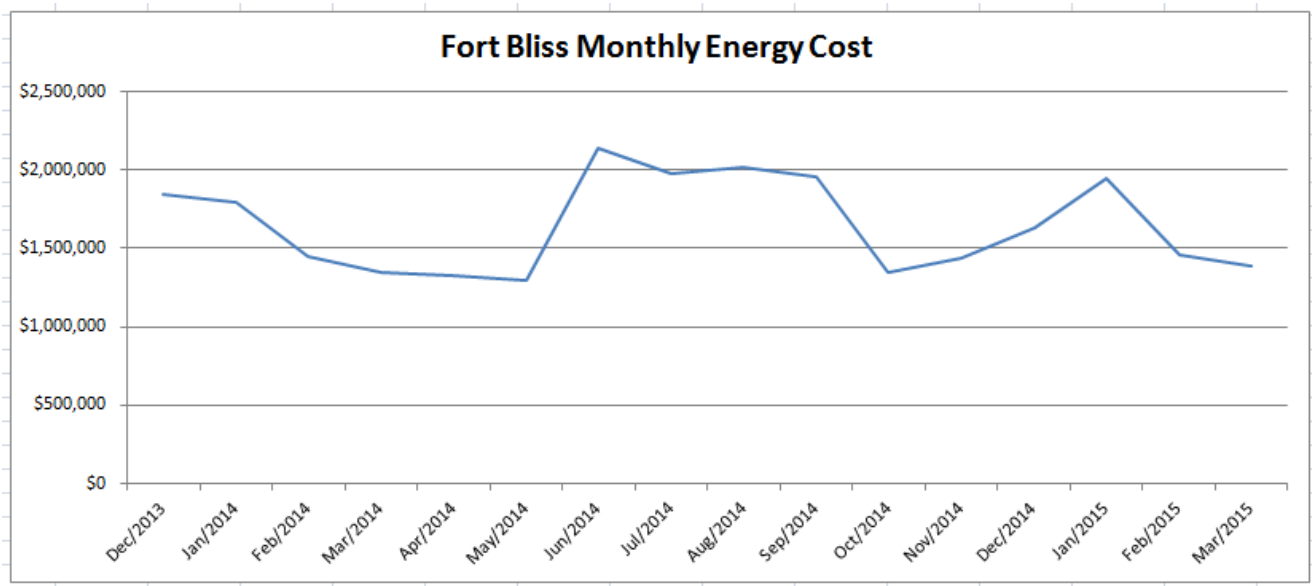

In Figure 26, the monthly EUI for Fort Bliss for electrical energy (ELC), gas energy (NAG), propane energy (PPG) and the sum (total energy) of electrical energy and gas energy is plotted against monthly average temperature for the 10-year period from January 2006 to December 2015. In this case, we plotted energy consumption data for propane (PPG) but did not include it in our plot of total energy because it was relatively insignificant compared to the sum of electrical energy and gas energy. Curve fits were developed for monthly EUI for natural gas, electricity, and the sum of natural gas and electricity as a function of monthly average temperature. Note that the curve fits for total energy and gas energy are much better than for electrical energy which probably can be attributed to the fact that electrical energy is used for many more non-temperature dependent applications than natural gas. As a result, the relationship between monthly average temperature and consumption of electrical energy is not as strong as it is for natural gas. It is also noted that the residuals $\left(\mathrm{R}^{2}\right)$ for the curve fits for electricity, natural gas, and total energy are quite low, ranging from 0.2 to 0.64 . 
Figure 26. Plot of Fort Bliss Monthly EUI

vs monthly average temperature for Jan 2006 to Dec 2015.

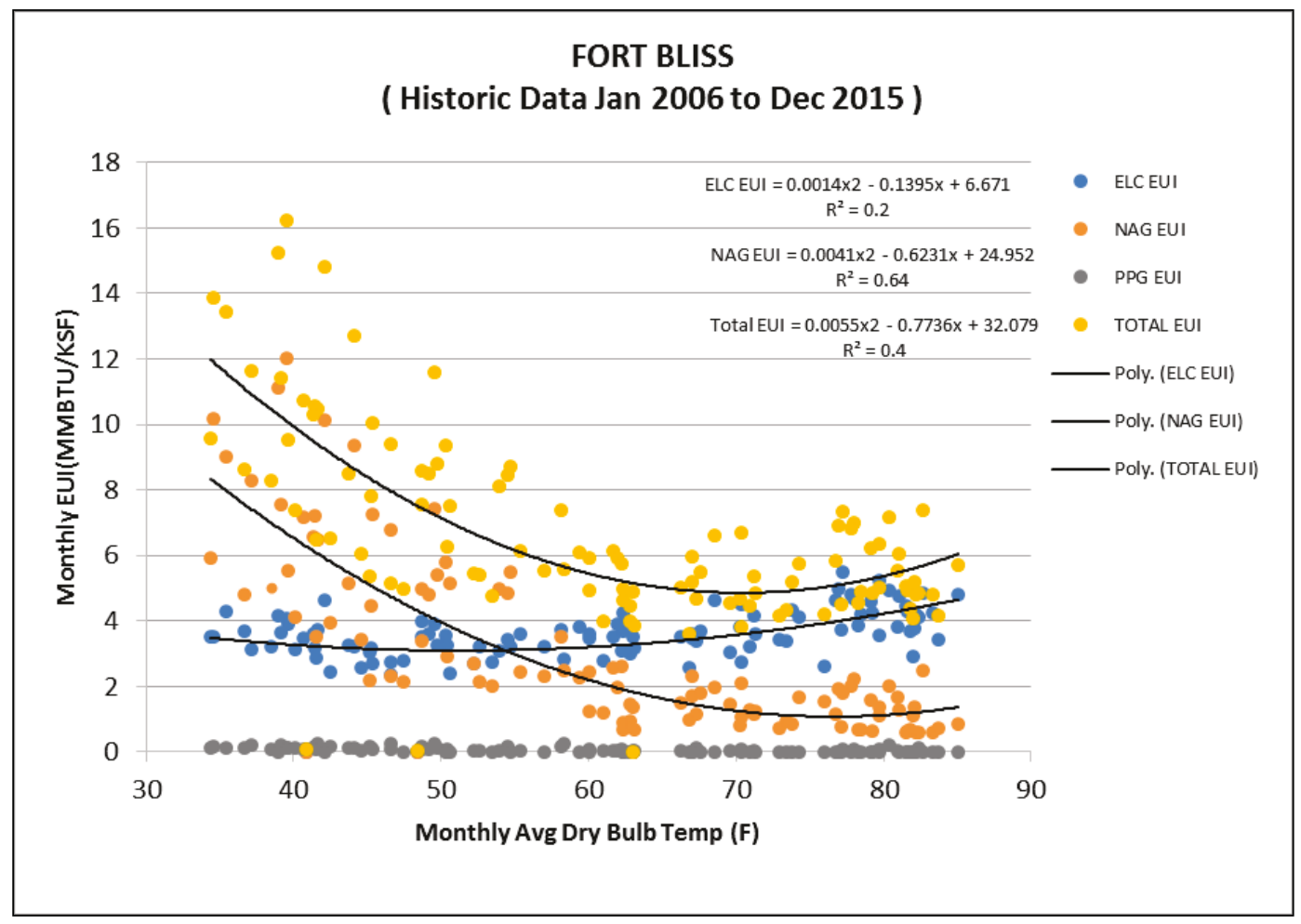

We found that much better residuals (closer to 1) resulted when we shortened the period being evaluated. For example, in Figure 27, for the period from December 2013 to March 2015, the residuals for natural gas and total energy were 0.93 and 0.94 , respectively, and 0.77 for electricity. 
Figure 27. Plot of Fort Bliss monthly EUI

vs historic monthly average temperature for the period Dec 2013 to Mar 2015.

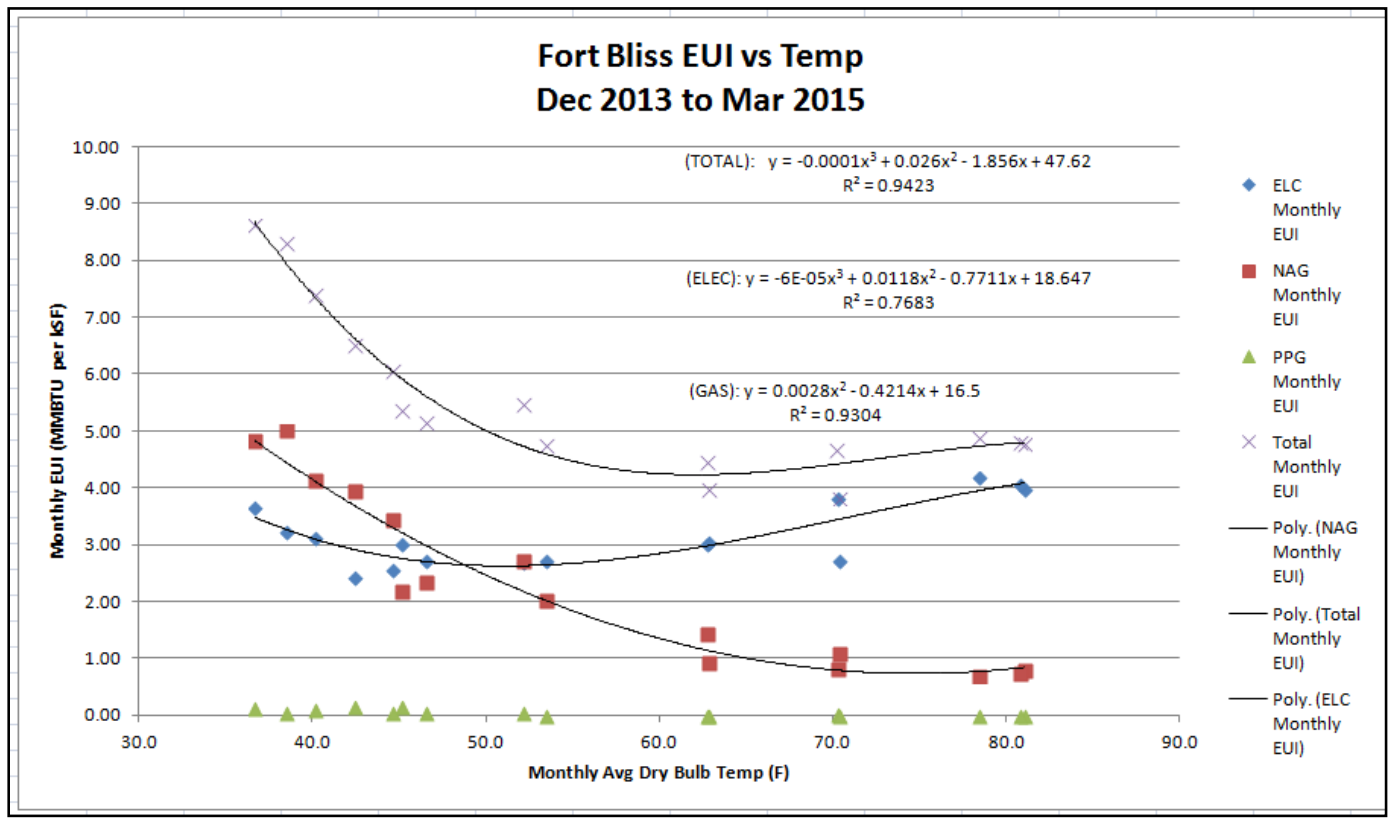

The improved residuals may be explained by the fact that it appears the installations are, in fact, becoming more energy efficient over time, probably in response to energy-efficiency investments, replacement of older, inefficient buildings with newer, more-efficient buildings, and other factors such as possible growth in renewable energy capacity over time. As a result, there is a significant difference in the EUI plotted data from one twoyear increment to another two-year increment (Figure 28). This makes it difficult or impossible to generate a good curve fit (with a high residual) to represent data plotted over extended periods of time. 
Figure 28. Fort Bliss EUI data plotted in two-year increments.

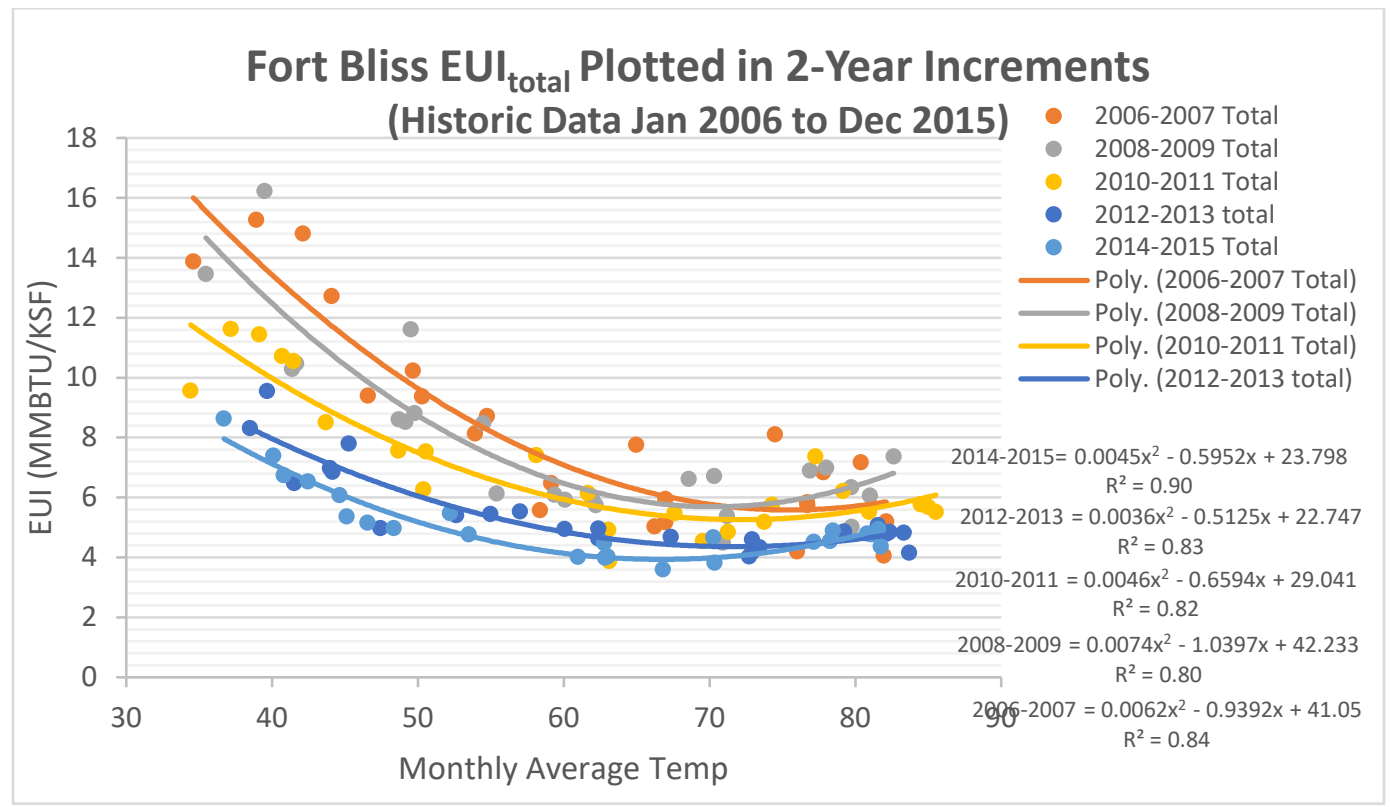

The general assumption is that climate change will result in increased temperatures. This may be true at many and perhaps most locations. Figure 29 portrays projections of monthly average temperatures at Fort Bliss in 10-year increments based on the CCSM4 general circulation model at an RCP of 8.5. According to this model, Fort Bliss can be expected to see a trend of warming monthly average temperatures over the next four decades. Other GCM models at other RCPs can be expected to produce somewhat different results.

Figure 29. Projected monthly average temperatures for Fort Bliss based on the CCSM4 GCM at an RCP of 8.5.

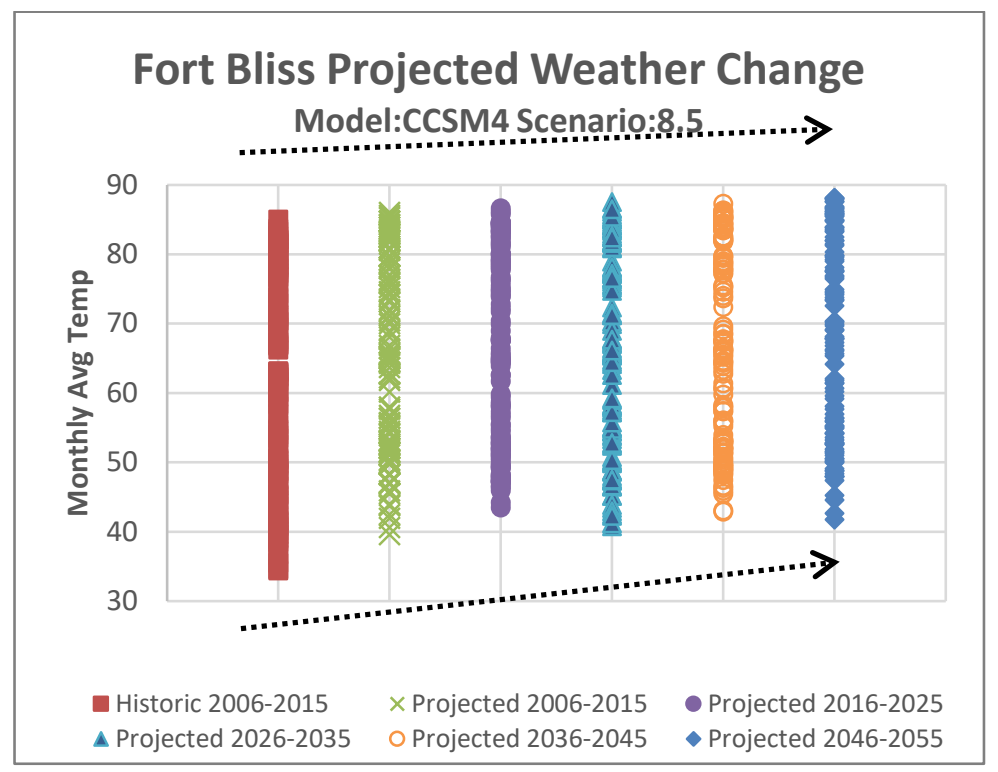


Figure 30 shows characteristic monthly EUI curves for electricity, natural gas and propane at a hypothetical installation. Assuming that future climates would be characterized by warmer temperatures, then at least some of the projected monthly average temperatures in future years would be expected to be skewed toward the right-hand side of a present day characteristic curve for the installation. In order to project the monthly EUIs for electricity, natural gas, and other energy sources, it would be necessary to extrapolate the curve fits that were developed based on historical average temperatures and corresponding monthly EUI data to find projected monthly EUIs based on projected monthly average temperatures.

Figure 30. Projected monthly EUI vs projected monthly average temperatures.

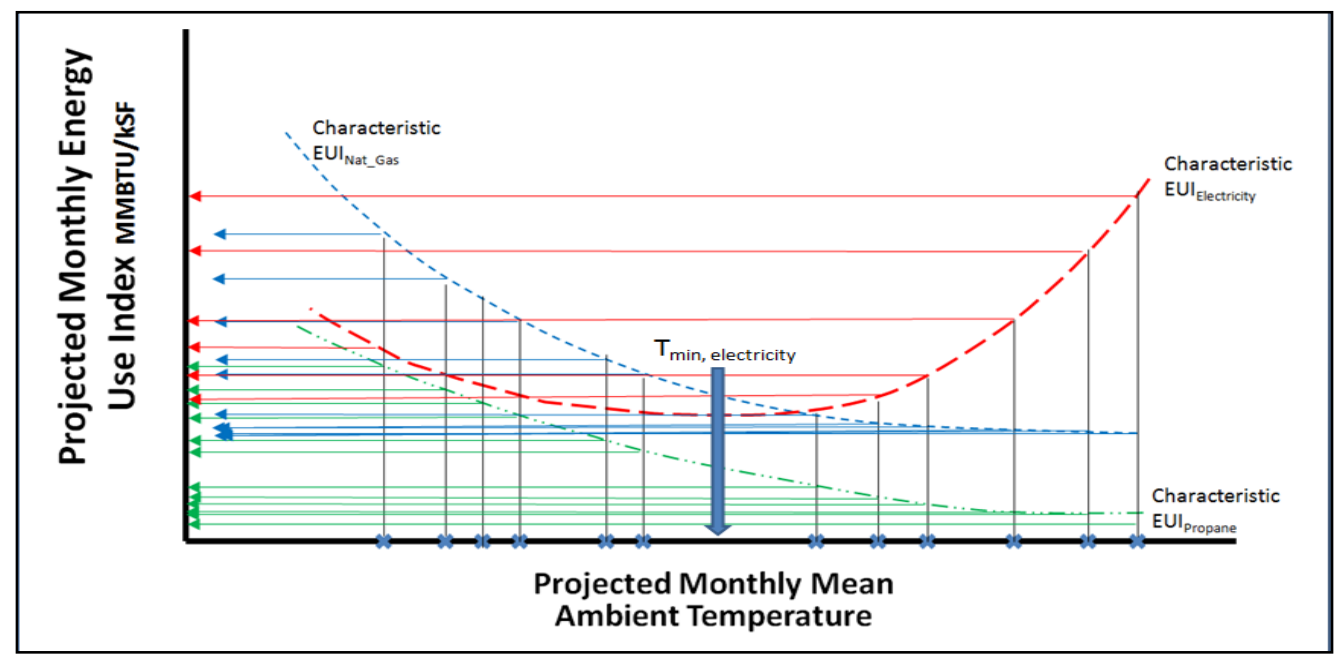

Extrapolation beyond existing data can be risky, but it does not seem to be a particularly big problem to extrapolate monthly EUIs for natural gas, propane, and other heating energy sources because they appear to gradually and predictably diminish with increasing monthly average temperatures. Extrapolation does appear to be a problem for projecting monthly electrical EUIs because it seems more difficult to achieve a good curve fit for electrical EUIs. A possible approach to improve monthly EUI curve fits for electricity might be to develop two curve fits for the electricity EUI on either side of $\mathrm{T}_{\mathrm{min}}$, electricity, as shown in Figure 30.

Ultimately, we decided to forego generating individual monthly EUI curve fits for each possible energy source. Instead, we achieved good results by generating a monthly EUI curve fit for total purchased energy using two years of historic energy consumption data in conjunction with corresponding historic installation square footage data and corresponding historic monthly average temperature data. 


\subsection{Projecting climate change impacts on future energy consumption}

Ultimately, we need to know how installations might be compared in terms of how their energy consumption and energy costs might be impacted by climate change. One way to achieve this would be to compare the change in their mean annual EUI (MMBTU/kSF/year) at future time intervals. Table 9 and Figure 31 depict projected mean annual EUIs for the five subject installations.

Table 9. Projected mean annual EUI (MMBTU/kSF/year) for Five Installations from 2020 to 2050.

\begin{tabular}{|c|c|c|c|c|c|c|c|}
\hline $\begin{array}{l}\text { Mean } \\
\text { Annual } \\
\text { EUl }\end{array}$ & $\begin{array}{l}2020 \\
(2018- \\
2022)\end{array}$ & $\begin{array}{l}2025 \\
(2023- \\
2027)\end{array}$ & $\begin{array}{l}2030 \\
(2028- \\
2032)\end{array}$ & $\begin{array}{l}2035 \\
(2033- \\
2037)\end{array}$ & $\begin{array}{l}2040 \\
(2038- \\
2042)\end{array}$ & $\begin{array}{l}2045 \\
(2043- \\
2047)\end{array}$ & $\begin{array}{l}2050 \\
(2048- \\
2052)\end{array}$ \\
\hline Fort Bliss & 60.2 & 59.6 & 60.2 & 60.5 & 60.6 & 60.5 & 60.1 \\
\hline Fort Bragg & 99.1 & 99.4 & 98.9 & 100.2 & 98.4 & 99.1 & 99.0 \\
\hline Fort Carson & 92.0 & 93.5 & 90.5 & 92.1 & 91.4 & 91.2 & 87.3 \\
\hline Fort Riley & 93.8 & 94.7 & 93.3 & 95.0 & 92.4 & 94.0 & 92.1 \\
\hline Fort Sill & 101.6 & 101.9 & 101.3 & 102.9 & 101.6 & 101.9 & 100.7 \\
\hline
\end{tabular}

Figure 31. Graph of projected mean annual EUI (MMBTU/kSF/year) for Five Installations from 2020 to 2050.

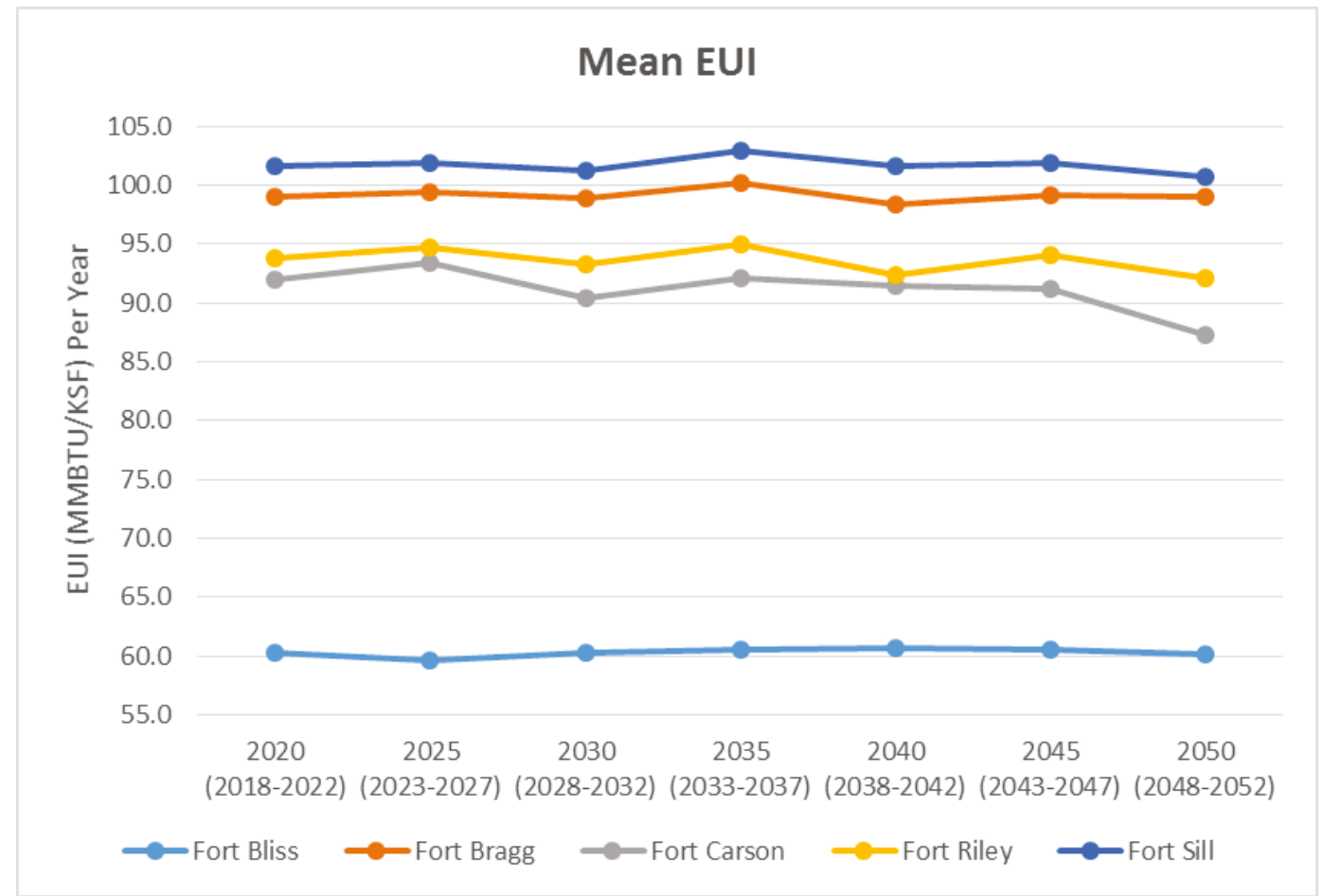


Note that data for both Table 9 and Figure 31 were generated using only two GCM/RCP combinations (CCSM4/RCP 8.5 and CANESM2/RCP 2.6). Presumably, these two combinations were expected to generate a large projected temperature response (CCSM4/RCP 8.5) and a small projected temperature response (CANESM2/RCP 2.6) to climate change. Assuming this to be true, these two combinations would set upper and lower bounds for the effects of climate change on future temperatures and show the greatest and least impacts on projected installation energy. Thus, one could depict projected impacts of climate change on installation energy by tabulating the upper and lower bounds and mean of Annual EUIs for installations at selected intervals as shown in Table 10.

Table 10. Portrayal of projected annual EUI for Fort Bliss at 5-year intervals.

\begin{tabular}{|c|c|c|c|c|c|c|c|}
\hline Fort Bliss & $\begin{array}{l}2020 \\
(2018- \\
2022)\end{array}$ & $\begin{array}{l}2025 \\
(2023- \\
2027)\end{array}$ & $\begin{array}{l}2030 \\
(2028- \\
2032)\end{array}$ & $\begin{array}{l}2035 \\
(2033- \\
2037)\end{array}$ & $\begin{array}{l}2040 \\
(2038- \\
2042)\end{array}$ & $\begin{array}{l}2045 \\
(2043- \\
2047)\end{array}$ & $\begin{array}{l}2050 \\
(2048- \\
2052)\end{array}$ \\
\hline Annual EUI (Upper Bound) & 60.5 & 60.2 & 60.2 & 61.2 & 61.4 & 61.0 & 60.4 \\
\hline MEAN Annual EUI & 60.2 & 59.6 & 60.2 & 60.5 & 60.6 & 60.5 & 60.1 \\
\hline Annual EUI (Lower Bound) & 60.0 & 59.2 & 60.2 & 59.8 & 59.8 & 60.0 & 59.8 \\
\hline
\end{tabular}

As noted, the results shown in Table 10 were based on the results of only two GCM/RCP combinations because the algorithms we were not fully automated, making it difficult to analyze a large number of GCM/RCP combinations. (The results of follow-on work to automate these algorithms, making it possible to perform this analysis for a large number of GCM/RCP combinations for many installations, is expected to be published by ERDC-ITL during 2018.) 


\section{Conclusions and Recommendations}

\subsection{Conclusions}

The purpose of the methodology developed in this multiyear project was to take an energy-data snapshot of each installation at a point in time so the dependent variable (projected installation energy consumption) would respond to a single independent variable (projected monthly average temperatures). The result of the work was that the research team developed a relatively simple methodology for projecting how climate change will affect installation energy consumption and energy costs. The methodology incorporates a number of significant simplifying assumptions in order to compare installations in terms of climate-change impacts without knowing how any of them may expand or contract, add or subtract mission, improve energy efficiency, etc.

For most of FY15 the work was encumbered due to lack of access to projected weather data (Swearingen et al. 2016). However, the issue was resolved with the availability of projected daily maximum and minimum temperature data from a broad range of GCM models and RCPs for any selected U.S. location of interest. These data became available in FY16 and will be used in all future analyses.

This work required accessing and analyzing many large digital files, especially files containing weather-data projections. Without having an automated means of retrieving and analyzing these data, the work accomplished in FY16 was very cumbersome and the output results for five selected installations was limited to an analysis of only two GCM/RCP combinations. An ERDC follow-on effort to develop software to automate and integrate these data, currently in progress, will make the developed method much more time-efficient.

Our effort to project potential climate-change impacts on the use of renewable energy on Army installations provided inconclusive results. We found that renewable energy utilization would be driven primarily by factors other than climate change, such as DoD policy and energy-market dynamics. However, with federal statutes, executive orders, and DoD/Army goals and policies steadily promoting wider use of renewable and clean energy sources, it seems evident that climate change impacts on renewable energy 
utilization potential should be examined using other methods. Climate scientists are uncertain how climate change will affect cloud cover and wind. Warmer temperatures would modestly reduce efficiency of photovoltaic systems. However, it appears that the falling costs of renewable energy systems will virtually guarantee that they will be implemented more widely as time passes.

\subsection{Recommendations}

Refinement of the approach developed in this work to address more complexities and desirable refinements would potentially be valuable depending on the needs of planners as time passes. There are several opportunities to further develop and improve this analytical method in the future.

The first would be to incorporate dew point temperature (DPT) for use in conjunction with dry bulb temperatures to determine relative humidity levels. Variations in outdoor relative humidity levels directly correlate to cooling energy requirements.

The second opportunity for further development would be to evaluate the standard deviation of weather data to analyze the amount of temperature fluctuation in the outdoor air. Relatively minimal fluctuations in daily average temperatures throughout a given month would be expected to impose a much different energy requirement than large fluctuations. Large variations in daily average temperatures would be expected to create significant additional demand for heating and cooling energy on any given day.

A study of installation plans to replace or improve existing buildings and a study of the penetration of air conditioning systems, especially in northerly locations, would provide useful information on how installation energy requirements might be expected to change in the future.

An analysis of installation energy requirements by building type (Category Code) could be very informative. Installations with a preponderance of certain Category Codes may be more affected than other installations in terms of climate-change impacts on energy use.

Some installations are changing their mix of energy sources over time. For example, in an effort to reduce source energy requirements, some installations are increasing consumption of natural gas on site to generate electricity with usable heat and cooling as byproducts. This approach reduces 
consumption of electricity produced at distant utility plants and changes the installation's overall energy consumption profile.

There is a need to evaluate and project the increased installation of renewable energy capacity as this will offset the impact of climate change on installation energy requirements.

Finally, it would be useful to project how climate change will impact energy unit costs. It is not clear that the effect on utility costs can be predicted based on our current knowledge. 


\section{References}

Ahl, Douglas, Lee DeBaillie, Scott Schuetter. 2012. Impact of Climate Variability on the Energy Use and Economics of NASA Facilities: NASA Research Opportunities in Space and Earth Sciences 2011. Madison, WI: Energy Center of Wisconsin. https://www.seventhwave.org/sites/default/files/271-1.pdf

ANSI/ASHRAE/IESNA. 2007. Standard 90.1-2007. Energy Standard for Buildings Except Low-Rise Residential Buildings. https://ashrae.iwrapper.com/ViewOnline/Standard_90.1-2007 (I-P)

Baker, Joseph W. 2014. "Eliminating hurricane-induced storm surge damage to electric utilities via in-place elevation of substation structures and equipment." In T\&D Conference and Exposition, 2014 IEEE PES, pp. 1-5. IEEE, 2014, DOI: 10.1109/TDC.2014.6863459. http://www.distransubstations.com/images/uploads/resources/eliminating_hurricaninduced_storm_surge_damage_to_electric_utilities_via_inplace_elevation_of_substation_structures_and_equipment.pdfl, from http://ieeexplore.ieee.org/xpl/articleDetails.jsp?arnumber $=6863459$

Barthelmie, R. J., and Sara C. Pryor. 2014. "The potential contribution of wind energy to climate change mitigation." Nature Climate Change 4: 684-688.

Bolinger, Mark, and Joachim Seel. 2016. "Utility-Scale Solar 2015 An Empirical Analysis of Project Cost, Performance, and Pricing Trends in the United States." LBNL1006037, August 2016. Berkeley, CA: Lawrence Berkeley National Laboratory, University of California.

Branum, Don. 28 June 2012. “Academy presses on in face of Waldo Canyon fire.” US Air Force Academy, CO: USAFA Office of Public Affairs. http://www.usafa.af.mil/News/ArticleDisplay/tabid/1487/Article/428535/academy-presseson-in-face-of-waldo-canyon-fire.aspx

Change Science Program (CCSP). 2007. Effects of Climate Change on Energy Production and Use in the United States: A Report by the U.S. Climate Change Science Program and the subcommittee on Global Change Research. Washington, DC: Department of Energy, Office of Biological \& Environmental Research.

Clement, Amy C., Robert Burgman, and Joel R. Norris. 2009. "Observational and model evidence for positive low-level cloud feedback." Science 325.5939: 460-464.

Diamond, Kimberly E. 2011. "Global Warming's Impact on Wind Speeds: Long-Term Risks for Wind Farms May Impact Guarantees and Wind Derivatives Tied to Wind Energy Production.” Salt Lake City. In 4oth Annual Conference on Environmental Law.

Energy Independence and Security Act of 2007 (EISA). Public Law No. 110-140, 121 STAT. 1492 (2007). Approved 19 December 2007, 110th Congress. https://www.gpo.gov/fdsys/pkg/PLAW-110publ140/html/PLAW-110publ140.htm

Energy Policy Act (EPAct) of 1992. H.R.776, 102nd Congress (1992). https://www.congress.gov/bill/102nd-congress/house-bill/776/text/enr 
Energy Policy Act (EPAct) of 2005, Public Law No. 109-58. Approved 8 August 2005. http://energy.gov/sites/prod/files/2013/10/f3/epact_2005.pdf

Executive Office of the President. June 2013. The President's Climate Action Plan. Washington, DC: The White House, Executive Office of the President. https://obamawhitehouse.archives.gov/sites/default/files/image/president27sclimateactionpl an.pdf

Executive Order 13423. Strengthening Federal Environmental, Energy, and Transportation Management. Washington, DC: The White House, Office of the Press Secretary. 24 January 2007.

Executive Order 13514. Federal Leadership in Environmental, Energy and Economic Performance. Washington, DC: The White House, Office of the Press Secretary. 5 October 2009.

Executive Order 13653. Preparing the United States for the impacts of climate change. Washington, DC: The White House, Office of the Press Secretary. 6 November 2013.

Executive Order 13693. Planning for Federal Sustainability in the Next Decade. Washington, DC: The White House, Office of the Press Secretary. 25 March 2015.

Fant, Charles, C. Adam Schlosser, and Kenneth Strzepek. 2016. "The impact of climate change on wind and solar resources in southern Africa." Applied Energy 161: $556-564$.

Federal Power Act of 1920, 16 USC $\S 791 a(1920)$. https://legcounsel.house.gov/Comps/Federal\%20Power\%20Act.pdf

Global Summary Of the Day (GSOD). National Climatic Data Center, U.S. Department of Commerce. Washington, DC: NOAA. http://www7.ncdc.noaa.gov/CDO/cdoselect.cmd?datasetabbv=GSOD\&resolution=40

Godfrey, Matthew C. and Pail Sadin. 2012. "A_History of the U.S. Army's Residential Communities Initiative, 1995-2010.” Prepared for the Office of the Assistant Secretary of the Army; Installations, Energy and Environment. Missoula, MT: Historical Research Associates, Inc.

Hawkins, Kari. May 2011. "Redstone Restored to Full Power.” Decatur, AL: The Redstone Rocket (Redstone Arsenal). http://www.theredstonerocket.com/article_822d6c64-1ed7550bbb37-463370666183.html

Hunt, Jared. 21 August 2012. "Derecho Damage Hammers Utilities.” Charleston, WV: Charleston Gazette. http://www.wvgazettemail.com/News/201208200208

Intergovernmental Panel on Climate Change (IPCC). 2012. "Renewable Energy Sources and Climate Change Mitigation: Special Report of the Intergovernmental Panel on Climate Change." Cambridge, United Kingdom and New York, NY: Cambridge University Press.

_ Data Distribution Center. 2017. "Scenario Process For AR5: Representative Concentration Pathways (RCPs).” http://sedac.ipccdata.org/ddc/ar5_scenario_process/RCPs.html, last modified 14 May 2018. 
Kimball, Robert E. "Fire Scorches 38,00o Acres.” Nogales International, 1 May 2002. http://www.nogalesinternational.com/news/fire-scorches-acres/article_87cb116a-3506-5df383ae-11bdedf460e7.html.

KRDO News Channel 13. 28 Aug 2012. "Crews Work on Power Lines Damaged After Fire." Colorado Springs, CO: Pikes Peak Television, Inc. http://www.krdo.com/news/Crews-Work-On-Power-Lines-Damaged-After-Fire/16401430, last modified 14 July 2016.

Miller, James P., Juliana Wilhoit, Kristina Tranel, and Laura Curvey. September 2015. Climate Change Impacts on Water and Energy for Army Installations. ERDC/CERL TR-15-24. Champaign, IL: U.S. Army Engineer Research and Development Center, Construction Engineering Research Laboratory (ERDCCERL).

Mussoline, Meghan. 14 July 2015. "What is a Derecho?" State College, PA: AccuWeather. http://www.accuweather.com/en/weather-news/what-is-a-derecho/28089245, accessed 9 June 2017.

National Oceanic and Atmospheric Administration (NOAA). 2013. Data catalog. Global Summary Of the Day (GSOD) webpage. https://data.noaa.gov/dataset/global-surfacesummary-of-the-day-gsod, accessed 16 August 2016.

—. 2017. "About Derechos." Norman, OK: NOAA National Weather Service, Storm Prediction Center. http://www.spc.noaa.gov/misc/AbtDerechos/derechofacts.htm, accessed 9 June 2017.

Pryor, S. C., and R. J. Barthelmie. 2011. "Assessing Climate Change Impacts on the NearTerm Stability of the Wind Energy Resource Over the United States." Proceedings of the National Academy of Sciences 108, No. 20 (2011): 8167-8171.

Rahim, Mustamin, Jun Yoshino, Yasuhiro Doi, and Takashi Yasuda. 2012. "Effects of Global Warming on the Average Wind Speed Field in Central Japan." Journal of Sustainable Energy \& Environment 3, no. 4, pp 165-171.

Ren, Diandong. 2010. "Effects of global warming on wind energy availability." Journal of Renewable and Sustainable Energy 2: 052301. doi: 10.1063/1.3486072.

Smith, Jennifer. 30 June 2014. Lessons from the Derecho. Charleston, WV: MetroNews Network. http://wvmetronews.com/2014/06/30/lessons-from-the-derecho/

Swearingen, Michelle E., Andrew Fulton, Wade Wall, Rachael Bakaitis, and John W. Weatherly. January 2016. Effects of Climate Change and Urban Development on Army Training Capabilities: Firing Ranges and Maneuver Areas. ERDC TR-16-1. Champaign, IL: U.S. Army Engineer Research and Development Center, Construction Engineering Research Laboratory (ERDC-CERL).

U.S. Department of Defense (DoD). 2012. DoD FY 2012 Climate Change Adaptation Roadmap. https://web.archive.org/web/20140707155818/http://www.acq.osd.milLie/download/green_energy/dod_sustainability/2012/Appendix\%20A\%20\%20DoD\%20Climate\%20Change\%20Adaption\%20Roadmap_20120918.pdf

U.S. Department of Defense (DoD). 2010. Strategic Sustainability Performance Plan. http://www.denix.osd.mil/sustainability/dod-sspp/unassigned/dod-sspp-fy-2010/ 
U.S. Department of Energy. October 2015. "Climate Change and the U.S. Energy Sector: Regional Vulnerabilities and Resilience Solutions." Washington, DC: Department of Energy, Office of Energy Policy and Systems Analysis.

https://energy.gov/epsa/downloads/climate-change-and-us-energy-sector-regionalvulnerabilities-and-resilience-solutions

U.S. Department of Energy. July 2013. "U.S. Energy Sector Vulnerabilities to Climate Change and Extreme Weather." DOE/PI-o013. Washington, DC: Department of Energy.

U.S. Department of Energy. August 2012. A Review of Power Outages and Restoration Following the June 2012 Derecho. Washington, DC: DOE, Office of Electricity Delivery and Energy Reliability.

http://www.oe.netl.doe.gov/docs/Derecho\%202012_\%20Review_080612.pdf

U.S. Department of Energy. August 2010. "High-Performance Home Technologies: Guide to Determining Climate Regions by County." Volume 7.1, Building America Best Practices Series. Prepared under Contract DE-ACo5-76LRO 1830, PNNL-17211. http://apps1.eere.energy.gov/buildings/publications/pdfs/building_america/ba_climateguide 7_1.pdf, accessed 1 Sep 2015.

U.S. Energy Information Administration (EIA). 11 September 2011. Texas Heatwave, August 2011: Nature and Effects of Electric Supply Shortage. Washington, DC: U.S. Energy Information Administration. https://www.eia.gov/todayinenergy/detail.cfm?id=3010

Weather Underground. 30 June 2012. WunderPhotos. Derecho Damage. Atlanta, GA: The Weather Channel Interactive. https://www.wunderground.com/wximage/apphotos/121

Wiser, Ryan, Karen Jenni, Joachim Seel, Erin Baker, Maureen Hand, Eric Lantz, and Aaron Smith. 2016."Forecasting wind energy costs and cost drivers." LBNL1005717. Berkeley, CA: Lawrence Berkeley National Laboratory, University of California. 


\section{Appendix A: Impact of Climate Change on Renewable Energy Potential}

Climate change has three main impacts on the potential for renewable energy: increased temperatures, changing wind and rain patterns, and changes in cloud cover. The increased temperatures decrease the output of photovoltaic (PV) systems, but increases in PV efficiency from technological advances should outpace the effects of increased temperatures. Predictions vary. The effects will likely vary by region. Many studies of climate change and the effects on renewable energy are therefore regional rather than global, focusing on specific geographical areas. Many also focus on recent changes in order to predict likely future changes. The following predictions of wind, solar, and hydroelectric energy generation in terms of the expected availability and technological changes come from a variety of sources which are documented as endnotes.

Wind

\section{Wind energy resource}

Researchers are currently divided as to whether climate change will increase or decrease wind speeds. A University of Texas-Austin researcher estimated that global temperature increases of $2{ }^{\circ} \mathrm{C}$ to $4{ }^{\circ} \mathrm{C}$ could result in a $4 \%$ to $12 \%$ decrease in average wind speeds in some northern latitudes. A DOE study concluded that it is not clear what the impact will be. An excerpt: "There is not yet substantial agreement among sources as to how a changing climate will ultimately affect wind resources in the United States in general, and in the Northwest in particular. One study of the Northwest region found significant seasonal declines in wind speed in parts of the Northwest, but this result has not been confirmed by additional studies. It is uncertain how wind power production may be disrupted by climate change-driven changes to wind patterns, or if wind power will see an increase in available capacity" (DOE, July 2013).

A 2009 Iowa State University study (Barthelmie 2014) found that average wind speeds across the country have already decreased .5\% to $1 \%$ since 1973. However, the cause for this is not clear. Three possibilities were brought about for the trend: changes in instrumentation produced flawed 
measurements; the study didn't account for land-use changes such as development and tree planting that slowed winds near instruments; or the climate is changing and one consequence is slower winds.

Researchers at the University of California-Santa Cruz found that climate change might cause coastal winds to increase.

A study by the University of Texas at Austin (Ren 2010) found that wind potential has decreased slightly in the United States over the last 40 years. The study theorizes that as temperatures continue to increase, wind power potential at the typical heights of wind turbines will decrease about $14 \%$ this century. This study was focused on China. The reason for this, the theory goes is that the driver of wind is the temperature difference from polar areas to the equator. Polar areas are increasing in temperature faster than tropical areas, hence a smaller temperature difference and resulting smaller driver of wind. This is expected to be more pronounced in northern latitudes.

A study published in Applied Energy (Fant 2016) predicts a median change close to zero by 2050 in the long-term mean of both wind speed and Global Horizontal Irradiance. However it also predicts the extreme possibilities range from $-15 \%$ to $+15 \%$, but at a low probability.

A study in Japan (Rahim 2012) found "Wind speed differs in each area depending on the land surface and topographical conditions, the highest annual wind speed is found in mountain and coastal areas. Increases and decreases of surface wind speeds in Central Japan are not found during 1961-2000, but the wind speeds are predicted to increase during 20012099. Changes of surface winds because of global warming will be at its greatest during 2001-2046."

Local winds could also slow down. However, in other areas, winds may actually increase, thanks to local temperature gradients becoming more influential than global ones. To add to the complexity, temperature gradients are not the only factors driving wind speeds. There are many other variables, including topography, land use, bodies of water, air moisture and land temperature. There are also many seasonal and daily variables.

Climate change could alter the jet stream, completely rearranging global air circulation and ocean currents, therefore changing many local wind 
patterns. There are also "interesting possibilities" of shifts in atmospheric circulation patterns such as El Nino/ La Nina Southern Oscillation (Diamond 2011).

Another concern is that increased severe wind incidents would increase the frequency and length of downtime of wind turbines due to increased wear and outright damage during severe events.

A 2008 report from the U.S. Climate Change Science Program (USCCSP) noted that wind power could see either "significant positive or negative effects" as a result of climate change. The bottom line is that nobody knows for certain what effect global warming will have on wind energy.

From a U.S. Department of Energy report (DOE, July 2013):

"Changes in diurnal and seasonal wind patterns could influence future wind power resource potential as significantly as changes in average annual wind speeds. Projections of wind patterns vary by region, emissions scenario, and climate model. As a result, there is not yet consensus as to how a changing climate will ultimately affect wind resources in the United States. From an energy generation perspective, changes to wind speed and direction are important at a range of temporal scales, from annual averages to changes in diurnal patterns. Average annual wind speeds in the United States could decrease by $1 \%-3 \%$ (Breslow and Sailor 2002) by mid-century, and by as much as $3 \%-14 \%$ at times in the Northwest according to a 2008 study (Sailor et al. 2008). However, a more recent evaluation of several regional climate models suggests that changes in U.S. wind resources through the middle of this century will not exceed changes associated with historic variability (Pryor and Barthelmie 2011).”

\section{Wind generation costs}

Experts anticipate cost reductions for wind generation capacity of $24 \%$ to $30 \%$ by 2030 and $35 \%$ to $41 \%$ by 2050 , under a median or "best guess" scenario, driven by bigger and more efficient turbines, lower capital and operating costs, and other advancements (Wiser et al. 2016). This is based on a 2014 baseline. 


\section{Solar}

\section{Solar energy resource}

An excerpt from Time magazine: But a new study published in the July 24 issue of Science is clearing the haze. A group of researchers from the University of Miami and the Scripps Institute of Oceanography studied cloud data of the northeast Pacific Ocean - both from satellites and from the human eye - over the past 50 years and combined that with climate models. They found that low-level clouds tend to dissipate as the ocean warms which means a warmer world could well have less cloud cover. "That would create positive feedback, a reinforcing cycle that continues to warm the climate," says Amy Clement, a climate scientist at the University of Miami and the lead author of the Science study (Clement, et al 2009).

From a U.S. Department of Energy report (DOE, July 2013):

"Increasing temperatures could reduce potential generation capacity of solar PV. Annual and seasonal photovoltaic (PV) output could be affected by increases in ambient air temperature; changes in cloud cover; and changes in haze, humidity, and dust (Omubo-Pepple et al. 2009, Chow et al. 2007). However, limited information has been published on the potential impacts of higher temperatures on solar resources in the United States.

Increasing temperatures decrease the efficiency of PV systems. The extent to which PV efficiencies are affected by temperature depends on the semiconducting material used. Crystalline silicon PV cells are more susceptible to heat-related efficiency losses (Omubo-Pepple et al. 2009, Chow et al. 2007) compared to newer technologies such as thin film PVs, which do not rely on crystalline silicon to produce electricity (Huld et al. 2010). The conversion efficiency of a crystalline silicon PV cell decreases by about $0.08 \%$ per $1.8^{\circ} \mathrm{F}\left(1^{\circ} \mathrm{C}\right)$ increase in air temperature when the ambient air temperature is above $77^{\circ} \mathrm{F}\left(25^{\circ} \mathrm{C}\right)$ (Radziemska 2003).

Studies of the potential change in irradiance are not consistent in either direction. Although the magnitude of the change could be as high as $15 \%$ or $20 \%$ at very high latitudes, the change would be smaller in most regions (Bartok 2010, Cutforth and Judiesch 2007, Pan et al. 2004). One study suggests that solar potential will generally decrease, with the most notable decreases being in the western United States in the fall, winter, 
and spring (Pan et al. 2004). In most of the United States, this study projects a trend toward decreased seasonal-mean daily global radiation in the range of o\% to 20\% by mid-century (Pan et al. 2004). One study in Europe estimated that a $2 \%$ decline in solar radiation paired with a $6.7^{\circ} \mathrm{F}$ $\left(3.7^{\circ} \mathrm{C}\right)$ increase in average ambient temperature could decrease solar panel power output by $6 \%$ (Fidje and Martinsen 2006). Understanding how cloud cover changes, including the types of clouds, will be important for understanding future solar resource potential. For example, increases in high thin cirrus clouds that are highly transparent to solar radiation will not have the same impact as lower clouds, such as stratocumulus clouds that are not as transparent and will result in less solar energy reaching the earth's surface (NASA 2013b).

\section{Solar energy generation costs}

Median installed PV project prices within a sizable sample have steadily fallen by nearly 60\% since the 2007-2009 period, to $\$ 2.7 / \mathrm{WAC}$ (or $\$ 2.1 / \mathrm{WDC}$ ) for projects completed in 2015. The lowest 2oth percentile of projects within our 2015 sample (of 64 PV projects totaling 2,135 MWAC) were priced at or below $\$ 2.2 / \mathrm{WAC}$, with the lowest-priced projects around \$1.7/WAC (Bolinger 2016).

\section{Hydroelectric}

\section{Hydroelectric energy resource}

Annual precipitation is generally expected to increase across the northern United States but decline in the southern states (NOAA, July 2013). Increasing temperatures could affect the operation of hydropower facilities and decrease available generation capacity in some regions. Increasing temperatures will increase evaporative water losses and consumptive water use in upstream watersheds, decreasing water availability for hydropower and the operational flexibility of hydropower projects (CCSP 2007).

\section{From a U.S. Department of Energy report (DOE, July 2013):}

Increasing temperatures could affect the operation of hydropower facilities and decrease available generation capacity in some regions. Increasing temperatures will increase evaporative water losses and consumptive water use in upstream watersheds, decreasing water availability for hydropower and the operational flexibility of hydropower projects (CCSP 
2007). Increasing air and water temperatures may intensify stratification of some reservoirs behind dams and deplete dissolved oxygen both in the reservoirs and downstream, which may degrade habitat for fish and other wildlife. Such water quality changes can affect growth, reproduction, migration, and survival of aquatic fauna and may cause changes in community structure and biodiversity (McCullough et al. 2009, Jager et al.

1999). This may impel regulatory limits on hydropower flow releases to mitigate adverse ecological effects of water quality fluctuations (Bevelhimer et al. 1997, FERC 1996). These limits can reduce the peak generation capacity of hydropower facilities and diminish the ability of hydropower facilities to respond quickly to electric system demands.

\section{Hydroelectric generation costs}

The installed cost of hydroelectric power varies widely, but generally is higher than most other renewable energy sources. Table B1 illustrates estimated costs.

Table B1. Installed hydroelectric power costs.

\begin{tabular}{|c|c|c|c|c|}
\hline & $\begin{array}{c}\text { Installed costs } \\
\text { (USDA/kW) }\end{array}$ & $\begin{array}{c}\text { Operations and } \\
\text { Maintenance costs } \\
\text { (\%/year of installed costs) }\end{array}$ & Capacity factor (\%) & $\begin{array}{c}\text { Levelized cost of } \\
\text { electricity } \\
\text { (2010 USDA/kWh) }\end{array}$ \\
\hline Large hydro & $1050-7650$ & $2-2.5$ & 25 to 90 & $0.02-0.19$ \\
\hline Small hydro & $1300-8000$ & $1-4$ & 20 to 95 & $0.02-0.27$ \\
\hline Refurbishment/upgrade & $500-1000$ & $1-6$ & & $0.01-0.05$ \\
\hline
\end{tabular}

\section{Summary}

Climate change will have impacts on the size and geographic distribution of the technical potential for renewable energy (RE) sources, but research into the magnitude of these possible effects is in the beginning stages. Because RE sources are, in many cases, dependent on the climate, global climate change will affect the RE resource base, though the precise nature and magnitude of these impacts is uncertain. The future technical potential for bioenergy could be influenced by climate change through impacts on biomass production such as altered soil conditions, precipitation, crop productivity and other factors. The overall impact of a global mean temperature change of less than $2{ }^{\circ} \mathrm{C}$ on the technical potential of bioenergy is expected to be relatively small on a global basis. However, considerable regional differences could be expected and uncertainties are larger and more difficult to assess compared to other RE options due to the large number 
of feedback mechanisms involved. For solar energy, though climate change is expected to influence the distribution and variability of cloud cover, most research indicates that the impact of these changes on overall technical potential will be small. For hydropower the overall impacts on the global technical potential is expected to be slightly positive. However, results also indicate the possibility of substantial variations across regions and even within countries. Research to date suggests that climate change is not expected to greatly impact the global technical potential for wind energy development but changes in the regional distribution of the wind energy resource may be expected. Climate change is not anticipated to have significant impacts on the size or geographic distribution of geothermal or ocean energy resources (IPCC 2012).

Changes in the economics of renewable energy generation capacity will most likely be much larger than the direct effects of climate change on renewable energy potential. The costs of renewable energy systems has been steadily decreasing. For instance, a study by Lawrence Berkeley National Laboratory (Bolinger 2016) found that installed costs of PV systems fell 5 to $12 \%$ in 2015 alone. Utility-scale solar project developers have been negotiating power sales agreements with utilities at prices averaging just $5 \mathrm{\phi} / \mathrm{kWh}$. Another study by Berkeley on the future costs of wind energy concluded "experts anticipate cost reductions of $24 \%$ to $30 \%$ by 2030 and $35 \%$ to $41 \%$ by 2050 , under a median or "best guess" scenario, driven by bigger and more efficient turbines, lower capital and operating costs, and other advancements" (Wiser et al. 2016).

As for the amount of renewable energy potential, the same report concluded "The theoretical potential of RE is much greater than all of the energy that is used by all the economies on Earth. The challenge is to capture it and utilize it to provide desired energy services in a cost-effective manner." (IPCC 2012). Figure B2 shows the estimated potential energy generation of various renewable resources. 
Figure B2. Potential renewable energy sources.

Note that "EJ" means "exajoules" (1 quintillion joules).

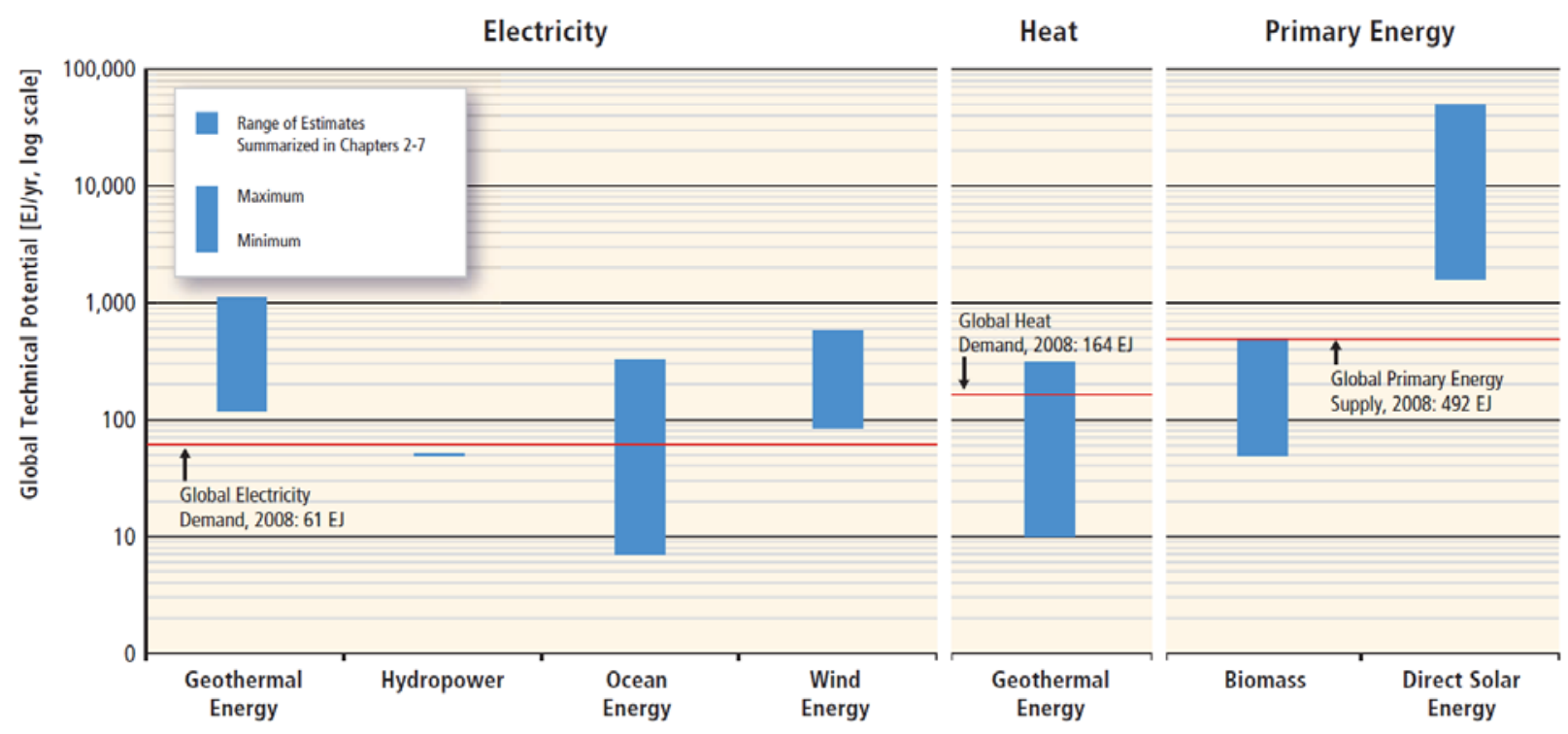




\section{Appendix B: AEWRS Installation List}

There are currently 144 Army installations in the AEWRS database. Not all installations in the AEWRS database are considered suitable for this analysis. For example, we do not currently have the means to project climate data for OCONUS installations. It is assumed that most National Guard organizations are variously located in their respective states. As a result, it would be impossible, at present, to break out the actual utilities data and square footage data at these varied locations for purposes of performing this analysis. Utility usage at industrial installations such as Army depots, ammunition plants, laboratories, and proving grounds are probably dominated by mission requirements, not building heating and cooling needs. Therefore, we considered them unsuitable for this analysis.

Installations considered suitable for analysis by the process outlined in this report are indicated in the "Suitable for Analysis" column in Table B1 below.

Table B1. Current List of installations in the AEWRS database.

\begin{tabular}{|c|c|c|c|c|c|c|c|c|}
\hline Installation & Location & $\begin{array}{l}\text { CONUS Re- } \\
\text { gion }\end{array}$ & $\begin{array}{l}\text { Suitable for } \\
\text { Analysis }\end{array}$ & $\begin{array}{l}\text { Com- } \\
\text { ment }\end{array}$ & Station Name & $\begin{array}{l}\text { ICAO } \\
\text { Codes }\end{array}$ & $\begin{array}{l}\text { WMO } \\
\text { Codes }\end{array}$ & $\begin{array}{l}\text { WBAN } \\
\text { Code }\end{array}$ \\
\hline 63RD RSC & $\mathrm{CA}$ & Southwest & No & Various & & & & \\
\hline 81ST RSC & SC & Southeast & No & Various & & & & \\
\hline 88TH RSC & WI & Midwest & No & Various & & & & \\
\hline 99TH RSC & $?$ & & No & Various & & & & \\
\hline 9TH MSC & $\mathrm{HI}$ & - & No & Various & & & & \\
\hline ABERDEEN PG & MD & Northeast & No & Industrial & & & & \\
\hline ADELPHI LABORATORY CTR & MD & Northeast & No & Lab & & & & \\
\hline ALABAMA ARNG & $\mathrm{AL}$ & Southeast & No & Various & & & & \\
\hline ALASKA ARNG & AK & - & No & Various & & & & \\
\hline ANNISTON ARMY DEPOT & AL & Southeast & No & Industrial & & & & \\
\hline ARIZONA ARNG & $A Z$ & Southwest & No & Various & & & & \\
\hline ARKANSAS ARNG & AR & Southeast & No & Various & & & & \\
\hline ARNGRC & VA & Southeast & Yes & & $\begin{array}{l}\text { Ronald Reagan } \\
\text { Washington Natl AP }\end{array}$ & $\mathrm{KDCA}$ & 72405 & \\
\hline BLUE GRASS ARMY DEPOT & KY & Southeast & No & Industrial & & & & \\
\hline CALIFORNIA ARNG & $\mathrm{CA}$ & Southwest & No & Various & & & & \\
\hline CAMP ZAMA JAPAN & Japan & & No & OCONUS & & & & \\
\hline CARLISLE BARRACKS & PA & Northeast & Yes & & $\begin{array}{l}\text { Harrisburg Interna- } \\
\text { tional Airport }\end{array}$ & KCXY & 72511 & \\
\hline COLORADO ARNG & $\mathrm{CO}$ & Southwest & No & Various & & & & \\
\hline
\end{tabular}




\begin{tabular}{|c|c|c|c|c|c|c|c|c|}
\hline Installation & Location & $\begin{array}{l}\text { CONUS Re- } \\
\text { gion }\end{array}$ & $\begin{array}{l}\text { Suitable for } \\
\text { Analysis }\end{array}$ & $\begin{array}{l}\text { Com- } \\
\text { ment }\end{array}$ & Station Name & $\begin{array}{l}\text { ICAO } \\
\text { Codes }\end{array}$ & $\begin{array}{l}\text { WMO } \\
\text { Codes }\end{array}$ & $\begin{array}{l}\text { WBAN } \\
\text { Code }\end{array}$ \\
\hline CONNECTICUT ARNG & CT & Northeast & No & Various & & & & \\
\hline CORPUS CHRISTI AD & $\mathrm{TX}$ & $\begin{array}{l}\text { S. Great } \\
\text { Plains }\end{array}$ & No & Industrial & & & & \\
\hline DC ARNG (MOB) & DC & Northeast & Yes & & $\begin{array}{l}\text { Ronald Reagan } \\
\text { Washington Natl AP }\end{array}$ & $\mathrm{KDCA}$ & 72405 & \\
\hline DELAWARE ARNG & $\mathrm{DE}$ & Northeast & No & Various & & & & \\
\hline DEVENS RFTA & MA & Northeast & Yes & & $\begin{array}{l}\text { Worchester Regional } \\
\text { Airport }\end{array}$ & $\mathrm{KORH}$ & 72510 & \\
\hline DUGWAY PROVING GROUND & UT & Southwest & No & Industrial & & & & \\
\hline FLORIDA ARNG & $\mathrm{FL}$ & Southeast & No & Various & & & & \\
\hline FORT A P HILL & VA & Southeast & Yes & & $\begin{array}{l}\text { Richmond Interna- } \\
\text { tional Airport }\end{array}$ & $\mathrm{KAPH}$ & & \\
\hline FORT BELVOIR & VA & Southeast & Yes & & Davison AAF Airport & KDAA & & 93728 \\
\hline FORT BENNING & $\mathrm{GA}$ & Southeast & Yes & & $\begin{array}{l}\text { Columbus Metropoli- } \\
\text { tan Airport }\end{array}$ & KLSF & 72225 & 13829 \\
\hline FORT BLISS & NM & $\begin{array}{l}\text { S. Great } \\
\text { Plains }\end{array}$ & Yes & & $\begin{array}{l}\text { Roswell Industrial Air } \\
\text { Center AP }\end{array}$ & $\mathrm{KBIF}$ & & 23009 \\
\hline FORT BRAGG & NC & Southeast & Yes & & $\begin{array}{l}\text { Raleigh Durham Inter- } \\
\text { national Airport }\end{array}$ & KFBG & 74693 & 93737 \\
\hline FORT BUCHANAN & $\begin{array}{l}\text { Puerto } \\
\text { Rico }\end{array}$ & & No & OCONUS & & & & \\
\hline FORT CAMPBELL & KY & Southeast & Yes & & Campbell AAF Airport & KHOP & 74671 & 13806 \\
\hline FORT CARSON & $\mathrm{CO}$ & Southwest & Yes & & $\begin{array}{l}\text { Denver International } \\
\text { Airport }\end{array}$ & KFCS & 72468 & 94015 \\
\hline FORT DETRICK & $\mathrm{MD}$ & Northeast & Yes & & $\begin{array}{l}\text { Frederick Municipal } \\
\text { Airport }\end{array}$ & KFDK & & 13730 \\
\hline FORT DRUM & NY & Northeast & Yes & & $\begin{array}{l}\text { Watertown in Interna- } \\
\text { tional Airport }\end{array}$ & KGTB & 74370 & 14715 \\
\hline FORT GEORGE MEADE & MD & Northeast & Yes & & Tipton Airport & KFME & & 93733 \\
\hline FORT GORDON & GA & Southeast & Yes & & $\begin{array}{l}\text { Augusta Regional at } \\
\text { Bush Field AP }\end{array}$ & KAGS & 72218 & 3820 \\
\hline FORT GREELY & AK & - & No & & & $\mathrm{PABI}$ & 70267 & 26415 \\
\hline FORT HAMILTON & NY & Northeast & Yes & & LA Guardia Airport & KLGA & 72503 & 14732 \\
\hline FORT HOOD & $\mathrm{TX}$ & $\begin{array}{l}\text { S. Great } \\
\text { Plains }\end{array}$ & Yes & & $\begin{array}{l}\text { Austin Bergstromn In- } \\
\text { ternational Airport }\end{array}$ & KGRK & & 3902 \\
\hline FORT HUACHUCA & $A Z$ & Southwest & Yes & & $\begin{array}{l}\text { Tucson International } \\
\text { Airport }\end{array}$ & KFHU & 72273 & 3124 \\
\hline FORT HUNTER LIGGETT & $\mathrm{CA}$ & Southwest & Yes & & $\begin{array}{l}\text { Salinus Municipal Air- } \\
\text { port }\end{array}$ & KKIC & & \\
\hline FORT IRWIN & $\mathrm{CA}$ & Southwest & Yes & & $\begin{array}{l}\text { San Bernardino Inter- } \\
\text { national Airport }\end{array}$ & KBYS & 74611 & 3182 \\
\hline FORT JACKSON & $\mathrm{SC}$ & Southeast & Yes & & $\begin{array}{l}\text { Columbia Metropoli- } \\
\tan \text { Airport }\end{array}$ & KCAE & 72310 & 13883 \\
\hline FORT KNOX & KY & Southeast & Yes & & $\begin{array}{l}\text { Lousiville International } \\
\text { Airport }\end{array}$ & KFTK & 72424 & 13807 \\
\hline FORT LEAVENWORTH & KS & $\begin{array}{l}\text { S. Great } \\
\text { Plains }\end{array}$ & Yes & & Forbes Field Airport & KFLV & 72441 & 13921 \\
\hline FORT LEE & VA & Southeast & Yes & & $\begin{array}{l}\text { Richmond Interna- } \\
\text { tional Airport }\end{array}$ & $\mathrm{KFCl}$ & & \\
\hline FORT LEONARD WOOD & MO & Midwest & Yes & & $\begin{array}{l}\text { Waynesville Regional } \\
\text { Airport at Forney Field }\end{array}$ & KTBN & 74550 & 3938 \\
\hline FORT MCCOY & WI & Midwest & Yes & & $\begin{array}{l}\text { La Crosse Municipal } \\
\text { Airport }\end{array}$ & KCMY & & 94940 \\
\hline FORT POLK & LA & Southeast & Yes & & $\begin{array}{l}\text { Lafayette Regional } \\
\text { Airport }\end{array}$ & KAEX & 74754 & 93915 \\
\hline FORT RILEY & KS & $\begin{array}{l}\text { S. Great } \\
\text { Plains }\end{array}$ & Yes & & $\begin{array}{l}\text { Salina Municipal Air- } \\
\text { port }\end{array}$ & KFRI & 72455 & 13947 \\
\hline FORT RUCKER & $A L$ & Southeast & Yes & & $\begin{array}{l}\text { Hanchey Army Heli- } \\
\text { port }\end{array}$ & KHEY & & 63873 \\
\hline
\end{tabular}




\begin{tabular}{|c|c|c|c|c|c|c|c|c|}
\hline Installation & Location & $\begin{array}{l}\text { CONUS Re- } \\
\text { gion }\end{array}$ & $\begin{array}{l}\text { Suitable for } \\
\text { Analysis }\end{array}$ & $\begin{array}{l}\text { Com- } \\
\text { ment }\end{array}$ & Station Name & $\begin{array}{l}\text { ICAO } \\
\text { Codes }\end{array}$ & $\begin{array}{l}\text { WMO } \\
\text { Codes }\end{array}$ & $\begin{array}{l}\text { WBAN } \\
\text { Code }\end{array}$ \\
\hline FORT SILL & OK & $\begin{array}{l}\text { S. Great } \\
\text { Plains }\end{array}$ & Yes & & Ardmore Municipal & KFSI & 72355 & 3950 \\
\hline FORT STEWART & GA & Southeast & Yes & & $\begin{array}{l}\text { Savannah Interna- } \\
\text { tional Airport }\end{array}$ & KLHW & 72209 & 3875 \\
\hline FORT WAINWRIGHT & AK & - & No & & & PAFB & & 26403 \\
\hline GEORGIA ARNG & GA & Southeast & No & Various & & & & \\
\hline GUAM ARNG (MOB) & Guam & & No & OCONUS & & & & \\
\hline HAWAII ARNG & $\mathrm{HI}$ & - & No & Various & & & & \\
\hline HAWTHORNE AAP (GOCO) & NV & Southwest & No & Industrial & & & & \\
\hline HOLSTON AAP (GOCO) & TN & Southeast & No & Industrial & & & & \\
\hline IDAHO ARNG & ID & Northwest & No & Various & & & & \\
\hline ILLINOIS ARNG & IL & Midwest & No & Various & & & & \\
\hline INDIANA ARNG & IN & Midwest & No & Various & & & & \\
\hline IOWA AAP (GOCO) & IA & Midwest & No & Industrial & & & & \\
\hline IOWA ARNG & IA & Midwest & No & Various & & & & \\
\hline JOINT BASE LEWIS MCCHORD & WA & Northwest & Yes & & Gray AAF Airport & KGRF & 74207 & 24201 \\
\hline $\begin{array}{l}\text { JOINT BASE MYER- } \\
\text { HENDERSON HALL }\end{array}$ & VA & Southeast & Yes & & $\begin{array}{l}\text { Ronald Reagan } \\
\text { Washington Natl AP }\end{array}$ & $\mathrm{KDCA}$ & & \\
\hline KANSAS ARNG & KS & $\begin{array}{l}\text { S. Great } \\
\text { Plains }\end{array}$ & No & Various & & & & \\
\hline KENTUCKY ARNG & KY & Southeast & No & Various & & & & \\
\hline KWAJALEIN ATOLL & Kwajalein & & No & OCONUS & & & & \\
\hline LAKE CITY AAP (GOCO) & MO & Midwest & No & Industrial & & & & \\
\hline LETTERKENNY ARMY DEPOT & PA & Northeast & No & Industrial & & & & \\
\hline LIMA JSMC & $\mathrm{OH}$ & Midwest & No & Industrial & & & & \\
\hline LOUISIANA ARNG & LA & Southeast & No & Various & & & & \\
\hline MAINE ARNG & ME & Northeast & No & Various & & & & \\
\hline MARYLAND ARNG & MD & Northeast & No & Various & & & & \\
\hline MASSACHUSETTS ARNG & MA & Northeast & No & Various & & & & \\
\hline MCALESTER AAP & OK & $\begin{array}{l}\text { S. Great } \\
\text { Plains }\end{array}$ & No & Industrial & & & & \\
\hline MICHIGAN ARNG & Ml & Midwest & No & Various & & & & \\
\hline MILAN AAP (GOCO) & TN & Southeast & No & Industrial & & & & \\
\hline $\begin{array}{l}\text { MILITARY OCEAN TML } \\
\text { CONCORD }\end{array}$ & $\mathrm{CA}$ & Southwest & No & Industrial & & & & \\
\hline MINNESOTA ARNG & MN & Midwest & No & Various & & & & \\
\hline MISSISSIPPI ARNG & MS & Southeast & No & Various & & & & \\
\hline MISSOURI ARNG & MO & Midwest & No & Various & & & & \\
\hline MONTANA ARNG & MT & $\begin{array}{l}\text { N. Great } \\
\text { Plains } \\
\end{array}$ & No & Various & & & & \\
\hline MOT SUNNY POINT & NC & Southeast & No & Industrial & & & & \\
\hline NEBRASKA ARNG & $\mathrm{NE}$ & $\begin{array}{l}\text { S. Great } \\
\text { Plains }\end{array}$ & No & Various & & & & \\
\hline NEVADA ARNG & NV & Southwest & No & Various & & & & \\
\hline NEW HAMPSHIRE ARNG & $\mathrm{NH}$ & Northeast & No & Various & & & & \\
\hline
\end{tabular}




\begin{tabular}{|c|c|c|c|c|c|c|c|c|}
\hline Installation & Location & $\begin{array}{l}\text { CONUS Re- } \\
\text { gion }\end{array}$ & $\begin{array}{l}\text { Suitable for } \\
\text { Analysis }\end{array}$ & $\begin{array}{l}\text { Com- } \\
\text { ment }\end{array}$ & Station Name & $\begin{array}{l}\text { ICAO } \\
\text { Codes } \\
\end{array}$ & $\begin{array}{l}\text { WMO } \\
\text { Codes }\end{array}$ & $\begin{array}{l}\text { WBAN } \\
\text { Code }\end{array}$ \\
\hline NEW JERSEY ARNG & NJ & Northeast & No & Various & & & & \\
\hline NEW MEXICO ARNG & NM & Southwest & No & Various & & & & \\
\hline NEW YORK ARNG & NY & Northeast & No & Various & & & & \\
\hline NORTH CAROLINA ARNG & NC & Southeast & No & Various & & & & \\
\hline NORTH DAKOTA ARNG & ND & $\begin{array}{l}\text { N. Great } \\
\text { Plains }\end{array}$ & No & Various & & & & \\
\hline OHIO ARNG & $\mathrm{OH}$ & Midwest & No & Various & & & & \\
\hline OKLAHOMA ARNG & OK & $\begin{array}{l}\text { S. Great } \\
\text { Plains }\end{array}$ & No & Various & & & & \\
\hline OREGON ARNG & OR & Northwest & No & Various & & & & \\
\hline PARKS CSTC & $\mathrm{CA}$ & Southwest & Yes & & Oakland & KOAK & 72493 & 23230 \\
\hline PENNSYLVANIA ARNG & PA & Northeast & No & Various & & & & \\
\hline PICATINNY ARSENAL & NJ & Northeast & No & Industrial & & & & \\
\hline PINE BLUFF ARSENAL & AR & Southeast & No & Industrial & & & & \\
\hline PRESIDIO OF MONTEREY & $\mathrm{CA}$ & Southwest & Yes & & $\begin{array}{l}\text { Monterey Peninsula } \\
\text { Airport }\end{array}$ & KMRY & & 23259 \\
\hline PUEBLO CHEMICAL DEPOT & $\mathrm{CO}$ & Southwest & No & Industrial & & & & \\
\hline PUERTO RICO ARNG (MOB) & $\begin{array}{c}\text { Puerto } \\
\text { Rico }\end{array}$ & & No & OCONUS & & & & \\
\hline RADFORD AAP (GOCO) & VA & Southeast & No & Industrial & & & & \\
\hline RED RIVER DEPOT & $\mathrm{TX}$ & $\begin{array}{l}\text { S. Great } \\
\text { Plains }\end{array}$ & No & Industrial & & & & \\
\hline REDSTONE ARSENAL & $\mathrm{AL}$ & Southeast & No & Industrial & & & & \\
\hline RHODE ISLAND ARNG & $\mathrm{RI}$ & Northeast & No & & & & & \\
\hline ROCK ISLAND ARSENAL & $\mathrm{IL}$ & Midwest & No & Industrial & & & & \\
\hline SCRANTON AAP & PA & Northeast & No & Industrial & & & & \\
\hline SIERRA ARMY DEPOT & $\mathrm{CA}$ & Southwest & No & Industrial & & & & \\
\hline $\begin{array}{l}\text { SOLDIER SYSTEMS CTR, } \\
\text { NATICK }\end{array}$ & MA & Northeast & No & Lab & & & & \\
\hline SOUTH CAROLINA ARNG & SC & Southeast & No & Various & & & & \\
\hline SOUTH DAKOTA ARNG & SD & $\begin{array}{l}\text { N. Great } \\
\text { Plains } \\
\end{array}$ & No & Various & & & & \\
\hline TENNESSEE ARNG & TN & Southeast & No & Various & & & & \\
\hline TEXAS ARNG & $\mathrm{TX}$ & $\begin{array}{l}\text { S. Great } \\
\text { Plains }\end{array}$ & No & Various & & & & \\
\hline TOBYHANNA ARMY DEPOT & PA & Northeast & No & Industrial & & & & \\
\hline TOOELE ARMY DEPOT & UT & Southwest & No & Industrial & & & & \\
\hline USAG ANSBACH & Germany & & No & OCONUS & & & & \\
\hline USAG BAVARIA & Germany & & No & OCONUS & & & & \\
\hline USAG BENELUX & Germany & & No & OCONUS & & & & \\
\hline USAG DAEGU & Korea & & No & OCONUS & & & & \\
\hline USAG DETROIT ARSENAL & $\mathrm{Ml}$ & Midwest & No & Industrial & & & & \\
\hline USAG HAWAII & $\mathrm{HI}$ & - & No & OCONUS & & & & \\
\hline USAG HUMPHREYS & Korea & & No & OCONUS & & & & \\
\hline
\end{tabular}




\begin{tabular}{|c|c|c|c|c|c|c|c|c|}
\hline Installation & Location & $\begin{array}{l}\text { CONUS Re- } \\
\text { gion }\end{array}$ & $\begin{array}{l}\text { Suitable for } \\
\text { Analysis }\end{array}$ & $\begin{array}{l}\text { Com- } \\
\text { ment }\end{array}$ & Station Name & $\begin{array}{l}\text { ICAO } \\
\text { Codes }\end{array}$ & $\begin{array}{l}\text { WMO } \\
\text { Codes }\end{array}$ & $\begin{array}{l}\text { WBAN } \\
\text { Code }\end{array}$ \\
\hline USAG MIAMI & $\mathrm{FL}$ & Southeast & Yes & & $\begin{array}{l}\text { Miami International } \\
\text { Airport }\end{array}$ & KMIA & 72202 & 12839 \\
\hline USAG RED CLOUD & Korea & & No & OCONUS & & & & \\
\hline USAG REHEINLAND-PFALZ & Germany & & No & OCONUS & & & & \\
\hline USAG STUTTGART & Germany & & No & OCONUS & & & & \\
\hline USAG VICENZA & Italy & & No & OCONUS & & & & \\
\hline USAG WIESBADEN & Germany & & No & OCONUS & & & & \\
\hline USAG YONGSAN & Korea & & No & OCONUS & & & & \\
\hline UTAH ARNG & UT & Southwest & No & Various & & & & \\
\hline VERMONT ARNG & VT & Northeast & No & Various & & & & \\
\hline VIRGINA ISLANDS ARNG (MOB) & $\begin{array}{l}\text { Virgin Is- } \\
\text { lands }\end{array}$ & & No & OCONUS & & & & \\
\hline VIRGINIA ARNG & VA & Southeast & No & & & & & \\
\hline WASHINGTON ARNG & WA & Northwest & No & Various & & & & \\
\hline WATERVLIET ARSENAL & NY & Northeast & No & Industrial & & & & \\
\hline $\begin{array}{l}\text { WEST POINT MIL } \\
\text { RESERVATION }\end{array}$ & NY & Northeast & Yes & & $\begin{array}{l}\text { Stewart International } \\
\text { Airport }\end{array}$ & KSWF & 99999 & 14714 \\
\hline WEST VIRGINA ARNG & WV & Northeast & No & Various & & & & \\
\hline WHITE SANDS MISSILE RANGE & NM & Southwest & No & Industrial & & & & \\
\hline WISCONSIN ARNG & WI & Midwest & No & Various & & & & \\
\hline WYOMING ARNG & WY & $\begin{array}{l}\text { N. Great } \\
\text { Plains }\end{array}$ & No & Various & & & & \\
\hline YUMA PROVING GROUND & $A Z$ & Southwest & No & Industrial & & & & \\
\hline
\end{tabular}




\section{Appendix C: Accessing Historic GSOD Weather Data}

To access GSOD data for a location of interest, follow the procedure outlined below.

Access the NNDC CLIMATE DATA ONLINE website at http://www7.ncdc.noaa.gov/CDO/cdoselect.cmd?datasetabbv=GSOD\&resolution=40

2. On this site, select the Country (United States) and click "Continue".

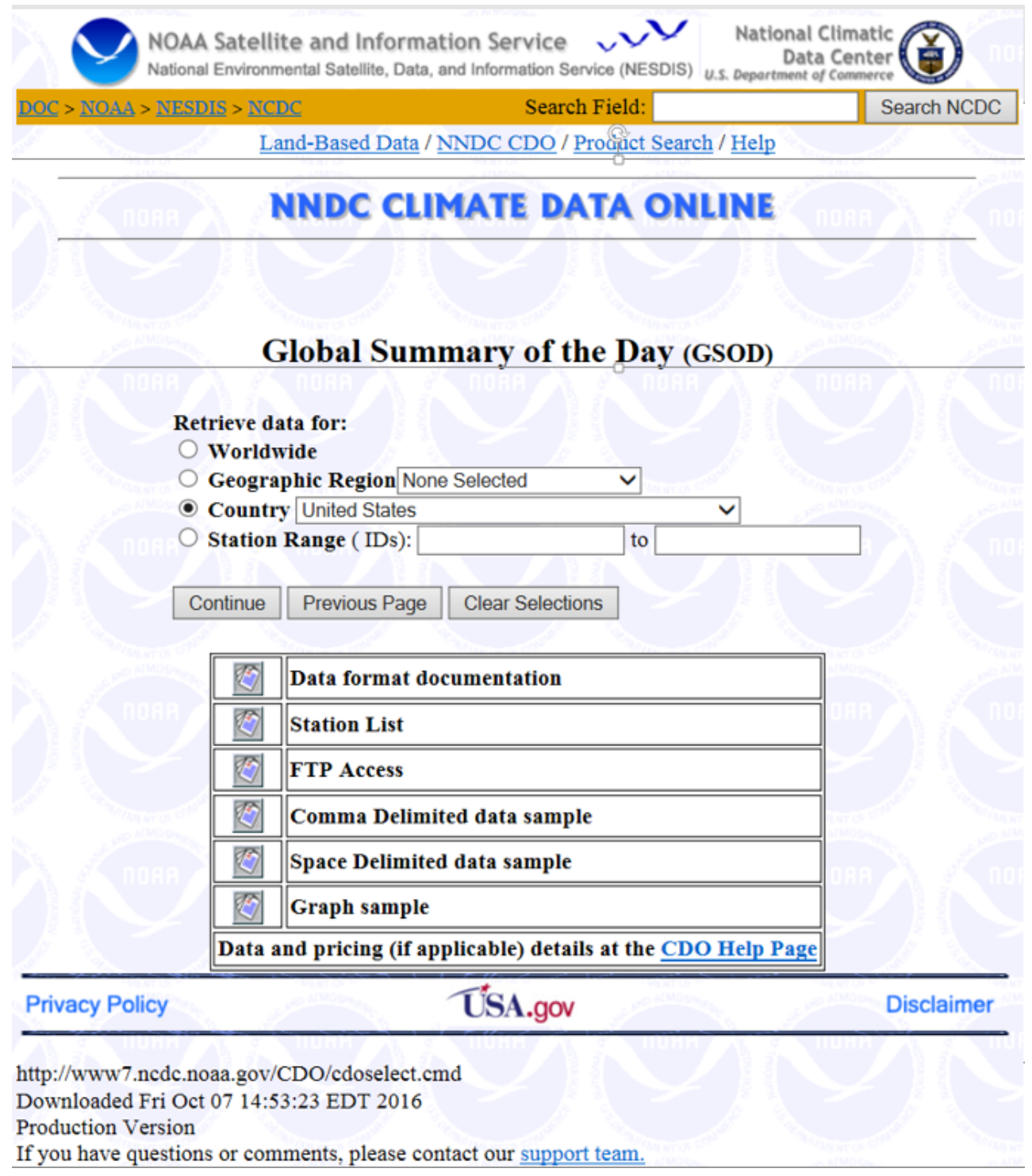


3. On the next page, select the State of interest from the drop down box, click the radio button for "Selected Stations in the state", then click "Continue".

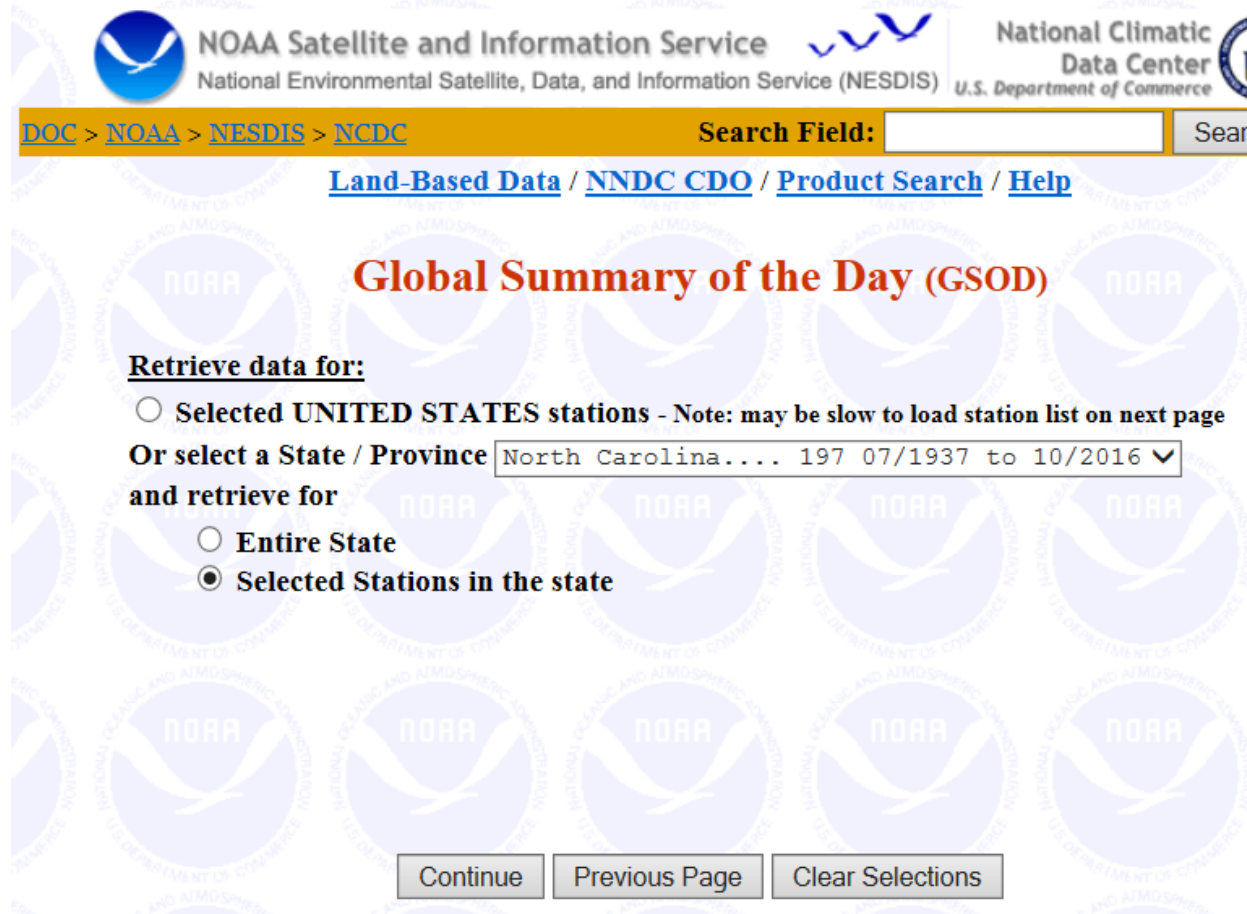

Privacy Policy

Úts.gov

Disclaimer

http://www7.ncdc.noaa.gov/CDO/cdogetsubquery.cmd

Downloaded Fri Oct 07 15:21:53 EDT 2016

Production Version

If you have questions or comments, please contact our support team. 


\section{Select the station and click "Continue".}

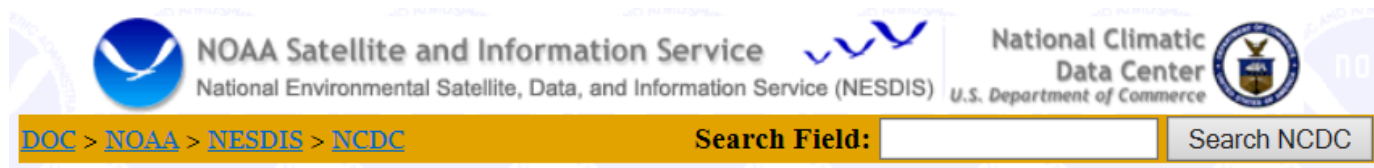

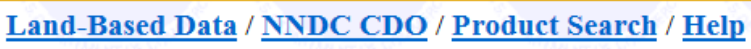

Global Summary of the Day (GSOD)

Selected NORTH CAROLINA stations - Note: may be slow to load station list on next page Select Stations:

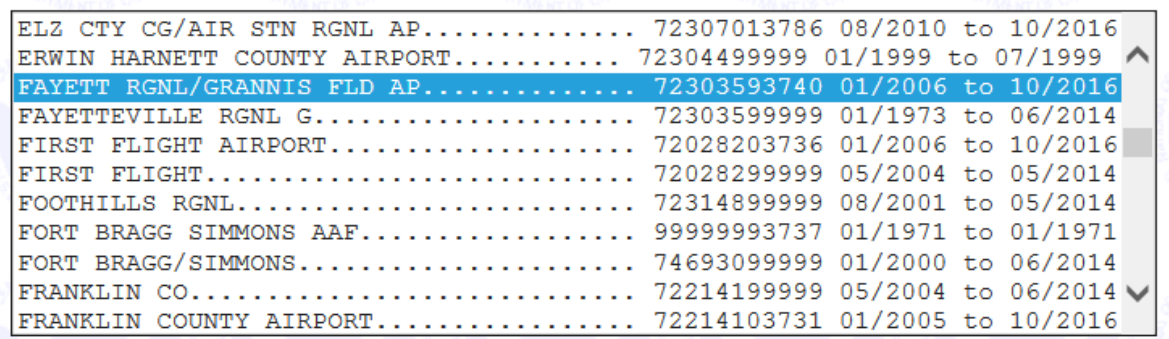

Order by Station ID - Order by Station Name

Continue Previous Page Clear Selections

\section{Selecting Multiple Stations}

1. To select one station, just click on it.

2. To select multiple sequential stations, click on the first station, scroll down to the last station, hold the Shift key down and click on the last station.

3. To select multiple non-sequential stations, click on the first station, then hold the Control key down while clicking on additional stations. To deselect a station, hold the Control key down while clicking on that station.

http://www7.ncdc.noaa.gov/CDO/cdosubqueryrouter.cmd

Downloaded Fri Oct 07 15:23:13 EDT 2016

Production Version

If you have questions or comments, please contact our support team. 
5. Set the data range of time period and choose your desired output format (e.g., Comma Delimited"). Acknowledge the CDO challenge (I'm not a robot) and click "Continue".

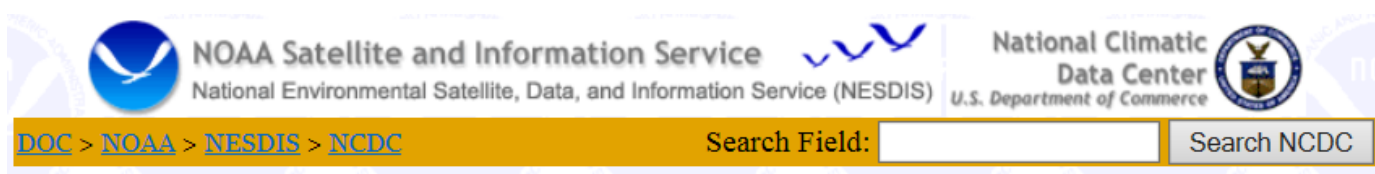

Land-Based Data / NNDC CDO / Product Search /

Global Summary of the Day (GSOD)

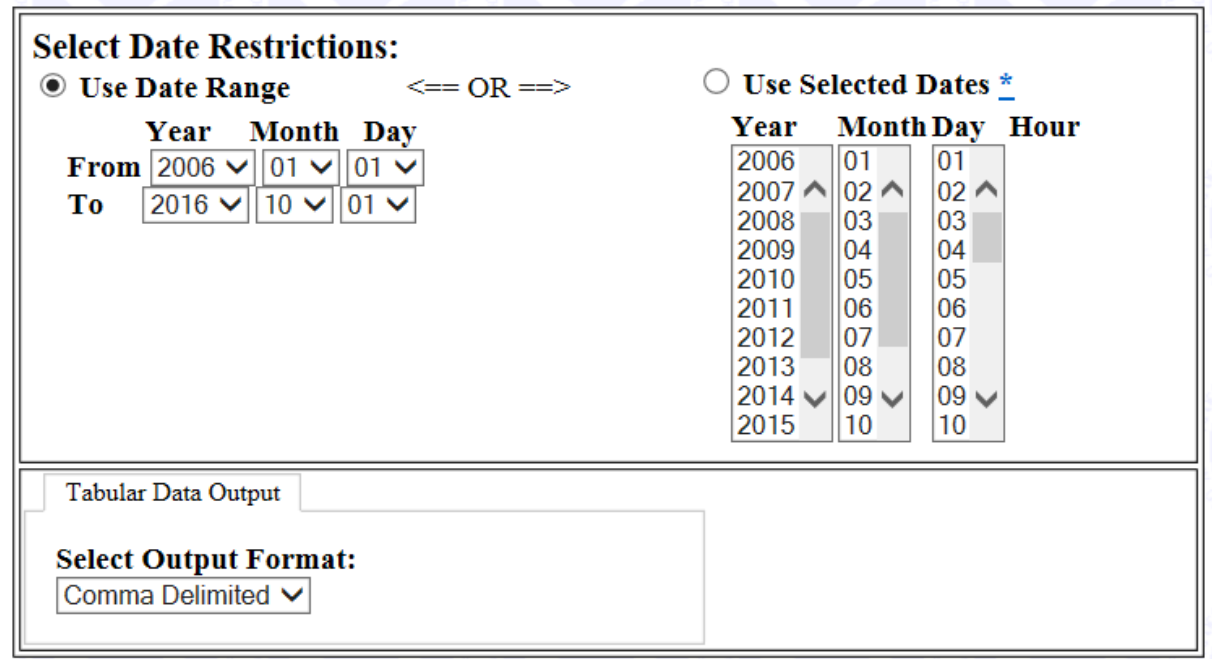

Acknowledge CDO challenge before continuing

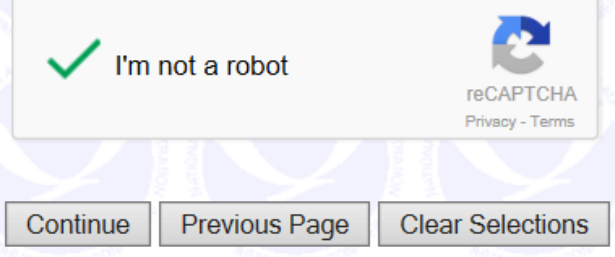

* Date List Notes:

Uses all combinations of selected year(s), month(s) and day(s). For example, selecting years of $(1993,1995)$, months of $(03,04)$, days of $(01,15)$ will result in Year/Month/Day date selections of (1993/03/01, 1993/03/15, 1993/04/01, 1993/04/15, 1995/03/01, 1995/03/15, 1995/04/01, 1995/04/15).

Return to Date List 


\section{Click on the .txt file to download it.}

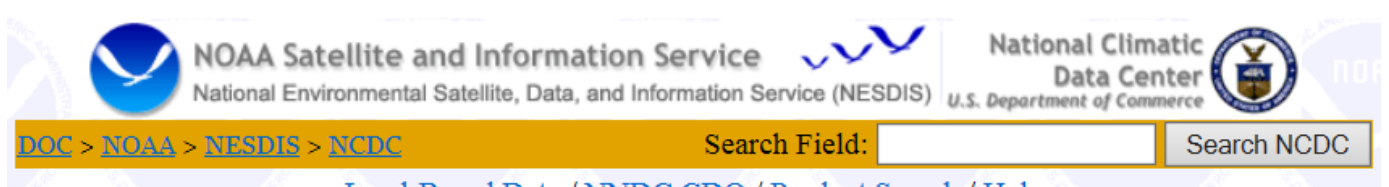

Land-Based Data / NNDC CDO / Product Search / $\underline{\text { Help }}$

\section{NNDC CLIMATE DATA ONLINE}

\section{Climate Data Online, Data Output}

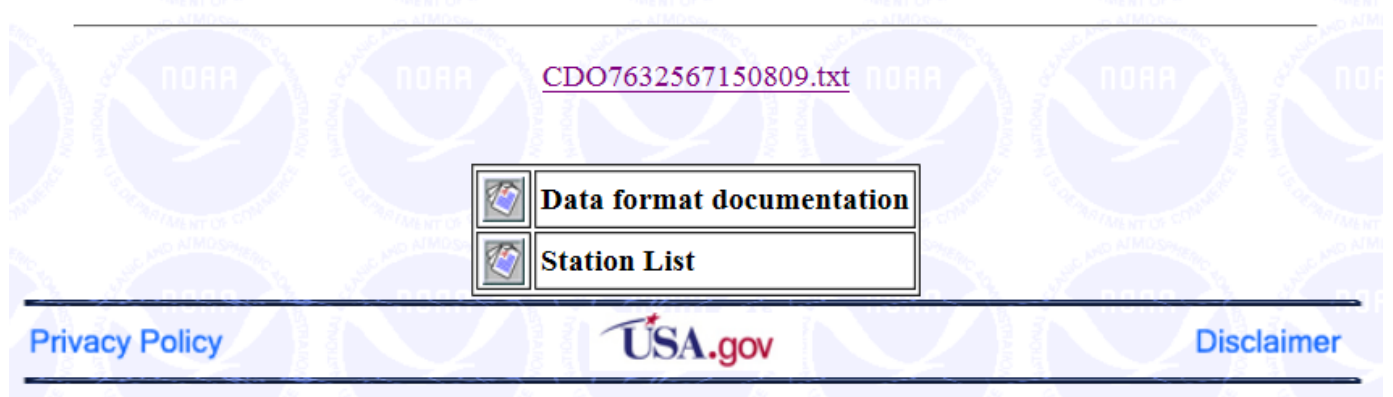

http://www7.ncdc.noaa.gov/CDO/cdodata.cmd

Downloaded Fri Oct 07 15:15:03 EDT 2016

Production Version

If you have questions or comments, please contact our support team.
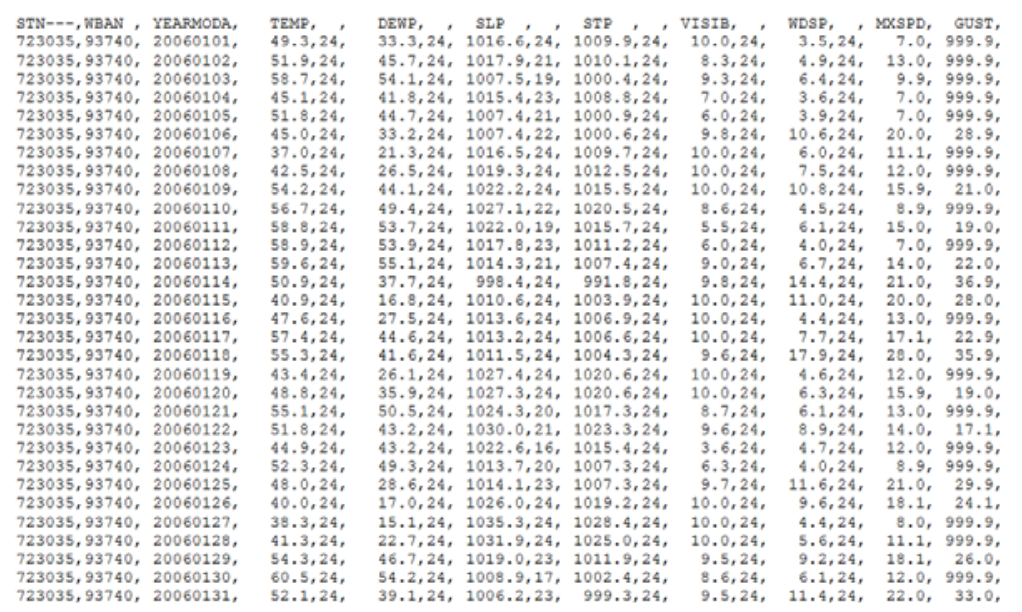

MAX, MTN, PRCP, SNDP, FRSHTT,

$63.0,33.1,0.000,999.9,000000$

$62.1,42.1,0.506,999.9,010000$

$62.1 ; 37.0 ; 0.056,999.9,000000$

$66.0 ; 36.0 ; 0.106,999.9,911000$

$50.0,26.1 ; 0.096,999.9,000000$

$60.1 ; 26.1 ; 0.006,999.9,000000$

$71.1,44.1,0.006,999.9,100000$

$72.0,43.0,0.136,999.9,110000$

$72.0,51.1,0.026,999.9,100000$

$72.0 ; 51.1,0.016,999.9,000000$

$71.1,43.0 ; 0.096,999.9,010000$

$64.9,30.9,0.006,999.9,000000$

$71.1,34.0,0.026,9999,010000$

$71.1,42.1,0.376,999.9,010000$

$70.0,28.9,0.001,999.9,000000$

$66.0,28,0.006,999.9,000000$

$69.80^{2}, 44.1 \%, 0.006,999.9,010000$

$60.1,41,0,0.056,999.9,110000$

$55.0,41.0,0.506,999.9,010000$

$55.0,37.0,0.206,999.9,000000$

$55.0,30.0,0.006,999.9,000000$

$51.1,26.1,0.006,999.9,000000$

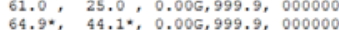

$66.9,42.1,0.006,999.9,010000$ $39.1,24,1006.2,23,999.3,24, \quad 9.5,24,11.4,24,22.0,33.0, \quad 66.9,44.1,0.166,999.9,010000$

\section{Open the .txt file using Excel.}




\section{Appendix D: Projected Climate Change Impacts on Installations' Energy Usage}

\section{Fort Bliss}

Figure D1. Fort Bliss historical characteristic EUI vs monthly average temperature curve based on 2014-2015 data.

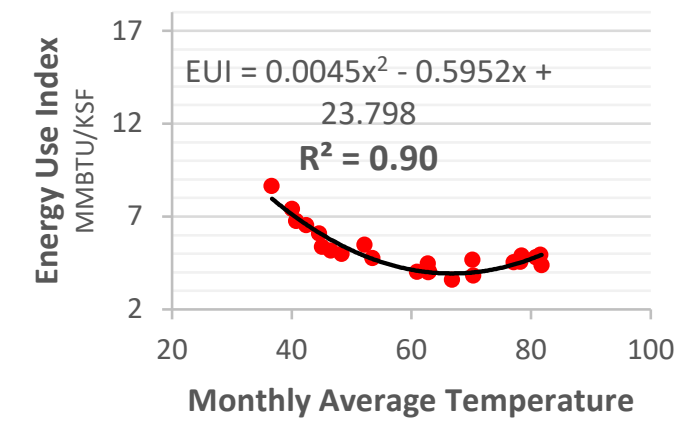

Table D1. Time series projections of Fort Bliss EUI.

\begin{tabular}{|c|c|c|c|c|c|c|c|}
\hline Fort Bliss & $\begin{array}{l}2020 \\
(2018- \\
2022)\end{array}$ & $\begin{array}{l}2025 \\
(2023- \\
2027)\end{array}$ & $\begin{array}{l}2030 \\
(2028- \\
2032)\end{array}$ & $\begin{array}{l}2035 \\
(2033- \\
2037)\end{array}$ & $\begin{array}{l}2040 \\
(2038- \\
2042)\end{array}$ & $\begin{array}{l}2045 \\
(2043- \\
2047)\end{array}$ & $\begin{array}{l}2050 \\
(2048- \\
2052)\end{array}$ \\
\hline Annual EUI (Upper Bound) & 60.5 & 60.2 & 60.2 & 61.2 & 61.4 & 61.0 & 60.4 \\
\hline MEAN Annual EUI & 60.2 & 59.6 & 60.2 & 60.5 & 60.6 & 60.5 & 60.1 \\
\hline Annual EUI (Lower Bound) & 60.0 & 59.2 & 60.2 & 59.8 & 59.8 & 60.0 & 59.8 \\
\hline
\end{tabular}

Figure D2. Time series plot of projected Fort Bliss EUI from 2020 to 2050.

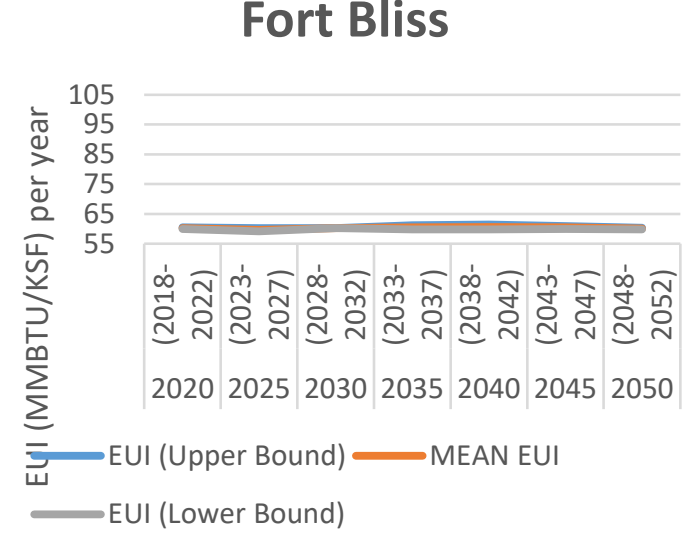




\section{Fort Bragg}

Figure D3. Fort Bragg historical characteristic monthly EUI vs monthly average temperature curve based on 2014-2015 data.

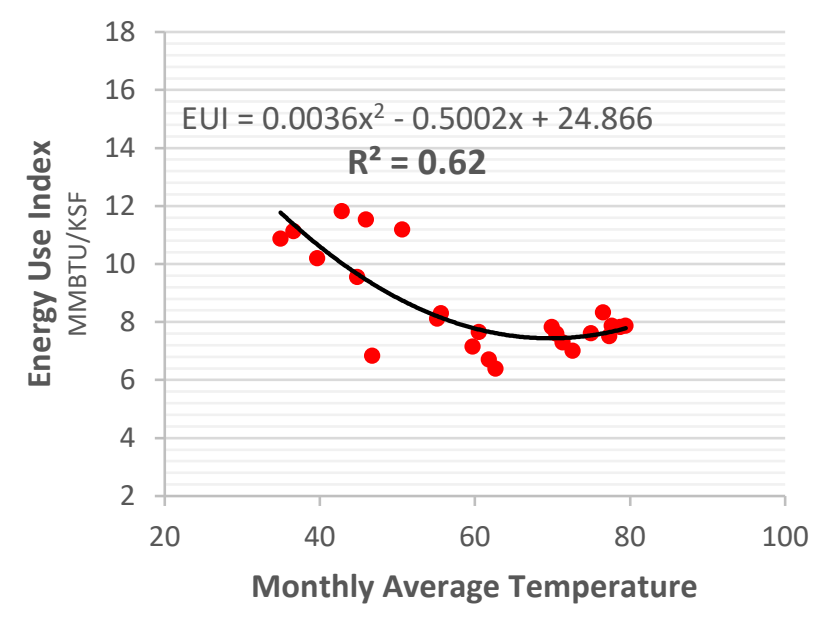

Table D2. Time series projections of Fort Bragg EUI.

\begin{tabular}{|c|c|c|c|c|c|c|c|}
\hline Fort Bragg & $\begin{array}{l}2020 \\
(2018- \\
2022)\end{array}$ & $\begin{array}{l}2025 \\
(2023- \\
2027)\end{array}$ & $\begin{array}{l}2030 \\
(2028- \\
2032)\end{array}$ & $\begin{array}{l}2035 \\
(2033- \\
2037)\end{array}$ & $\begin{array}{l}2040 \\
(2038- \\
2042)\end{array}$ & $\begin{array}{l}2045 \\
(2043- \\
2047)\end{array}$ & $\begin{array}{l}2050 \\
(2048- \\
2052)\end{array}$ \\
\hline Annual EUI (Upper Bound) & 100.1 & 99.5 & 99.0 & 100.2 & 98.6 & 99.4 & 99.2 \\
\hline MEAN Annual EUI & 99.1 & 99.5 & 98.9 & 100.2 & 98.4 & 99.1 & 99.0 \\
\hline Annual EUI (Lower Bound) & 98.0 & 99.4 & 98.9 & 100.2 & 98.0 & 98.9 & 98.8 \\
\hline
\end{tabular}

Figure D4. Time series plot of projected Fort Bragg EUI from 2020 to 2050.

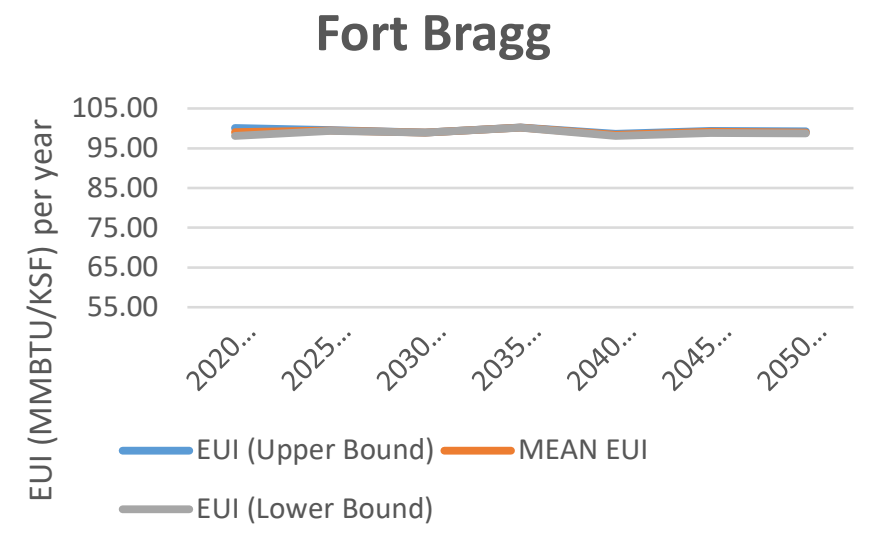




\section{Fort Carson}

Figure D5. Fort Carson historic characteristic monthly EUI vs monthly average temperature curve based on 2014-2015 data.

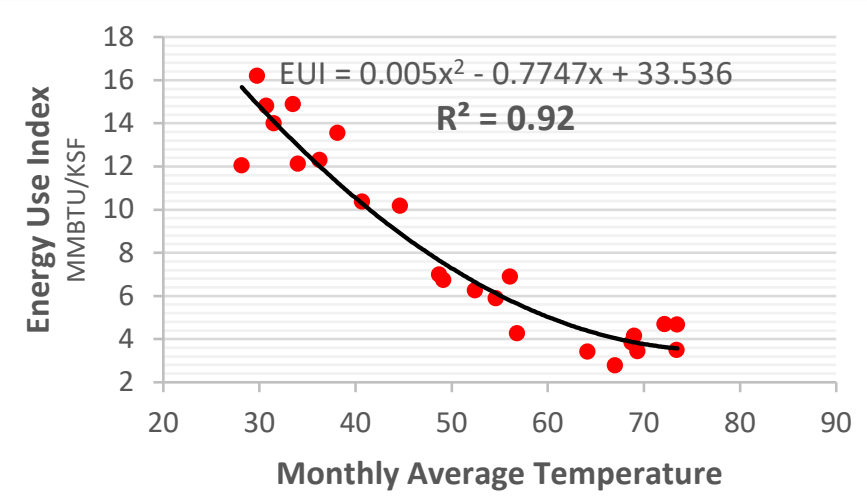

Table D3. Time series projections of Fort Carson EUI.

\begin{tabular}{|c|c|c|c|c|c|c|c|}
\hline Fort Carson & $\begin{array}{l}2020 \\
(2018- \\
2022)\end{array}$ & $\begin{array}{l}2025 \\
(2023- \\
2027)\end{array}$ & $\begin{array}{l}2030 \\
(2028- \\
2032)\end{array}$ & $\begin{array}{l}2035 \\
(2033- \\
2037)\end{array}$ & $\begin{array}{l}2040 \\
(2038- \\
2042)\end{array}$ & $\begin{array}{l}2045 \\
(2043- \\
2047)\end{array}$ & $\begin{array}{l}2050 \\
(2048- \\
2052)\end{array}$ \\
\hline Annual EUI (Upper Bound) & 92.9 & 100.0 & 93.0 & 93.2 & 91.9 & 93.2 & 87.6 \\
\hline MEAN Annual EUI & 91.9 & 93.5 & 90.5 & 92.0 & 91.4 & 91.2 & 87.4 \\
\hline Annual EUI (Lower Bound) & 91.1 & 86.9 & 87.8 & 91.0 & 91.0 & 89.2 & 87.1 \\
\hline
\end{tabular}

Figure D6. Time series plot of projected Fort Carson EUI from 2020 to 2050.

\section{Fort Carson}

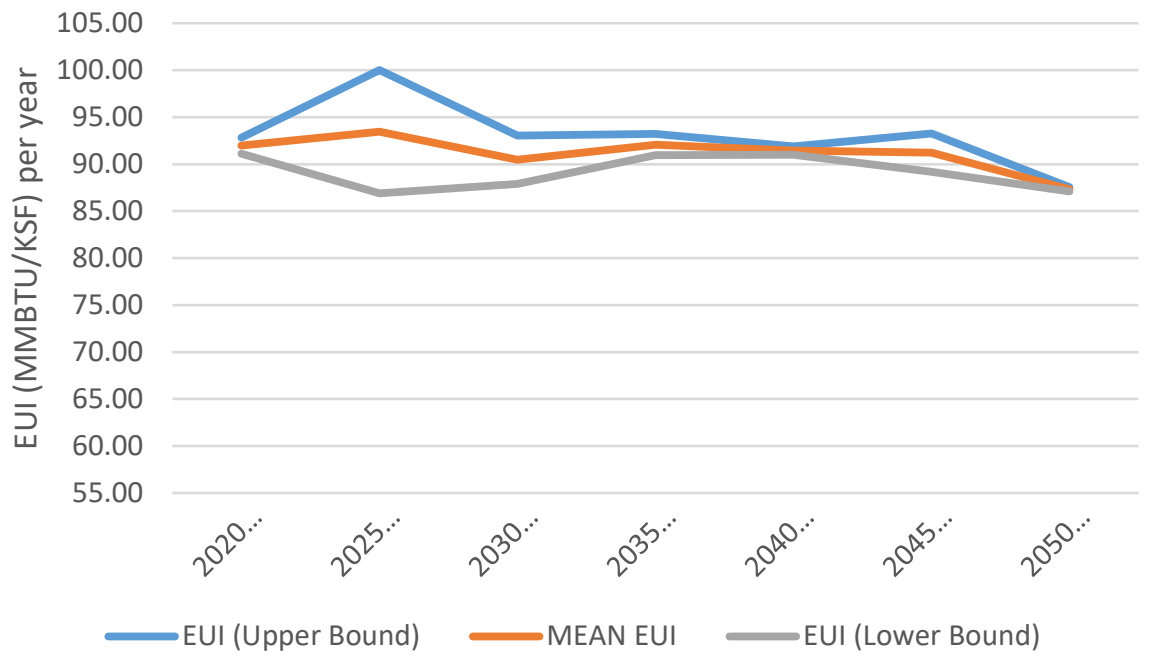




\section{Fort Riley}

Figure D7. Fort Riley historical characteristic monthly EUI vs monthly average temperature curve based on 2014-2015 data.

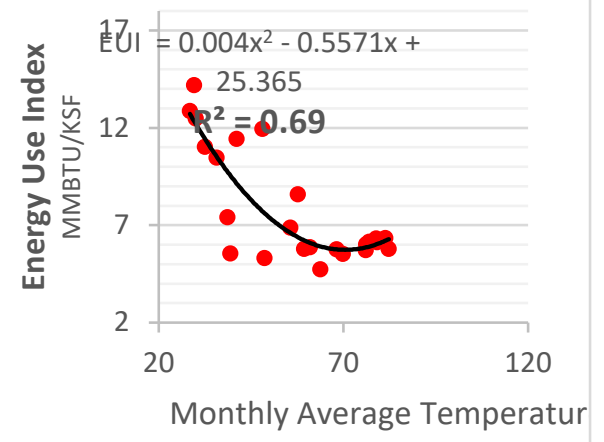

Table D4. Time series projections of Fort Riley EUI.

\begin{tabular}{|c|c|c|c|c|c|c|c|}
\hline Fort Riley & $\begin{array}{l}2020 \\
(2018- \\
2022)\end{array}$ & $\begin{array}{l}2025 \\
(2023- \\
2027)\end{array}$ & $\begin{array}{l}2030 \\
(2028- \\
2032)\end{array}$ & $\begin{array}{l}2035 \\
(2033- \\
2037)\end{array}$ & $\begin{array}{l}2040 \\
(2038- \\
2042)\end{array}$ & $\begin{array}{l}2045 \\
(2043- \\
2047)\end{array}$ & $\begin{array}{l}2050 \\
(2048- \\
2052)\end{array}$ \\
\hline Annual EUI (Upper Bound) & 94.6 & 95.3 & 93.7 & 96.1 & 94.6 & 95.6 & 94.1 \\
\hline MEAN Annual EUI & 93.8 & 94.7 & 93.4 & 95.0 & 92.4 & 94.0 & 92.0 \\
\hline Annual EUI (Lower Bound) & 93.1 & 94.2 & 92.9 & 94.0 & 90.2 & 92.4 & 90.1 \\
\hline
\end{tabular}

Figure D8. Time series plot of projected Fort Riley EUI from 2020 to 2050.

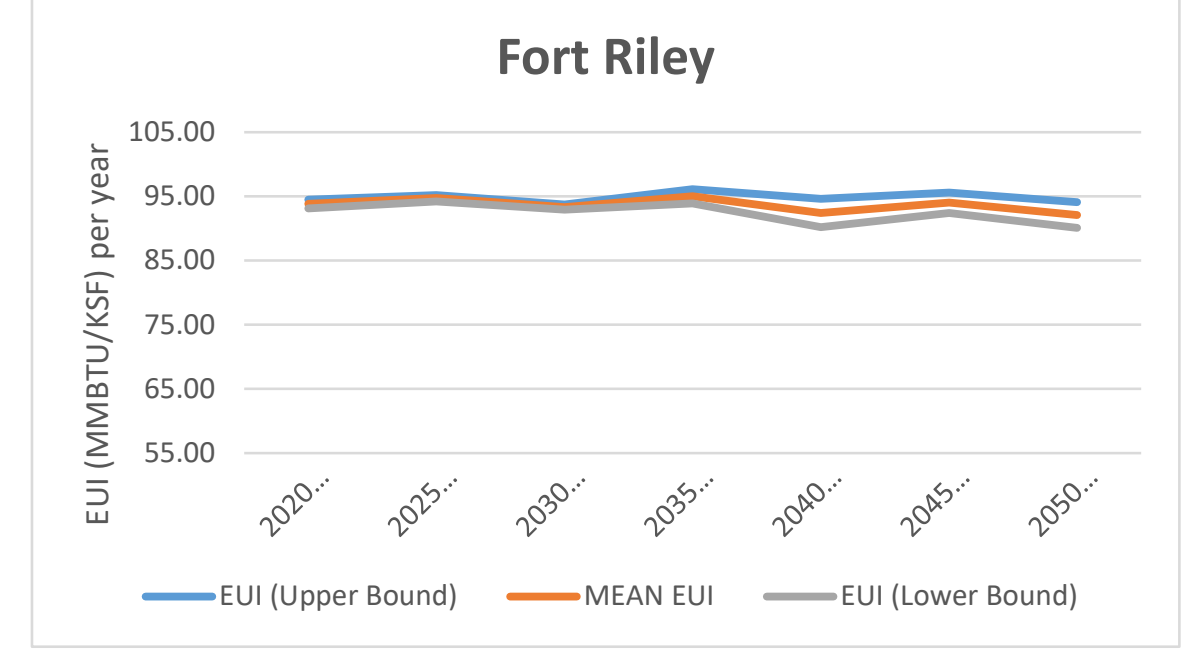




\section{Fort Sill}

Figure D9. Fort Sill historic characteristic monthly EUI vs monthly average temperature curve based on 2014-2015 data.

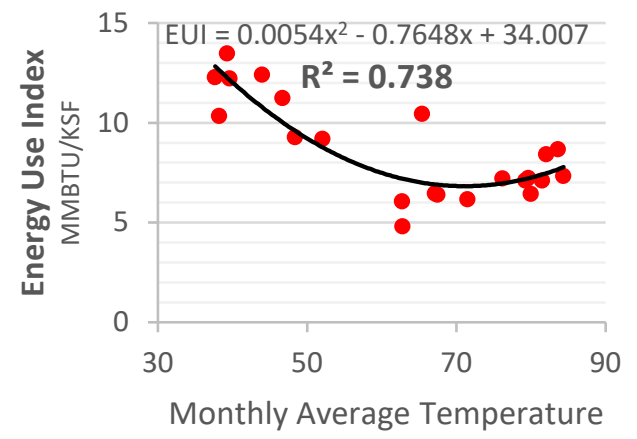

Table D5. Time series projections of Fort Sill EUI.

\begin{tabular}{|c|c|c|c|c|c|c|c|}
\hline Fort Sill & $\begin{array}{l}2020 \\
(2018- \\
2022)\end{array}$ & $\begin{array}{l}2025 \\
(2023- \\
2027)\end{array}$ & $\begin{array}{l}2030 \\
(2028- \\
2032)\end{array}$ & $\begin{array}{l}2035 \\
(2033- \\
2037)\end{array}$ & $\begin{array}{l}2040 \\
(2038- \\
2042)\end{array}$ & $\begin{array}{l}2045 \\
(2043- \\
2047)\end{array}$ & $\begin{array}{l}2050 \\
(2048- \\
2052)\end{array}$ \\
\hline Annual EUI (Upper Bound) & 102.2 & 102.5 & 101.8 & 103.3 & 103.1 & 103.1 & 101.6 \\
\hline MEAN Annual EUI & 101.6 & 102.0 & 101.3 & 102.8 & 101.6 & 101.9 & 100.7 \\
\hline Annual EUI (Lower Bound) & 100.9 & 101.4 & 100.8 & 102.5 & 100.1 & 100.7 & 99.7 \\
\hline
\end{tabular}

Figure D10. Time series plot of projected Fort Sill EUI from 2020 to 2050.

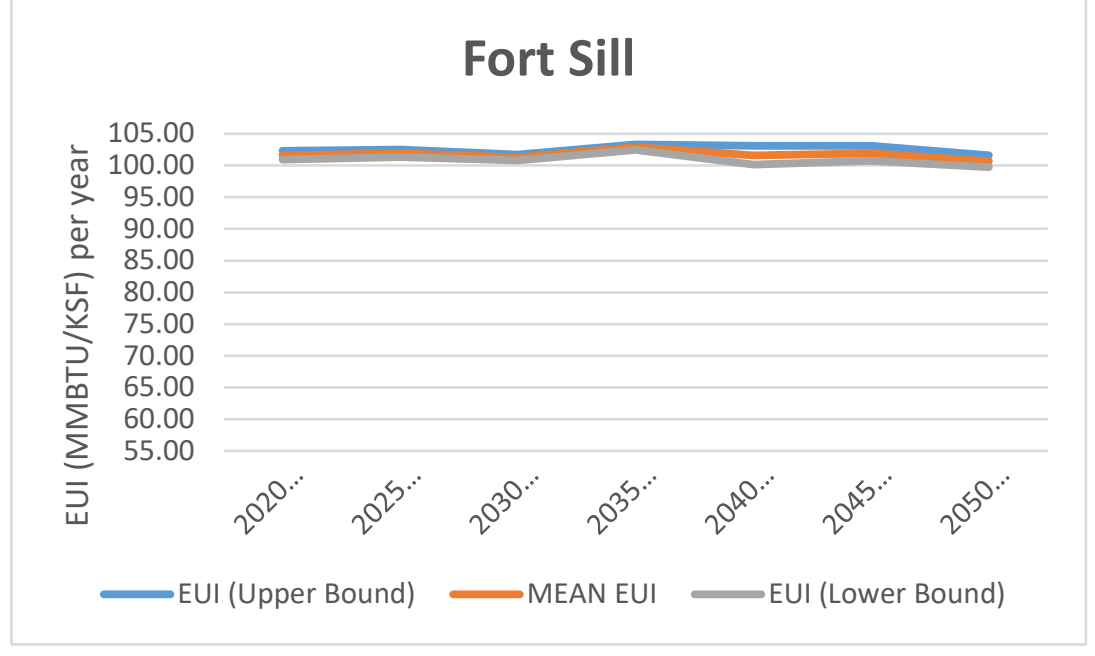


Table D6. Annual EUI projections for five installations, 2020 through 2030.

\begin{tabular}{|l|l|l|l|l|l|l|l|l|l|}
\hline & \multicolumn{2}{|l|}{2020} & \multicolumn{2}{l|}{2025} & \multicolumn{2}{l|}{2030} & \multicolumn{2}{l|}{} \\
& $\begin{array}{l}\text { Annual EUI } \\
\text { (Upper } \\
\text { Bound) }\end{array}$ & $\begin{array}{l}\text { Mean } \\
\text { Annual } \\
\text { EUI }\end{array}$ & $\begin{array}{l}\text { Annual } \\
\text { EUI } \\
\text { (Lower } \\
\text { Bound) }\end{array}$ & $\begin{array}{l}\text { Annual EUI } \\
\text { (Upper } \\
\text { Bound) }\end{array}$ & $\begin{array}{l}\text { Mean } \\
\text { Annual } \\
\text { EUI }\end{array}$ & $\begin{array}{l}\text { Annual } \\
\text { EUI } \\
\text { (Lower } \\
\text { Bound) }\end{array}$ & $\begin{array}{l}\text { Annual EUI } \\
\text { (Upper } \\
\text { Bound) }\end{array}$ & $\begin{array}{l}\text { Mean } \\
\text { Annual } \\
\text { EUI }\end{array}$ & $\begin{array}{l}\text { Annual } \\
\text { EUI } \\
\text { (Lower } \\
\text { Bound) }\end{array}$ \\
\hline Fort Bliss & 60.48 & 60.24 & 60 & 60.24 & 59.64 & 59.16 & 60.24 & 60.24 & 60.24 \\
\hline Fort Bragg & 100.08 & 99.12 & 98.04 & 99.48 & 99.48 & 99.36 & 99 & 98.88 & 98.88 \\
\hline Fort Carson & 92.88 & 91.92 & 91.08 & 99.96 & 93.48 & 86.88 & 93 & 90.48 & 87.84 \\
\hline Fort Riley & 94.56 & 93.84 & 93.12 & 95.28 & 94.68 & 94.2 & 93.72 & 93.36 & 92.88 \\
\hline Fort Sill & 102.24 & 101.64 & 100.92 & 102.48 & 102 & 101.4 & 101.76 & 101.28 & 100.8 \\
\hline
\end{tabular}

Table D7. Annual EUI projections for five installations, 2035 through 2045.

\begin{tabular}{|l|l|l|l|l|l|l|l|l|l|l|}
\hline & 2035 & \multicolumn{3}{|l|}{2040} & \multicolumn{2}{l|}{2045} \\
\hline & $\begin{array}{l}\text { Annual EUI } \\
\text { (Upper } \\
\text { Bound) }\end{array}$ & $\begin{array}{l}\text { Mean } \\
\text { Annual } \\
\text { EUI }\end{array}$ & $\begin{array}{l}\text { Annual } \\
\text { EUI } \\
\text { (Lower } \\
\text { Bound) }\end{array}$ & $\begin{array}{l}\text { Annual EUI } \\
\text { (Upper } \\
\text { Bound) }\end{array}$ & $\begin{array}{l}\text { Mean } \\
\text { Annual } \\
\text { EUI }\end{array}$ & $\begin{array}{l}\text { Annual } \\
\text { EUI } \\
\text { Lower } \\
\text { Bound) }\end{array}$ & $\begin{array}{l}\text { Annual EUI } \\
\text { (Upper } \\
\text { Bound) }\end{array}$ & $\begin{array}{l}\text { Mean } \\
\text { Annual } \\
\text { EUI }\end{array}$ & $\begin{array}{l}\text { Annual } \\
\text { EUI } \\
\text { (Lower } \\
\text { Bound) }\end{array}$ \\
\hline Fort Bliss & 61.2 & 60.48 & 59.76 & 61.44 & 60.6 & 59.76 & 60.96 & 60.48 & 60 \\
\hline Fort Bragg & 100.2 & 100.2 & 100.2 & 98.64 & 98.4 & 98.04 & 99.36 & 99.12 & 98.88 \\
\hline Fort Carson & 93.24 & 92.04 & 90.96 & 91.92 & 91.44 & 90.96 & 93.24 & 91.2 & 89.16 \\
\hline Fort Riley & 96.12 & 95.04 & 93.96 & 94.56 & 92.4 & 90.24 & 95.64 & 93.96 & 92.4 \\
\hline Fort Sill & 103.32 & 102.84 & 102.48 & 103.08 & 101.64 & 100.08 & 103.08 & 101.88 & 100.68 \\
\hline
\end{tabular}

Table D8. Annual EUI projections for five installations for 2050.

\begin{tabular}{|c|c|c|c|}
\hline & \multicolumn{3}{|l|}{2050} \\
\hline & $\begin{array}{l}\text { Annual EUI (Upper } \\
\text { Bound) }\end{array}$ & $\begin{array}{l}\text { Mean Annual } \\
\text { EUI }\end{array}$ & $\begin{array}{l}\text { Annual EUI } \\
\text { (Lower Bound) }\end{array}$ \\
\hline Fort Bliss & 60.36 & 60.12 & 59.76 \\
\hline Fort Bragg & 99.24 & 99 & 98.76 \\
\hline Fort Carson & 87.6 & 87.36 & 87.12 \\
\hline Fort Riley & 94.08 & 92.04 & 90.12 \\
\hline Fort Sill & 101.64 & 100.68 & 99.72 \\
\hline
\end{tabular}




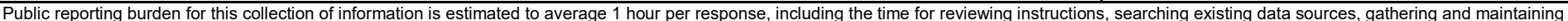

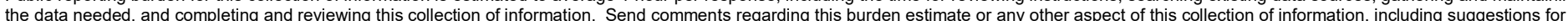

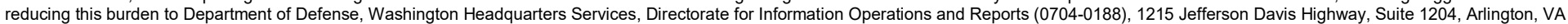

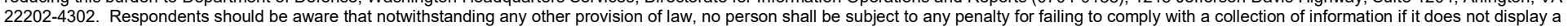
currently valid OMB control number. PLEASE DO NOT RETURN YOUR FORM TO THE ABOVE ADDRESS.
1. REPORT DATE (DD-MM-YYYY) 2. REPORT TYPE Final

June 2018

Projection of Climate-Change Impacts on Army Installation Energy Use

3. DATES COVERED (From - To)

5a. CONTRACT NUMBER

5b. GRANT NUMBER

5c. PROGRAM ELEMENT NUMBER

62272889600 A896

6. AUTHOR(S)

James P. Miller, Isabel H. Kim, and David M. Underwood

5d. PROJECT NUMBER

A1160-FY15; P2 402188

5e. TASK NUMBER

5f. WORK UNIT NUMBER

7. PERFORMING ORGANIZATION NAME(S) AND ADDRESS(ES)

U.S. Army Engineer Research and Development Center (ERDC)

Construction Engineering Research Laboratory (CERL)

8. PERFORMING ORGANIZATION REPORT NUMBER

PO Box 9005

Champaign, IL 61826-9005

ERDC/CERL TR-18-5

\section{SPONSORING / MONITORING AGENCY NAME(S) AND ADDRESS(ES)}

Office of the Assistant Secretary of the Army for Acquisition, Logistics, and Technology

103 Army Pentagon

Washington, DC 20314-1000

10. SPONSOR/MONITOR'S ACRONYM(S)

$\operatorname{ASA}(\mathrm{ALT})$

11. SPONSOR/MONITOR'S REPORT NUMBER(S)

\section{DISTRIBUTION / AVAILABILITY STATEMENT}

Approved for public release. Distribution is unlimited.

\section{SUPPLEMENTARY NOTES}

\section{ABSTRACT}

Army installations depend on a secure, reliable, and abundant supply of energy in order to accomplish their missions. As the range of Army activities has become increasingly complex, the Army's dependence on energy has grown accordingly. Simultaneously, the Army has experienced growing pressure to reduce its energy consumption. In addition, environmental concerns and federal mandates introduce added incentives to minimize installation energy consumption.

Because energy is such an essential support to the Army's mission and a significant element of the Army budget, when performing Army stationing analyses, it is appropriate to consider potential climate change implications on installations' energy usage.

This report documents research conducted from Fiscal Year 2014 (FY14), FY15, and FY16 that addresses how potential climate changes might affect Army installations from an energy perspective, with emphasis on how an installation's energy consumption might be projected to change as a result.

\section{SUBJECT TERMS}

Climatic changes-Risk assessment; Climatic changes-Forecasting; Military bases-United States; Energy consumption-Climatic factors

\begin{tabular}{|c|c|c|c|c|c|}
\hline \multicolumn{3}{|c|}{ 16. SECURITY CLASSIFICATION OF: } & \multirow{2}{*}{$\begin{array}{l}\text { 17. LIMITATION } \\
\text { OF ABSTRACT } \\
\text { UU }\end{array}$} & \multirow{2}{*}{$\begin{array}{l}\text { 18. NUMBER } \\
\text { OF PAGES } \\
100\end{array}$} & 19a. NAME OF RESPONSIBLE \\
\hline $\begin{array}{l}\text { a. REPORT } \\
\text { Unclassified }\end{array}$ & $\begin{array}{l}\text { b. ABSTRACT } \\
\text { Unclassified }\end{array}$ & $\begin{array}{l}\text { c. THIS PAGE } \\
\text { Unclassified }\end{array}$ & & & $\begin{array}{l}\text { 19b. TELEPHONE NUMBER } \\
\text { (include area code) }\end{array}$ \\
\hline
\end{tabular}

